\title{
Total Synthesis of the Proposed Structure of Maltepolide C
}

\author{
K. Nageswara Rao, ${ }^{\dagger}$ M. Kanakaraju, ${ }^{\ddagger}$ A. C. Kunwar, ${ }^{\ddagger}$ and Subhash Ghosh ${ }^{* \dagger}$ \\ ${ }^{\dagger}$ Organic and Biomolecular Chemistry Division and ${ }^{\ddagger}$ Centre for NMR \& Structural Chemistry, \\ CSIR-Indian Institute of Chemical Technology, Tarnaka, Hyderabad-500007, India \\ E-mail: $\underline{\text { subhash@iict.res.in }}$ \\ Fax: + 91-40-27191604; Tel: + 91-40-27191609;
}

\section{$\underline{\text { Table of Contents }}$}

I. General information and abbreviation

Page: S2

II. Experimental procedures and analytical data

Page: S3-S23

III. NMR and molecular dynamics (MD) studies of synthetic maltepolide C (3) Page: S23-S33

IV ${ }^{1} \mathrm{H}$ and ${ }^{13} \mathrm{C}$ NMR Spectra of 3, 7-9, 11, 13, 20-26, 29-34 and natural maltepolide $\mathrm{C}$

Page: S34-S74

V. 2D NMR data of compound 3

Page S75-S79 


\section{General information and abbreviations:}

\section{General information:}

All the air and moisture sensitive reactions were carried out under inert atmosphere (nitrogen or argon). Oven-dried glass apparatus were used to perform all the reactions. Freshly distilled anhydrous solvents were used for air and moisture sensitive reactions. Commercially available reagents were used as such. Purification of compounds was carried out via column chromatography by using silica gel (100-200 mesh) packed in glass columns. ${ }^{1} \mathrm{H}$ NMR and ${ }^{13} \mathrm{C}$ NMR were recorded in $\mathrm{CDCl}_{3}, \mathrm{C}_{6} \mathrm{D}_{6}$ and $\mathrm{CD}_{3} \mathrm{OD}$ solvents on $300 \mathrm{MHz}, 400 \mathrm{MHz}, 500 \mathrm{MHz}$, $600 \mathrm{MHz}, 700 \mathrm{MHz}$ and $75 \mathrm{MHz}, 100 \mathrm{MHz}, 125 \mathrm{MHz}, 150 \mathrm{MHz}, 175 \mathrm{MHz}$ spectrometer respectively, using TMS as an internal standard. Chemical shifts are measured as ppm values relative to internal $\mathrm{CHCl}_{3} \delta 7.26$ or TMS $\delta 0.0$ or $\mathrm{C}_{6} \mathrm{D}_{6} \delta 7.16, \mathrm{CD}_{3} \mathrm{OD} 3.31$ for ${ }^{1} \mathrm{H} \mathrm{NMR}$ and $\mathrm{CHCl}_{3} \delta 77, \mathrm{C}_{6} \mathrm{D}_{6} \delta 128.02, \mathrm{CD}_{3} \mathrm{OD} \delta 49.15$ for ${ }^{13} \mathrm{C}$ NMR. In ${ }^{1} \mathrm{H}$ NMR multiplicity defined as: $\mathrm{s}$ = singlet; $\mathrm{d}=$ doublet; $\mathrm{t}=$ triplet; $\mathrm{q}=$ quartet; quin= quintet, $\mathrm{dd}=$ doublet of doublet; $\mathrm{ddd}=$ doublet of doublet of doublet; dddd = doublet of doublet of doublet of doublet; $\mathrm{dt}=$ doublet of triplet; $\mathrm{td}=$ triplet of doublet; $\mathrm{qd}=$ quartet of doublet; $\mathrm{ddt}=$ doublet of doublet of triplet; $\mathrm{dtd}=$ doublet of triplet of doublet; tdd = triplet of doublet of doublet; dtd = doublet of triplet of doublet; $\mathrm{m}=$ multiplet; brs = broad singlet. Optical rotation values were recorded on Horiba sepa 300 polarimeter using a $2 \mathrm{~mL}$ cell with a $10 \mathrm{~mm}$ path length. FTIR spectra were recorded on Alpha (Bruker) infrared Spectrophotometer. High resolution mass spectra (HRMS) [ESI+] were obtained using either a TOF or a double focusing spectrometer.

\section{Abbreviations:}

KHMDS = Potassium bis(trimethylsilyl)amide; Ipc = Isopinocampheyl; DDQ = 2,3-Dichloro5,6-dicyano-1,4-benzoquinone; DMP = Dess-Martin periodinane; CSA = Camphorsulfonic acid; $\mathrm{THF}=$ Tetrahydrofuran $;$ DMAP $=4-($ Dimethylamino $)$ pyridine $;$ DMF $=$ Dimethylformamide. 


\section{Experimental procedures and analytical data:}

(5S,6S,E)-Ethyl 5-hydroxy-7-(4-methoxybenzyloxy)-6-methylhept-2-enoate (20):

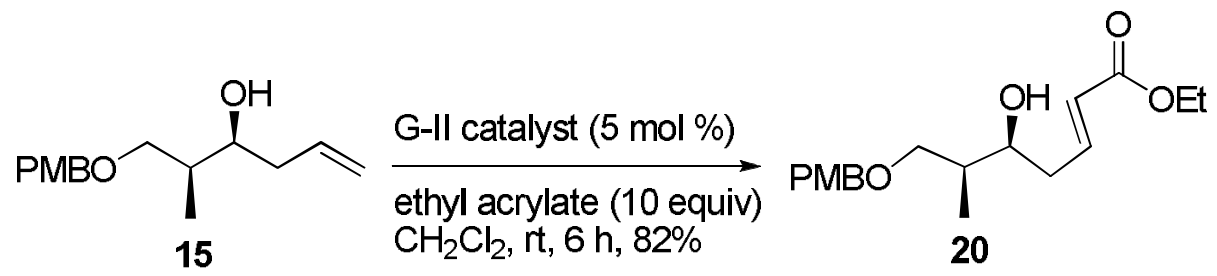

A solution of alcohol $15(1.65 \mathrm{~g}, 6.59 \mathrm{mmol})$ and ethyl acrylate $(7.16 \mathrm{ml}, 65.9 \mathrm{mmol})$ in anhydrous $\mathrm{CH}_{2} \mathrm{Cl}_{2}(76 \mathrm{ml})$ was degassed by purging argon for $15 \mathrm{~min}$ and then treated with G-II catalyst $(280 \mathrm{mg}, 0.33 \mathrm{mmol}, 5 \mathrm{~mol} \%)$. The resulting solution was stirred at room temperature under argon atmosphere for $6 \mathrm{~h}$. Then the catalyst was allowed to oxidize by opening the reaction to air and stirred for $1 \mathrm{~h}$. The dark brown solution was concentrated under reduced pressure to give crude material, which was purified by silica gel column chromatography $\left(\mathrm{SiO}_{2}\right.$, 100-200 mesh, 20\% EtOAc/hexane) to afford enoate 20 (1.75 g, $5.43 \mathrm{mmol}, 82 \%)$ as a pale yellow oil. $R_{f}=0.3\left(\mathrm{SiO}_{2}, 30 \% \mathrm{EtOAc} /\right.$ hexane $) ;[\alpha]_{\mathrm{D}}{ }^{25}=-15.8\left(c 1.23, \mathrm{CHCl}_{3}\right)$; IR $(\mathrm{Neat}): v_{\max }$ 3493, 2967, 2910, 2858, 1712, 1653, 1612, 1513, 1461, 1367, 1303, 1248, 1212, 1173, 1091, 1037, 982, 821, 709, $580 \mathrm{~cm}^{-1} ;{ }^{1} \mathrm{H}$ NMR (500 MHz, $\left.\mathrm{CDCl}_{3}\right): \delta 7.23(\mathrm{~m}, 2 \mathrm{H}), 6.98(\mathrm{td}, J=15.7$, $7.3 \mathrm{~Hz}, 1 \mathrm{H}), 6.88(\mathrm{~m}, 2 \mathrm{H}), 5.89(\mathrm{td}, J=15.7,1.4 \mathrm{~Hz}, 1 \mathrm{H}), 4.44(\mathrm{~d}, J=17.2 \mathrm{~Hz}, 1 \mathrm{H}), 4.43$ (d, $J=$ $17.2 \mathrm{~Hz}, 1 \mathrm{H}), 4.18(\mathrm{q}, J=7.1 \mathrm{~Hz}, 2 \mathrm{H}), 3.94-3.89$ (m, 1H), 3.81 (s, 3H), 3.53 (dd, $J=9.2,4.2 \mathrm{~Hz}$, 1H), 3.47 (dd, $J=9.2,6.3 \mathrm{~Hz}, 1 \mathrm{H}), 2.81$ (d, $J=4.0 \mathrm{~Hz}, 1 \mathrm{H}), 2.37$ (dddd, $J=18.5,14.5,7.5,1.5$ Hz, 1H), 2.29 (dddd, $J=14.5,6.4,4.8,1.5 \mathrm{~Hz}, 1 \mathrm{H}$ ), 1.92-1.86 (m, 1H), 1.28 (t, $J=7.2 \mathrm{~Hz}, 3 \mathrm{H})$, $0.94(\mathrm{~d}, J=7.0 \mathrm{~Hz}, 3 \mathrm{H}) ;{ }^{13} \mathrm{C} \mathrm{NMR}\left(100 \mathrm{MHz}, \mathrm{CDCl}_{3}\right): \delta 166.36,159.25,145.91,129.84$, 129.25, 123.26, 113.82, 74.08, 73.09, 72.87, 60.18, 55.22, 37.53, 36.95, 14.22, 10.69. HRMS (ESI): $[\mathrm{M}+\mathrm{Na}]^{+}$calcd. for $\mathrm{C}_{18} \mathrm{H}_{26} \mathrm{O}_{5} \mathrm{Na} 345.1673$, found 345.1681.

(2R,3S,5R)-Ethyl-3-hydroxy-5-((S)-1-(4-methoxybenzyloxy) propan-2-yl)tetrahydrofuran2-carboxylate (21): 


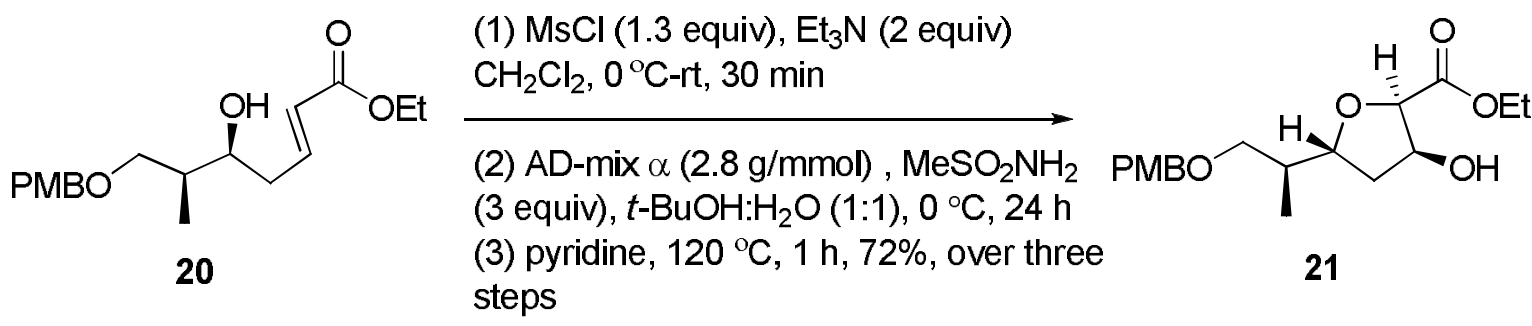

A solution of enoate $20(1.72 \mathrm{~g}, 5.33 \mathrm{mmol})$ in anhydrous $\mathrm{CH}_{2} \mathrm{Cl}_{2}(16 \mathrm{ml})$ were added $\mathrm{Et}_{3} \mathrm{~N}(1.48 \mathrm{ml}, 10.66 \mathrm{mmol})$ followed by $\mathrm{MsCl}(0.54 \mathrm{ml}, 6.93 \mathrm{mmol})$ at $0{ }^{\circ} \mathrm{C}$. The resulting solution was warmed to room temperature and stirred for $30 \mathrm{~min}$. After which time, TLC (20\% EtOAc/hexane) indicated the complete consumption of enoate 20. The reaction was quenched with saturated aqueous $\mathrm{NaHCO}_{3}(10 \mathrm{ml})$ at $0{ }^{\circ} \mathrm{C}$ and diluted with water $(20 \mathrm{ml})$ and $\mathrm{CH}_{2} \mathrm{Cl}_{2}(30$ $\mathrm{ml})$ and the aqueous layer was extracted with $\mathrm{CH}_{2} \mathrm{Cl}_{2}(3 \times 30 \mathrm{ml})$. The combined organic extracts were washed with water $(30 \mathrm{ml})$ and brine $(30 \mathrm{ml})$. The organic layer was dried over anhydrous sodium sulfate and filtered. The filtrate was concentrated under reduced pressure to give a crude material which was purified by silica gel column chromatography (30\% EtOAc/hexane) to afford mesyl compound ( $2.1 \mathrm{~g}$, quantitative) as yellow oil, which was used directly for the next reaction without any further characterization. To a stirred solution of mesyl compound in $t-\mathrm{BuOH}: \mathrm{H}_{2} \mathrm{O}$ $(1: 1,160 \mathrm{ml})$ were added AD-mix $\alpha(14.89 \mathrm{~g})$ and $\mathrm{MeSO}_{2} \mathrm{NH}_{2}(1.01 \mathrm{~g}, 10.66 \mathrm{mmol})$ at $0{ }^{\circ} \mathrm{C}$. After stirring at $0{ }^{\circ} \mathrm{C}$ for $24 \mathrm{~h}$ the reaction was quenched with saturated aqueous $\mathrm{Na}_{2} \mathrm{~S}_{2} \mathrm{O}_{5}(15.19$ g, $79.95 \mathrm{mmol}$ ) at $0{ }^{\circ} \mathrm{C}$ and the reaction mixture was warmed to room temperature and stirred for $30 \mathrm{~min}$. The reaction mixture was diluted with water $(50 \mathrm{ml})$ and extracted with ethyl acetate $(3 \mathrm{x}$ $50 \mathrm{ml})$. The combined organic extracts were washed with water $(50 \mathrm{ml})$ and brine $(50 \mathrm{ml})$. The organic layer was dried over anhydrous sodium sulfate and filtered. The filtrate was concentrated under reduced pressure to give a crude material, which was used in the next step without further purification.

The crude product obtained in the previous reaction was dissolved in anhydrous pyridine (16 ml) and stirred at $120{ }^{\circ} \mathrm{C}$ for $1 \mathrm{~h}$ under nitrogen atmosphere. Then the reaction mixture was cooled to room temperature and diluted with ethyl acetate $(90 \mathrm{ml})$. It was then washed with saturated aqueous $\mathrm{CuSO}_{4}(2 \times 25 \mathrm{ml})$, water $(30 \mathrm{ml})$ and brine $(30 \mathrm{ml})$. The organic layer was dried over anhydrous sodium sulfate and filtered. The filtrate was concentrated under reduced pressure to give a crude material, which was purified by silica gel column chromatography 
$\left(\mathrm{SiO}_{2}, 100-200 \mathrm{mesh}, 40 \% \mathrm{EtOAc} / \mathrm{hexane}\right)$ to afford 21 (1.31 g, $\left.3.87 \mathrm{mmol}, 72 \%\right)$ as a colorless oil. $R_{f}=0.4\left(\mathrm{SiO}_{2}, 50 \% \mathrm{EtOAc} /\right.$ hexane); $[\alpha]_{\mathrm{D}}{ }^{25}=+14.3\left(c 1.3 \mathrm{CHCl}_{3}\right)$; IR (Neat): $v_{\max } 3465$, 2966, 2926, 1744, 1611, 1513, 1461, 1373, 1298, 1247, 1207, 1087, 1032, 981, $823 \mathrm{~cm}^{-1} ;{ }^{1} \mathrm{H}$ NMR (500 MHz, $\left.\mathrm{CDCl}_{3}\right): \delta 7.25(\mathrm{~m}, 2 \mathrm{H}), 6.87(\mathrm{~m}, 2 \mathrm{H}), 4.64(\mathrm{~m}, 1 \mathrm{H}), 4.52(\mathrm{~d}, J=4.4 \mathrm{~Hz}, 1 \mathrm{H})$, $4.44(\mathrm{~s}, 2 \mathrm{H}), 4.36-4.22(\mathrm{~m}, 3 \mathrm{H}), 3.80$ (s, 3H), $3.58(\mathrm{dd}, J=9.2,5.0 \mathrm{~Hz}, 1 \mathrm{H}), 3.35$ (dd, $J=9.2,7.0$ Hz, 1H), 2.37 (brs, 1H), 2.06-1.98 (m, 2H), 1.84 (ddd, $J=13.2,10.2,5.2 \mathrm{~Hz}, 1 \mathrm{H}), 1.30(\mathrm{t}, J=$ $7.2 \mathrm{~Hz}, 3 \mathrm{H}), 0.93$ (d, $J=6.9 \mathrm{~Hz}, 3 \mathrm{H}) ;{ }^{13} \mathrm{C} \mathrm{NMR}\left(125 \mathrm{MHz}, \mathrm{CDCl}_{3}\right): \delta 170.49,159.01,130.67$, $129.10,113.68,81.91,80.95,73.53,72.73,72.46,61.21,55.23,38.29,38.09,14.23,12.89$. HRMS (ESI): [M + Na] ${ }^{+}$calcd. for $\mathrm{C}_{18} \mathrm{H}_{26} \mathrm{O}_{5} \mathrm{Na} 361.1622$, found 361.1629.

(2R,3S,5R)-Ethyl 3-methoxy-5-((S)-1-(4-methoxybenzyloxy)propan-2-yl)tetrahydrofuran-2carboxylate (13):
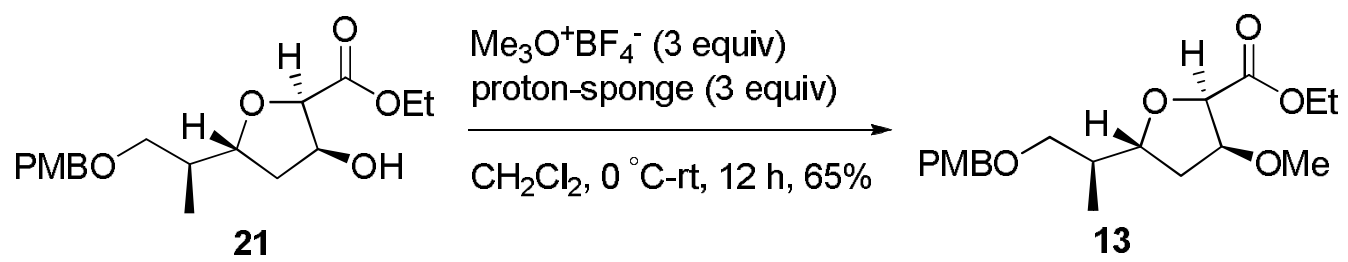

To a stirred solution of 21 (1.29 g, $3.81 \mathrm{mmol})$ in anhydrous $\mathrm{CH}_{2} \mathrm{Cl}_{2}(20 \mathrm{ml})$ were added proton-sponge $(2.45 \mathrm{~g}, 11.43 \mathrm{mmol})$ and trimethyloxoniumtetrafluoroborate $(1.69 \mathrm{~g}, 11.43$ mmol) at $0{ }^{\circ} \mathrm{C}$. The solution was warmed to room temperature and stirred for $12 \mathrm{~h}$. The reaction was quenched with saturated aqueous ammonium chloride $(20 \mathrm{ml})$ and diluted with water (20 $\mathrm{ml})$ and $\mathrm{CH}_{2} \mathrm{Cl}_{2}(20 \mathrm{ml})$. The aqueous layer was extracted with $\mathrm{CH}_{2} \mathrm{Cl}_{2}(3 \mathrm{x} 30 \mathrm{ml})$. The combined organic extracts were washed with water $(30 \mathrm{ml})$ and brine $(30 \mathrm{ml})$. The organic layer was dried over anhydrous sodium sulfate and filtered. The filtrate was concentrated under reduced pressure to give a crude material, which was purified by silica gel column chromatography ( $\mathrm{SiO}_{2}, 100-200 \mathrm{mesh}, 20 \% \mathrm{EtOAc} /$ hexane) to afford 13 (873 $\mathrm{mg}, 2.48 \mathrm{mmol}$, $65 \%)$ as a colorless oil. $R_{f}=0.5\left(\mathrm{SiO}_{2}, 30 \% \mathrm{EtOAc} / \mathrm{hexane}\right) ;[\alpha]_{\mathrm{D}}{ }^{25}=+22.6\left(c 0.89, \mathrm{CHCl}_{3}\right)$; IR (Neat): $v_{\max }$ 3746, 2927, 2849, 2310, 1756, 1612, 1513, 1460, 1369, 1296, 1247, 1198, 1092, 1033, $820 \mathrm{~cm}^{-1} ;{ }^{1} \mathrm{H}$ NMR (400 MHz, $\left.\mathrm{CDCl}_{3}\right): \delta 7.25(\mathrm{~m}, 2 \mathrm{H}), 6.87(\mathrm{~m}, 2 \mathrm{H}), 4.58(\mathrm{~d}, J=5.1 \mathrm{~Hz}$, $1 \mathrm{H}), 4.44$ (s, 2H), 4.31-4.14 (m, 4H), 3.80 (s, 3H), 3.60 (dd, $J=9.3,5.0 \mathrm{~Hz}, 1 \mathrm{H}), 3.34-3.31$ (m, 4H), $2.10(\mathrm{ddd}, J=13.0,5.7,2.0 \mathrm{~Hz}, 1 \mathrm{H}), 2.01(\mathrm{dtd}, J=13.9,7.0,5.0 \mathrm{~Hz}, 1 \mathrm{H}), 1.7-1.63(\mathrm{~m}, 1 \mathrm{H})$, $1.28(\mathrm{t}, J=7.1 \mathrm{~Hz}, 3 \mathrm{H}), 0.93(\mathrm{~d}, J=7.0 \mathrm{~Hz}, 3 \mathrm{H}) ;{ }^{13} \mathrm{C} \mathrm{NMR}\left(125 \mathrm{MHz}, \mathrm{CDCl}_{3}\right): \delta 170.01$, 
$159.00,130.77,129.08,113.66,82.58,81.19,80.87,72.68,72.53,60.62,57.77,55.23,38.26$, 34.18, 14.26, 13.04. HRMS (ESI): [M + Na $]^{+}$calcd. for $\mathrm{C}_{19} \mathrm{H}_{28} \mathrm{O}_{6} \mathrm{Na} 375.1778$, found 375.1790 .

\section{(Z)-Ethyl-3-((2S,3S,5R)-3-methoxy-5-((S)-1-(4-methoxybenzyloxy)propan-2-yl)tetrahy drofuran-2-yl)-2-methylacrylate (22):}

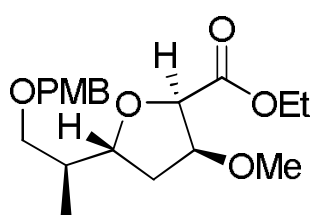

13
(1) DIBAL-H (1 equiv)

$\mathrm{CH}_{2} \mathrm{Cl}_{2},-78{ }^{\circ} \mathrm{C}, 30 \mathrm{~min}$

(2) 27 (2 equiv), KHMDS (1.8 equiv), $18-$-Crown-6 (3 equiv), THF, $-40^{\circ} \mathrm{C}$ to $-78{ }^{\circ} \mathrm{C}, 30 \mathrm{~min}, 75 \%$ over two steps

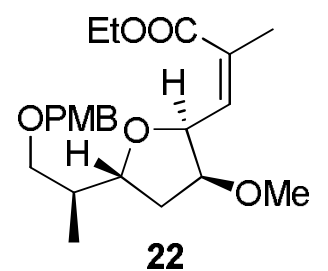

22

A stirred solution of $\mathbf{1 3}(850 \mathrm{mg}, 2.41 \mathrm{mmol})$ in anhydrous $\mathrm{CH}_{2} \mathrm{Cl}_{2}(7.2 \mathrm{ml})$ was treated with DIBAL-H (1.6 M toluene solution, $1.51 \mathrm{ml}, 2.41 \mathrm{mmol})$ drop wise over a period of $10 \mathrm{~min}$ at $-78{ }^{\circ} \mathrm{C}$ and stirred for $30 \mathrm{~min}$. After which time TLC (hexane:ethyl acetate $=1: 1$ ) indicated the complete consumption of $\mathbf{1 3}$. The reaction was quenched with methanol $(1.2 \mathrm{ml})$ and allowed to warm to $0{ }^{\circ} \mathrm{C}$. A saturated solution of sodium potassium tartrate $(4.8 \mathrm{ml})$ was added and the mixture was stirred for $2 \mathrm{~h}$ at room temperature. The layers were separated and the aqueous layer was extracted with $\mathrm{CH}_{2} \mathrm{Cl}_{2}(3 \times 20 \mathrm{ml})$ three times. The combined organic extracts were washed with water $(20 \mathrm{ml})$ and brine $(20 \mathrm{ml})$. The organic layer was dried over anhydrous sodium sulfate and filtered. The filtrate was concentrated under reduced pressure to give a crude material which was purified by silica gel column chromatography (50\% EtOAc/hexane) to afford an aldehyde as colorless oil, which was immediately used for the next step.

A solution of 18-Crown-6 (1.91 g, $7.23 \mathrm{mmol})$ and ethyl 2-[bis (2,2,2-trifluoroethyl) phosphono] propionate $27(1.67 \mathrm{~g}, 4.82 \mathrm{mmol})$ in anhydrous THF $(15 \mathrm{ml})$ was treated with KHMDS (0.5 M toluene solution, $8.68 \mathrm{ml}, 4.34 \mathrm{mmol})$ at $-40{ }^{\circ} \mathrm{C}$ and the resulting brown solution was stirred for $30 \mathrm{~min}$. Then the solution was further cooled down to $-78{ }^{\circ} \mathrm{C}$ and treated with a solution of aldehyde in anhydrous THF $(15 \mathrm{ml})$ and stirred for $30 \mathrm{~min}$. The reaction mixture was warmed to $0{ }^{\circ} \mathrm{C}$ and quenched with saturated aqueous ammonium chloride $(30 \mathrm{ml})$. The reaction mixture was extracted with ethyl acetate $(3 \times 30 \mathrm{ml})$. The combined organic extracts were washed with water $(30 \mathrm{ml})$ and brine $(30 \mathrm{ml})$. The organic layer was dried over anhydrous 
sodium sulfate and filtered. The filtrate was concentrated under reduced pressure to give a crude material, which was purified by silica gel column chromatography $\left(\mathrm{SiO}_{2}, 100-200\right.$ mesh, $14 \%$ EtOAc/hexane) to afford $22(710 \mathrm{mg}, 1.81 \mathrm{mmol}, 75 \%)$ as a colorless oil. $R_{\mathrm{f}}=0.6\left(\mathrm{SiO}_{2}, 40 \%\right.$ EtOAc/hexane); $[\alpha]_{\mathrm{D}}{ }^{25}=+47.3\left(c 0.83, \mathrm{CHCl}_{3}\right)$; IR (Neat): $v_{\max } 2970,2928,2311,1710,1652$, $1611,1513,1458,1369,1304,1243,1151,1102,1057,1034,945,822,760 \mathrm{~cm}^{-1} ;{ }^{1} \mathrm{H}$ NMR (400 $\left.\mathrm{MHz}, \mathrm{CDCl}_{3}\right): \delta 7.25(\mathrm{~m}, 2 \mathrm{H}), 6.86(\mathrm{~m}, 2 \mathrm{H}), 6.06(\mathrm{qd}, J=7.7,1.5 \mathrm{~Hz}, 1 \mathrm{H}), 5.13(\mathrm{dd}, J=7.5,4.0$ $\mathrm{Hz}, 1 \mathrm{H}), 4.42(\mathrm{~s}, 2 \mathrm{H}), 4.18(\mathrm{q}, J=7.1 \mathrm{~Hz}, 2 \mathrm{H}), 4.11-4.06(\mathrm{~m}, 2 \mathrm{H}), 3.80$ (s, 3H), 3.58 (dd, $J=9.2$, $5.0 \mathrm{~Hz}, 1 \mathrm{H}), 3.32$ (dd, $J=9.1,7.3 \mathrm{~Hz}, 1 \mathrm{H}), 3.28$ (s, 3H), 2.12 (dd, 13.1, $6.2 \mathrm{~Hz}, 1 \mathrm{H}), 1.95$ (s, $3 \mathrm{H}), 1.94-1.89(\mathrm{~m}, 1 \mathrm{H}), 1.75-1.65(\mathrm{~m}, 2 \mathrm{H}), 1.29(\mathrm{t}, J=7.2 \mathrm{~Hz}, 3 \mathrm{H}), 0.92(\mathrm{~d}, J=6.8 \mathrm{~Hz}, 3 \mathrm{H}) ;{ }^{13} \mathrm{C}$ NMR (100 MHz, $\left.\mathrm{CDCl}_{3}\right): \delta 167.40,158.97,140.59,130.85,129.05,128.75,113.65,83.76$, 79.60, 79.48, 72.76, 72.65, 60.36, 57.45, 55.22, 38.83, 35.40, 20.27, 14.22, 13.20. HRMS (ESI): $[\mathrm{M}+\mathrm{Na}]^{+}$calcd. for $\mathrm{C}_{22} \mathrm{H}_{32} \mathrm{O}_{6} \mathrm{Na}$ 415.2091, found 415.2096.

((2S,3S,5R)-3-Methoxy-5-((S)-1-(4-methoxybenzyloxy)propan-2-yl)tetrahydrofuran-2-yl)-2methylprop-2-en-1-ol (23):

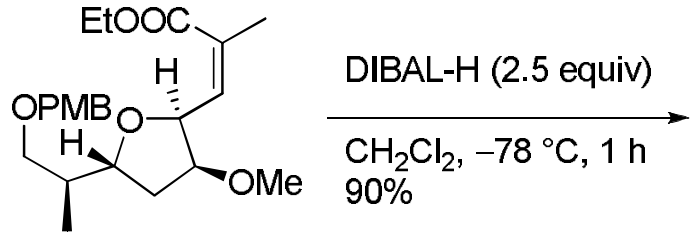

22

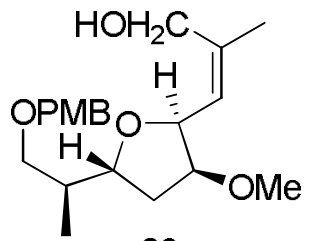

23

A stirred solution of compound $22(500 \mathrm{mg}, 1.27 \mathrm{mmol})$ in an hydrous $\mathrm{CH}_{2} \mathrm{Cl}_{2}(4 \mathrm{ml})$ was treated with DIBAL-H (1.6 M toluene solution, $1.98 \mathrm{ml}, 3.18 \mathrm{mmol})$ at $-78{ }^{\circ} \mathrm{C}$ and stirred for $30 \mathrm{~min}$. After which the reaction was quenched with methanol $(1 \mathrm{ml})$ and allowed to warm to $0{ }^{\circ} \mathrm{C}$. A saturated aqueous solution of sodium potassium tartrate $(4 \mathrm{ml})$ was added and the mixture was stirred at room temperature until the white suspension becomes clear solution. The layers were separated and the aqueous layer was extracted with $\mathrm{CH}_{2} \mathrm{Cl}_{2}$ (3 $\left.\mathrm{x} 25 \mathrm{ml}\right)$. The combined organic extracts were washed with water $(25 \mathrm{ml})$ and brine $(25 \mathrm{ml})$. The organic layer was dried over anhydrous sodium sulfate and filtered. The filtrate was concentrated under reduced pressure to give a crude material, which was purified by silica gel column chromatography (40\% EtOAc/hexane) to afford alcohol 23 (402 mg, $1.15 \mathrm{mmol}, 90 \%$ ) as a colorless oil. $R_{f}=0.25\left(\mathrm{SiO}_{2}, 60 \%\right.$ EtOAc/hexane $) ;[\alpha]_{\mathrm{D}}{ }^{25}=+9.6\left(c 0.38 \mathrm{CHCl}_{3}\right)$; IR $(\mathrm{Neat}): v_{\max }$ 
$3433,2924,1612,1512,1458,1365,1300,1246,1176,1097,1037,947,820 \mathrm{~cm}^{-1} ;{ }^{1} \mathrm{H}$ NMR $\left(500 \mathrm{MHz}, \mathrm{CDCl}_{3}\right): \delta 7.25(\mathrm{~m}, 2 \mathrm{H}), 6.87(\mathrm{~m}, 2 \mathrm{H}), 5.60(\mathrm{~d}, J=7.5 \mathrm{~Hz}, 1 \mathrm{H}), 4.67(\mathrm{dd}, J=7.3,3.9$ $\mathrm{Hz}, 1 \mathrm{H}), 4.42(\mathrm{~d}, J=1.2 \mathrm{~Hz}, 2 \mathrm{H}), 4.18(\mathrm{~d}, J=12.4 \mathrm{~Hz}, 1 \mathrm{H}), 4.10-4.00(\mathrm{~m}, 2 \mathrm{H}), 3.83-3.81(\mathrm{~m}$, $1 \mathrm{H}), 3.80(\mathrm{~s}, 3 \mathrm{H}), 3.55(\mathrm{dd}, J=9.2,4.9 \mathrm{~Hz}, 1 \mathrm{H}), 3.33$ (s, 3H), 3.31 (dd, $J=12.5,6.5 \mathrm{~Hz}, 1 \mathrm{H})$, 2.44 (brs, 1H), 2.13 (ddd, $J=8.4,6.4,2.0 \mathrm{~Hz}, 1 \mathrm{H}$ ), 1.96-1.89 (m, 1H), 1.86 (s, 3H), 1.76 (ddd, $J$ $=12.8,9.3,5.0 \mathrm{~Hz}, 1 \mathrm{H}), 0.92(\mathrm{~d}, J=6.9 \mathrm{~Hz}, 3 \mathrm{H}) ;{ }^{13} \mathrm{C} \mathrm{NMR}\left(100 \mathrm{MHz}, \mathrm{CDCl}_{3}\right): \delta 159.00$, $140.94,130.73,129.11,123.05,113.65,82.51,79.10,77.32,72.69,72.59,62.53,57.24,55.22$, 38.87, 34.67, 22.31, 13.30. HRMS (ESI): $[\mathrm{M}+\mathrm{Na}]^{+}$calcd. for $\mathrm{C}_{20} \mathrm{H}_{30} \mathrm{O}_{5} \mathrm{Na} 373.1986$, found 373.1992.

$(R, Z)-1-((2 S, 3 S, 5 R)-3-E t h o x y-5-((S)-1-(4-m e t h o x y b e n z y l o x y)$ propan-2-l)tetrahydrofuran-2yl)-2-methylhexa-1,5-dien-3-ol (24):

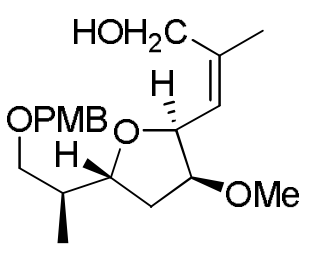

23
(1) $\mathrm{MnO}_{2}$ (12 equiv), $\mathrm{CHCl}_{3}$ $0^{\circ} \mathrm{C}-\mathrm{rt}, 16 \mathrm{~h}$

(2) (+)-Ipc $2 \mathrm{BOMe}(1.2$ equiv) allylmagnesium bromide (1.1 equiv) ether, $-78{ }^{\circ} \mathrm{C}, 2 \mathrm{~h}, 70 \%$, over two steps

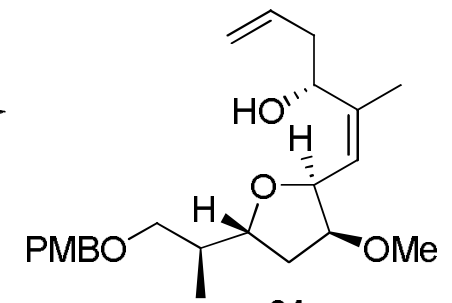

24

A solution of alcohol $23(370 \mathrm{mg}, 1.06 \mathrm{mmol})$ in anhydrous $\mathrm{CHCl}_{3}(6 \mathrm{ml})$ was treated with freshly activated $\mathrm{MnO}_{2}(1.11 \mathrm{~g}, 12.72 \mathrm{mmol})$ at $0{ }^{\circ} \mathrm{C}$ and the solution was stirred at room temperature for $16 \mathrm{~h}$ under dark. Then the reaction mixture was filtered through small Celite plug and washed with $\mathrm{CHCl}_{3}(30 \mathrm{ml})$. The filtrate was concentrated under reduced pressure to afford aldehyde, which was immediately used in next step without further purification.

A stirred solution of $(+)-\mathrm{Ipc}_{2} \mathrm{BOMe}(402 \mathrm{mg}, 1.27 \mathrm{mmol})$ in dry ether $(3.8 \mathrm{ml})$ was treated with a solution of allylmagnesium bromide $(1.0 \mathrm{M}$ ether solution, $1.17 \mathrm{ml}, 1.17 \mathrm{mmol})$ at $0{ }^{\circ} \mathrm{C}$. The resulting solution was allowed to warm to room temperature and stirred for additional $1 \mathrm{~h}$ to obtain a white suspension. The suspension was then cooled to $0{ }^{\circ} \mathrm{C}$ and allowed to settle for $30 \mathrm{~min}$. The supernatant was cannulated to a cooled solution of aldehyde in dry ether ( $2 \mathrm{ml}$ ) at $-78{ }^{\circ} \mathrm{C}$. The resulting mixture was stirred at $-78{ }^{\circ} \mathrm{C}$ for $2 \mathrm{~h}$ then allowed to warm to $0{ }^{\circ} \mathrm{C}$. The reaction was quenched with ethanol $(0.17 \mathrm{ml}), 3 \mathrm{~N}$ aqueous $\mathrm{NaOH}(0.45 \mathrm{ml})$ and $30 \% \mathrm{H}_{2} \mathrm{O}_{2}(0.89$ $\mathrm{ml})$. The reaction mixture was warmed to room temperature and stirred for $16 \mathrm{~h}$. The reaction 
mixture was diluted with water $(20 \mathrm{ml})$ and extracted with ether $(3 \times 20 \mathrm{ml})$. The combined organic extracts were washed with water $(20 \mathrm{ml})$ and brine $(20 \mathrm{ml})$. The organic layer was dried over anhydrous sodium sulfate and filtered. The filtrate was concentrated under reduced pressure to give a crude material, which was purified by silica gel column chromatography $\left(\mathrm{SiO}_{2}, 100-\right.$ $200 \mathrm{mesh}, 20 \% \mathrm{EtOAc} /$ hexane $)$ to afford alcohol $24(289 \mathrm{mg}, 0.83 \mathrm{mmol}, 70 \%)$ as a colorless oil. $R_{f}=0.35\left(\mathrm{SiO}_{2}, 40 \%\right.$ EtOAc/hexane); $[\alpha]_{\mathrm{D}}^{25}=+7.7$ (c 1.18, $\left.\mathrm{CHCl}_{3}\right)$; IR (Neat): $v_{\max } 3747,3464$, 2925, 2855, 2311, 1701, 1610, 1513, 1458, 1248, 1173, 1094, 1035, $823 \mathrm{~cm}^{-1} ;{ }^{1} \mathrm{H}$ NMR (400 $\left.\mathrm{MHz}, \mathrm{CDCl}_{3}\right): \delta 7.24(\mathrm{~m}, 2 \mathrm{H}), 6.86(\mathrm{~m}, 2 \mathrm{H}), 5.81(\mathrm{ddt}, J=17.2,10.1,7.4 \mathrm{~Hz}, 1 \mathrm{H}), 5.57(\mathrm{dd}, J=$ 8.0, 1.0 Hz, 1H), 5.18-5.08 (m, 2H), $4.70(\mathrm{dd}, J=8.0,4.0 \mathrm{~Hz}, 1 \mathrm{H}), 4.50(\mathrm{t}, J=6.8 \mathrm{~Hz}, 1 \mathrm{H}), 4.42$ (s, 2H), $4.03(\mathrm{td}, J=9.0,7.0 \mathrm{~Hz}, 1 \mathrm{H}), 3.84-3.81(\mathrm{~m}, 1 \mathrm{H}), 3.80(\mathrm{~s}, 3 \mathrm{H}), 3.58(\mathrm{dd}, J=9.1,4.8 \mathrm{~Hz}$, 1H), 3.34 (s, 3H), 3.31 (dd, $J=10.1,3.0 \mathrm{~Hz}, 1 \mathrm{H}), 2.39-2.33$ (m, 2H), 2.12 (ddd, $J=8.8,6.6,2.2$ $\mathrm{Hz}, 1 \mathrm{H}), 1.95-1.87(\mathrm{~m}, 1 \mathrm{H}), 1.79(\mathrm{~d}, J=1.0 \mathrm{~Hz}, 3 \mathrm{H}), 1.74(\mathrm{dd}, J=9.1,4.8 \mathrm{~Hz}, 1 \mathrm{H}), 0.92(\mathrm{~d}, J=$ $6.8 \mathrm{~Hz}, 3 \mathrm{H}) ;{ }^{13} \mathrm{C}$ NMR $\left(125 \mathrm{MHz}, \mathrm{CDCl}_{3}\right): \delta 159.00,142.21,134.84,130.78,129.07,123.06$, 117.67, 113.66, 82.51, 78.80, 76.54, 72.70, 72.68, 69.95, 57.23, 55.23, 39.80, 38.98, 34.66, 18.65, 13.37. HRMS (ESI): $[\mathrm{M}+\mathrm{Na}]^{+}$calcd. for $\mathrm{C}_{23} \mathrm{H}_{34} \mathrm{O}_{5} \mathrm{Na} 413.2299$, found 413.2312.

\section{tert-Butyl $((R, Z)-1-((2 S, 3 S, 5 R)-3-$ methoxy-5-((S)-1-(4-methoxybenzyloxy)propan-2-yl)}

tetrahydrofuran-2-yl)-2-methylhexa-1,5-dien-3-yloxy)dimethylsilane (25):

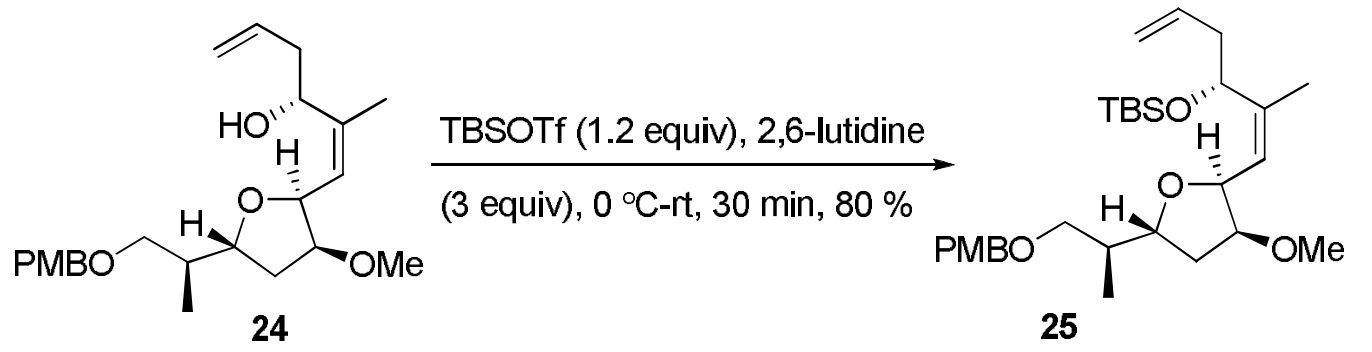

A stirred solution of alcohol $24(260 \mathrm{mg}, 0.67 \mathrm{mmol})$ in dry $\mathrm{CH}_{2} \mathrm{Cl}_{2}(2 \mathrm{ml})$ was treated with 2,6-lutidine $(0.23 \mathrm{ml}, 2.01 \mathrm{mmol})$ followed by TBSOTf $(0.19 \mathrm{ml}, 0.80 \mathrm{mmol})$ at $0{ }^{\circ} \mathrm{C}$. The solution was warmed to room temperature and stirred for $30 \mathrm{~min}$. After which the reaction was quenched with saturated aqueous $\mathrm{NaHCO}_{3}(5 \mathrm{ml})$ at $0{ }^{\circ} \mathrm{C}$ and diluted with water $(20 \mathrm{ml})$. The reaction mixture was extracted with $\mathrm{CH}_{2} \mathrm{Cl}_{2}(3 \times 20 \mathrm{ml})$. The combined organic extracts were washed with water $(20 \mathrm{ml})$ and brine $(20 \mathrm{ml})$. The organic layer was dried over anhydrous sodium sulfate and filtered. The filtrate was concentrated under reduced pressure to give a crude 
material which was purified by silica gel column chromatography $\left(\mathrm{SiO}_{2}, 100-200\right.$ mesh, 5\% EtOAc/hexane) to afford 25 (269 mg, $0.53 \mathrm{mmol}, 80 \%)$ as a colorless oil. $R_{f}=0.5\left(\mathrm{SiO}_{2}, 15 \%\right.$ EtOAc/hexane); $[\alpha]_{\mathrm{D}}^{25}=-4.5$ (c 1.4, $\left.\mathrm{CHCl}_{3}\right)$; IR (Neat): $v_{\max } 3072,2930,2894,2856,1613$, 1513, 1463, 1364, 1299, 1248, 1176, 1070, 1006, 943, 914, 833, 776, $670 \mathrm{~cm}^{-1}$; ${ }^{1} \mathrm{H}$ NMR (400 $\left.\mathrm{MHz}, \mathrm{CDCl}_{3}\right): \delta 7.24(\mathrm{~m}, 2 \mathrm{H}), 6.86(\mathrm{~m}, 2 \mathrm{H}), 5.81(\mathrm{ddt}, J=17.2,10.1,7.4 \mathrm{~Hz}, 1 \mathrm{H}), 5.47(\mathrm{qd}, J=$ 8.4, 0.6 Hz, 1H), 5.08-4.97 (m, 2H), 4.56 (td, $J=9.3,4.2 \mathrm{~Hz}, 2 \mathrm{H}), 4.42$ (s, 2H), 4.03-3.96 (dd, $J$ $=14.0,7.6 \mathrm{~Hz}, 1 \mathrm{H}), 3.80(\mathrm{~s}, 3 \mathrm{H}), 3.76(\mathrm{td}, J=5.0,1.5 \mathrm{~Hz}, 1 \mathrm{H}), 3.63(\mathrm{dd}, J=9.0,4.6 \mathrm{~Hz}, 1 \mathrm{H})$, 3.32 (s, 3H), 3.31-3.26 (m, 1H), 2.39-2.20 (m, 2H), 2.15 (ddd, $J=13.2,6.2,1.2 \mathrm{~Hz}, 1 \mathrm{H}), 1.95-$ $1.87(\mathrm{~m}, 1 \mathrm{H}), 1.75(\mathrm{~d}, J=1.2 \mathrm{~Hz}, 3 \mathrm{H}), 1.70(\mathrm{dd}, J=9.5,4.8 \mathrm{~Hz}, 1 \mathrm{H}), 0.92(\mathrm{~d}, J=6.6 \mathrm{~Hz}, 3 \mathrm{H})$, 0.88 (s, 9H), 0.03 (s, 3H); 0.01 (s, 3H); $\left.{ }^{13} \mathrm{C} \mathrm{NMR} \mathrm{(100} \mathrm{MHz,} \mathrm{CDCl}_{3}\right): \delta 159.00,143.74,135.72$, 130.86, 129.04, 120.52, 116.45, 113.67, 82.77, 78.76, 76.53, 72.91, 72.71, 71.24, 57.24, 55.24, $41.41,39.13,35.19,25.77,18.25,18.19,13.32,-4.76,-4.79$. HRMS (ESI): $[\mathrm{M}+\mathrm{Na}]^{+} \mathrm{calcd}$. for $\mathrm{C}_{29} \mathrm{H}_{48} \mathrm{O}_{5} \mathrm{NaSi}$ 527.3163, found 527.3177.

\section{(S)-2-((2R,4S,5S)-5-((R,Z)-3-(tert-Butyldimethylsilyloxy)-2-methylhexa-1,5-dienyl)-4-} methoxytetrahydrofuran-2-yl)propan-1-ol (26):

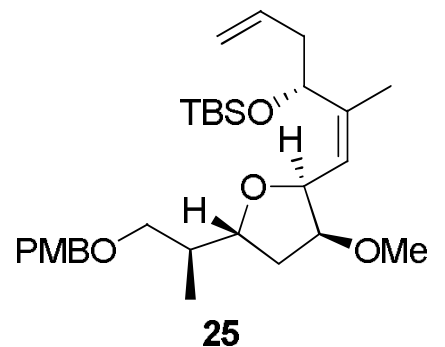

25

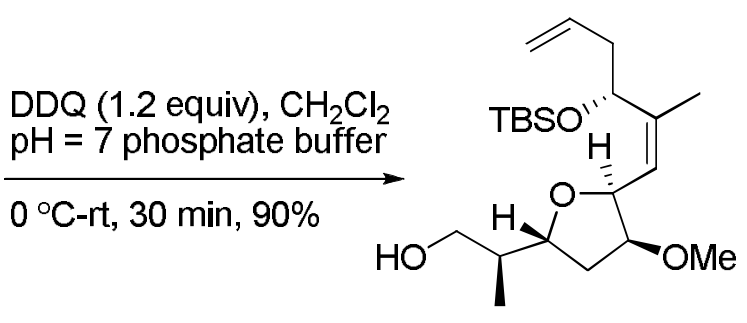

26

A stirred solution of $25(250 \mathrm{mg}, 0.5 \mathrm{mmol})$ in a mixture of solvents $\mathrm{CH}_{2} \mathrm{Cl}_{2}$ and $\mathrm{pH}=7$ phosphate buffer ( $3 \mathrm{ml}, 20: 1)$ was treated with DDQ (136 mg, $0.6 \mathrm{mmol})$ at $0{ }^{\circ} \mathrm{C}$. The solution was warmed to room temperature and stirred for $30 \mathrm{~min}$. After which the reaction was quenched with saturated aqueous $\mathrm{NaHCO}_{3}(5 \mathrm{ml})$ at $0{ }^{\circ} \mathrm{C}$ and diluted with water $(20 \mathrm{ml}), \mathrm{CH}_{2} \mathrm{Cl}_{2}(20 \mathrm{ml})$. The layers were separated and the aqueous layer was extracted with $\mathrm{CH}_{2} \mathrm{Cl}_{2}$ (3 x $\left.20 \mathrm{ml}\right)$ three times. The combined organic extracts were washed with water $(20 \mathrm{ml})$ and brine $(20 \mathrm{ml})$. The organic layer was dried over anhydrous sodium sulfate and filtered. The filtrate was concentrated under reduced pressure to give a crude material which was purified by silica gel column chromatography (17\% EtOAc/hexane) to afford alcohol 26 (172 $\mathrm{mg}, 0.45 \mathrm{mmol}, 90 \%)$ as a 
colorless oil. $R_{f}=0.4\left(\mathrm{SiO}_{2}, 30 \% \mathrm{EtOAc} /\right.$ hexane $) ;[\alpha]_{\mathrm{D}}{ }^{25}=+12.2\left(c 0.5, \mathrm{CHCl}_{3}\right) ; \mathrm{IR}(\mathrm{Neat}): v_{\max }$ 3744, 3470, 2926, 2856, 1723, 1646, 1463, 1369, 1252, 1076, 1040, 1005, 941, 915, 836, 776, $668 \mathrm{~cm}^{-1} ;{ }^{1} \mathrm{H} \mathrm{NMR}\left(400 \mathrm{MHz}, \mathrm{CDCl}_{3}\right): \delta 5.74(\mathrm{ddt}, J=17.2,10.2,7.2 \mathrm{~Hz}, 1 \mathrm{H}), 5.46(\mathrm{~d}, J=9.0$ $\mathrm{Hz}, 1 \mathrm{H}), 5.09-5.00(\mathrm{~m}, 2 \mathrm{H}), 4.69(\mathrm{dd}, 13.7,9.0 \mathrm{~Hz}, 1 \mathrm{H}), 4.52(\mathrm{t}, J=6.8 \mathrm{~Hz}, 1 \mathrm{H}), 3.97(\mathrm{dt}, J=$ 9.4, $5.9 \mathrm{~Hz}, 1 \mathrm{H}), 3.75(\mathrm{td}, J=4.6,1.5 \mathrm{~Hz}, 1 \mathrm{H}), 3.61(\mathrm{dd}, J=11.0,8.3 \mathrm{~Hz}, 1 \mathrm{H}), 3.56(\mathrm{dd}, J=$ 11.0, $3.7 \mathrm{~Hz}, 1 \mathrm{H}), 3.34$ (s, 3H), 2.38-2.16 (m, 3H), 1.75 (d, $J=1.2 \mathrm{~Hz}, 3 \mathrm{H}), 1.73-1.65$ (m, 2H), $0.87(\mathrm{~s}, 9 \mathrm{H}), 0.79(\mathrm{~d}, J=6.8 \mathrm{~Hz}, 3 \mathrm{H}), 0.03(\mathrm{~s}, 3 \mathrm{H}), 0.01(\mathrm{~s}, 3 \mathrm{H}) ;{ }^{13} \mathrm{C} \mathrm{NMR}\left(100 \mathrm{MHz}, \mathrm{CDCl}_{3}\right): \delta$ 143.54, 134.89, 120.38, 117.00, 83.41, 82.01, 76.83, 70.94, 68.48, 57.50, 41.28, 41.19, 37.50, $25.74,18.27,18.17,13.18,-4.75,-4.79$. HRMS (ESI): $[\mathrm{M}+\mathrm{Na}]^{+}$calcd. for $\mathrm{C}_{21} \mathrm{H}_{40} \mathrm{O}_{4} \mathrm{NaSi}$ 407.2588, found 407.2596 .

\section{tert-Butyl-((2S,3R)-3-methoxypent-4-yn-2-yloxy)-dimethylsilane (11):}

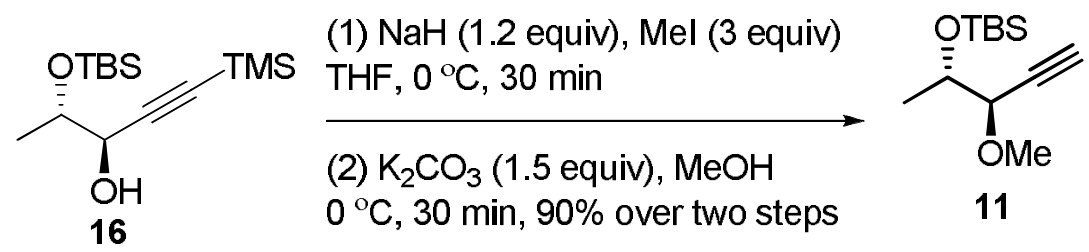

A stirred solution of $16(580 \mathrm{mg}, 2.02 \mathrm{mmol})$ in anhydrous THF (6 ml) was treated with $\mathrm{NaH}(97 \mathrm{mg}, 2.42 \mathrm{mmol})$ followed by freshly distilled $\mathrm{MeI}(0.38 \mathrm{ml}, 6.06 \mathrm{mmol})$ at $0{ }^{\circ} \mathrm{C}$ and stirred for $30 \mathrm{~min}$. After which the reaction was quenched with saturated aqueous ammonium chloride $(10 \mathrm{ml})$ and extracted with ether $(3 \mathrm{x} 20 \mathrm{ml})$. The combined organic extracts were washed with water $(20 \mathrm{ml})$ and brine $(20 \mathrm{ml})$. The organic layer was dried over anhydrous sodium sulfate and filtered. The filtrate was concentrated under reduced pressure to give a crude material, which was used in the next step without further purification.

A solution of above crude compound in anhydrous $\mathrm{MeOH}(3 \mathrm{ml})$ was treated with anhydrous $\mathrm{K}_{2} \mathrm{CO}_{3}(418 \mathrm{mg}, 3.03 \mathrm{mmol})$ at $0{ }^{\circ} \mathrm{C}$. The solution was warmed to room temperature and stirred for $30 \mathrm{~min}$. The reaction mixture was filtered through small Celite plug and washed with ether. The filtrate and washings were concentrated under reduced pressure to give brown residue. The brown residue was diluted with ether $(20 \mathrm{ml})$ and saturated aqueous ammonium chloride $(20 \mathrm{ml})$ and stirred for $10 \mathrm{~min}$. The layers were separated and the aqueous layer was extracted with ether $(3 \times 20 \mathrm{ml})$. The combined organic extracts were washed with water $(20 \mathrm{ml})$ 
and brine $(20 \mathrm{ml})$. The organic layer was dried over anhydrous sodium sulfate and filtered. The filtrate was concentrated under reduced pressure to give a crude material which was purified by silica gel column chromatography $\left(\mathrm{SiO}_{2}, 100-200\right.$ mesh, 2\% EtOAc/hexane) to afford alkyne 11 (416 mg, $1.83 \mathrm{mmol}, 90 \%)$ as a pale brown oil. $R_{f}=0.7\left(\mathrm{SiO}_{2}, 5 \%\right.$ EtOAc/hexane); $[\alpha]_{\mathrm{D}}{ }^{25}=$ -20.1 (c $0.8 \mathrm{CHCl}_{3}$ ); IR (Neat): $v_{\max } 3309,2928,2856,1736,1716,1464,1371,1253,1194$, 1117, 1029, 1003, 945, 834, 777, 661, $631 \mathrm{~cm}^{-1} ;{ }^{1} \mathrm{H}$ NMR (400 MHz, $\left.\mathrm{CDCl}_{3}\right): \delta 3.89(\mathrm{~m}, 1 \mathrm{H})$, $3.76(\mathrm{dd}, J=5.3,2.1 \mathrm{~Hz}, 1 \mathrm{H}), 3.44(\mathrm{~s}, 3 \mathrm{H}), 2.41(\mathrm{~d}, J=2.1 \mathrm{~Hz}, 1 \mathrm{H}), 1.23(\mathrm{~d}, J=6.1 \mathrm{~Hz}, 3 \mathrm{H})$, 0.89 (s, 9H), 0.09 (s, 3H); 0.08 (s, 3H); ${ }^{13} \mathrm{C} \mathrm{NMR}\left(100 \mathrm{MHz}, \mathrm{CDCl}_{3}\right): \delta 81.25,76.58,74.50$, 70.60, 57.16, 25.83, 19.51, 18.15, -4.56, -4.66. HRMS (EI-MS):[M] ${ }^{+}$calcd. for $\mathrm{C}_{12} \mathrm{H}_{24} \mathrm{O}_{2} \mathrm{Si}$ 228.1545 , found 228.1545 .

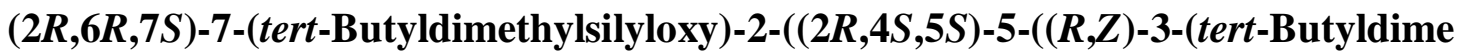

\section{thylsilyloxy)-2-methylhexa-1,5-dienyl)-4-methoxytetrahydrofuran-2-yl)-6-methoxyoct}

\section{-4-yn-3-one (29):}

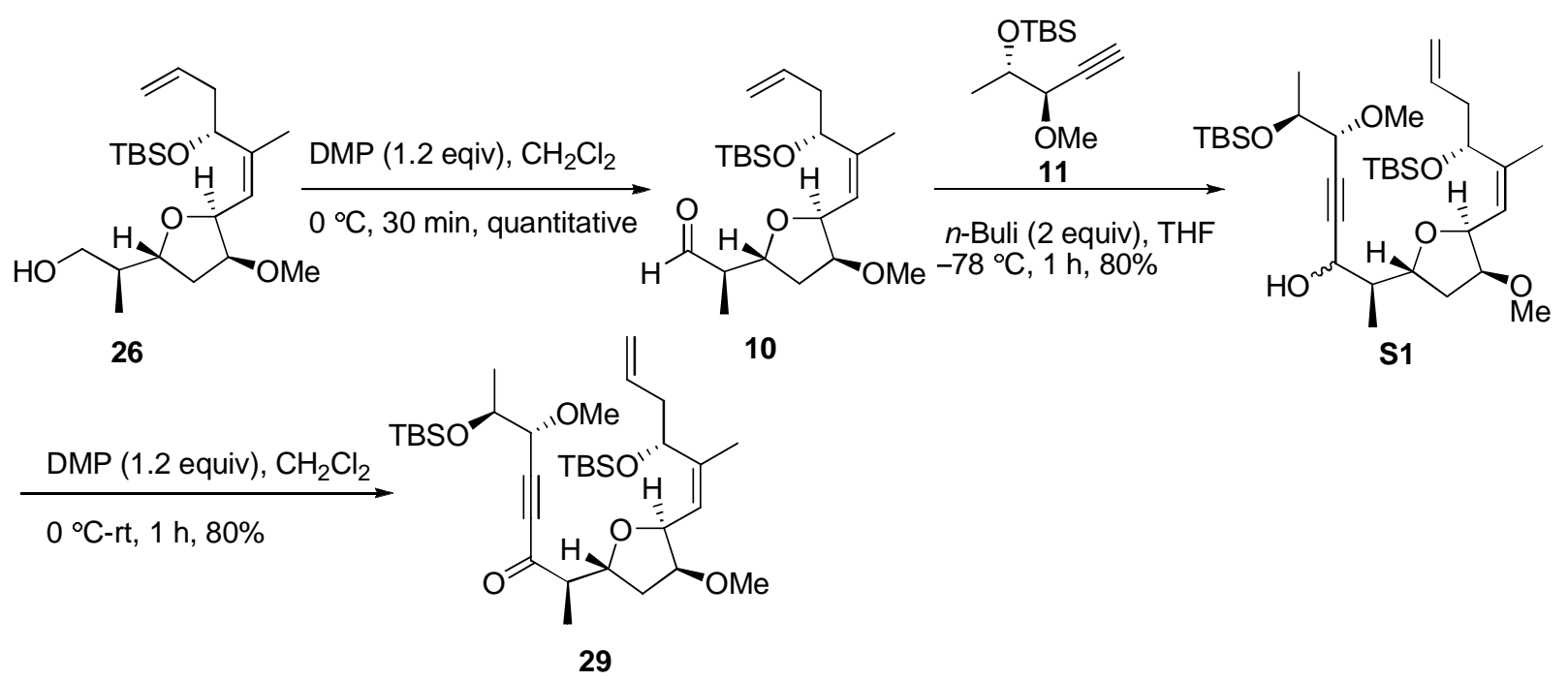

A stirred solution of alcohol 26 (125 mg, $0.33 \mathrm{mmol})$ in $\mathrm{CH}_{2} \mathrm{Cl}_{2}(2 \mathrm{ml})$ was treated with DMP (168 $\mathrm{mg}, 0.41 \mathrm{mmol})$ at $0{ }^{\circ} \mathrm{C}$ and stirred at room temperature for $30 \mathrm{~min}$. The reaction was quenched with (1:1) mixture of saturated aqueous hypo and saturated aqueous $\mathrm{NaHCO}_{3}(5 \mathrm{ml})$ at $0{ }^{\circ} \mathrm{C}$ and diluted with water $(5 \mathrm{ml}), \mathrm{CH}_{2} \mathrm{Cl}_{2}(10 \mathrm{ml})$. The layers were separated and the aqueous layer was extracted with $\mathrm{CH}_{2} \mathrm{Cl}_{2}(3 \times 20 \mathrm{ml})$. The organic extracts were washed with water $(20$ $\mathrm{ml})$ and brine $(20 \mathrm{ml})$. The organic layer was dried over anhydrous sodium sulfate and filtered. 
The filtrate was concentrated under reduced pressure to give a crude material which was purified by silica gel column chromatography $\left(\mathrm{SiO}_{2}, 100-200\right.$ mesh, 50\% EtOAc/hexane) to afford aldehyde 10 (120 mg, $0.31 \mathrm{mmol}$, quantitative) as a colorless oil. $R_{f}=0.5\left(\mathrm{SiO}_{2}, 20 \%\right.$ EtOAc/hexane) which was used immediately in the next step.

A stirred solution of alkyne $11(151 \mathrm{mg}, 0.66 \mathrm{mmol})$ in dry THF $(1.5 \mathrm{ml})$ was treated with $n$-Buli $(1.6 \mathrm{M}$ hexane solution, $0.39 \mathrm{ml}, 0.62 \mathrm{mmol})$ at $-78{ }^{\circ} \mathrm{C}$ and the solution was warmed slowly (over a period of $45 \mathrm{~min}$.) to $-10{ }^{\circ} \mathrm{C}$. The reaction mixture was again cooled to $-78{ }^{\circ} \mathrm{C}$ and aldehyde 10 (120 mg, $0.31 \mathrm{mmol})$ in dry THF (3 ml) was cannulated to the reaction mixture and stirred for $1 \mathrm{~h}$. The solution was warmed to $0{ }^{\circ} \mathrm{C}$ and quenched with saturated aqueous $\mathrm{NH}_{4} \mathrm{Cl}$ $(5 \mathrm{ml})$ and diluted with water $(5 \mathrm{ml})$ and ethyl acetate $(5 \mathrm{ml})$. The layers were separated and the aqueous layer was extracted with ethyl acetate $(3 \times 20 \mathrm{ml})$. The combined organic extracts were washed with water $(20 \mathrm{ml})$ and brine $(20 \mathrm{ml})$. The organic layer was dried over anhydrous sodium sulfate and filtered. The filtrate was concentrated under reduced pressure to give a crude material which was purified by silica gel column chromatography ( $8 \%$ EtOAc/hexane) to afford diastereomeric mixture of alcohols $\mathbf{S 1}$ (153 mg, 0.25mmol, 80\%) as a brown oil.

Diastereomeric mixture of alcohols S1 (120 mg, $0.20 \mathrm{mmol})$ obtained above were dissolved in anhydrous $\mathrm{CH}_{2} \mathrm{Cl}_{2}(4 \mathrm{ml})$ and treated with DMP $(102 \mathrm{mg}, 0.24 \mathrm{mmol})$ at $0{ }^{\circ} \mathrm{C}$. The reaction mixture was warmed to room temperature and stirred for $1 \mathrm{~h}$. The reaction was quenched with (1:1) mixture of saturated aqueous hypo and saturated aqueous $\mathrm{NaHCO}_{3}(5 \mathrm{ml})$ at $0{ }^{\circ} \mathrm{C}$ and stirred at room temperature for $30 \mathrm{~min}$. It was then diluted with water $(5 \mathrm{ml}), \mathrm{CH}_{2} \mathrm{Cl}_{2}(5$ $\mathrm{ml})$ and the layers were separated. The aqueous layer was extracted with $\mathrm{CH}_{2} \mathrm{Cl}_{2}(3 \mathrm{x} 20 \mathrm{ml})$. The combined organic extracts were washed with water $(20 \mathrm{ml})$ and brine $(20 \mathrm{ml})$. The organic layer was dried over anhydrous sodium sulfate and filtered. The filtrate was concentrated under reduced pressure to give a crude material which was purified by silica gel column chromatography (7\% EtOAc/hexane) to afford alkynone 29 (95 $\mathrm{mg}, 0.16 \mathrm{mmol}, 80 \%)$ as a colorless oil. $R_{f}=0.6\left(\mathrm{SiO}_{2}, 20 \%\right.$ EtOAc/hexane); $[\alpha]_{\mathrm{D}}{ }^{25}=-20.2\left(c 0.7, \mathrm{CHCl}_{3}\right)$; IR (Neat): $v_{\max }$ 2930, 2857, 2210, 1677, 1463, 1369, 1253, 1114, 1076, 1002, 940, 835, 777, $669 \mathrm{~cm}^{-1} ;{ }^{1} \mathrm{H}$ NMR $\left(400 \mathrm{MHz}, \mathrm{CDCl}_{3}\right): \delta 5.79(\mathrm{ddt}, J=17.4,10.1,7.2 \mathrm{~Hz}, 1 \mathrm{H}), 5.44(\mathrm{~d}, J=7.9 \mathrm{~Hz}, 1 \mathrm{H}), 5.08-4.98$ $(\mathrm{m}, 2 \mathrm{H}), 4.60(\mathrm{dd}, J=8.4,3.7 \mathrm{~Hz}, 1 \mathrm{H}), 4.51(\mathrm{dd}, J=8.4,5.5 \mathrm{~Hz}, 1 \mathrm{H}), 3.99-3.90(\mathrm{~m}, 2 \mathrm{H}), 3.80$ $(\mathrm{dt}, J=5.2,1.5 \mathrm{~Hz}, 1 \mathrm{H}), 3.43(\mathrm{~s}, 3 \mathrm{H}), 3.32(\mathrm{~s}, 3 \mathrm{H}), 2.81$ (quin, $J=7.1 \mathrm{~Hz}, 1 \mathrm{H}), 2.37-2.14(\mathrm{~m}$, 
4H), $1.74(\mathrm{~d}, J=1.2 \mathrm{~Hz}, 3 \mathrm{H}), 1.71(\mathrm{dd}, J=9.0,5.0 \mathrm{~Hz}, 1 \mathrm{H}), 1.22(\mathrm{~d}, J=6.0 \mathrm{~Hz}, 3 \mathrm{H}), 1.16(\mathrm{~d}, J$ $=7.1 \mathrm{~Hz}, 3 \mathrm{H}), 0.88(\mathrm{~s}, 9 \mathrm{H}), 0.87(\mathrm{~s}, 9 \mathrm{H}), 0.08(\mathrm{~s}, 3 \mathrm{H}), 0.07(\mathrm{~s}, 3 \mathrm{H}), 0.03(\mathrm{~s}, 3 \mathrm{H}), 0.01(\mathrm{~s}, 3 \mathrm{H})$; ${ }^{13} \mathrm{C}$ NMR (100 MHz, $\left.\mathrm{CDCl}_{3}\right): \delta$ 188.64, 144.21, 135.57, 119.91, 116.56, 90.37, 84.41, 82.39, 77.20, 76.85, 71.18, 70.23, 57.50, 57.32, 53.69, 41.41, 34.31, 25.77, 19.84, 18.22, 18.07, 11.50, 4.67, -4.74, -4.81. HRMS (ESI): $\left[\mathrm{M}+\mathrm{NH}_{4}\right]^{+}$calcd. for $\mathrm{C}_{33} \mathrm{H}_{64} \mathrm{O}_{6} \mathrm{NSi}_{2} 626.4267$, found 626.4287.

\section{$(2 S, 3 S, 6 R, 7 S)-7-($ tert-Butyldimethylsilyloxy)-2-((2R,4S,5S)-5-((R,Z)-3-(tert-}

butyldimethylsilyloxy)-2-methylhexa-1,5-dienyl)-4-methoxytetrahydrofuran-2-yl)-6methoxyoct-4-yn-3-ol (30):

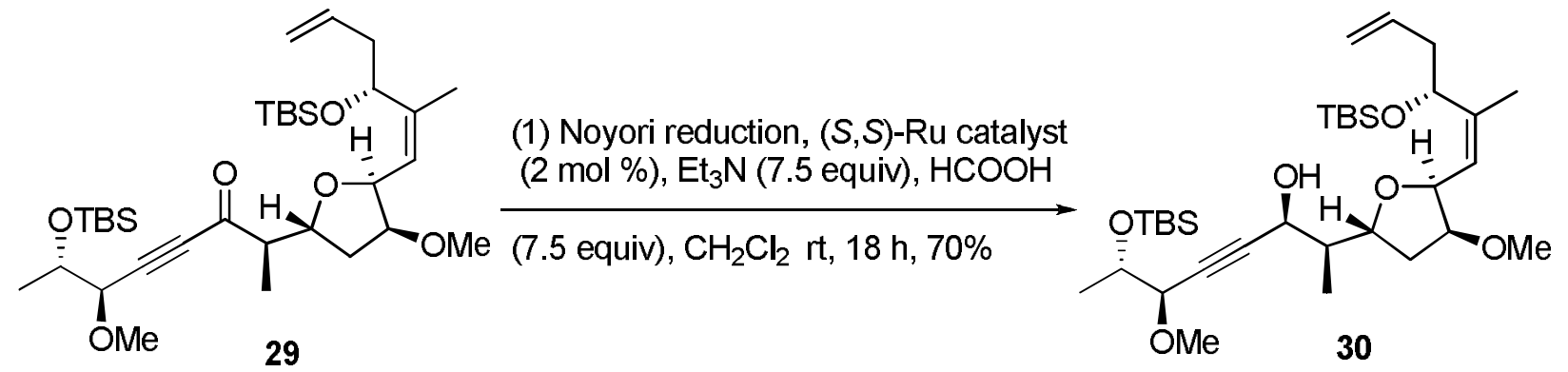

To a solution of alkynone $29(80 \mathrm{mg}, 0.13 \mathrm{mmol})$ in anhydrous $\mathrm{CH}_{2} \mathrm{Cl}_{2}(4 \mathrm{ml}), \mathrm{Et}_{3} \mathrm{~N}(0.14$ $\mathrm{ml}, 0.98 \mathrm{mmol})$ and $\mathrm{HCOOH}(37 \mu 1,0.98 \mathrm{mmol})$ were added at $0{ }^{\circ} \mathrm{C}$ under argon and stirred for 5 min. To the above solution was added in situ generated $(S, S)$-Ru catalyst $\left(0.01 \mathrm{M} \mathrm{CH}_{2} \mathrm{Cl}_{2}\right.$ solution, $0.26 \mathrm{ml}, 0.0026 \mathrm{mmol}, 2 \mathrm{~mol} \%$ ) at $0{ }^{\circ} \mathrm{C}$. The solution was warmed to room temperature and stirred for $18 \mathrm{~h}$. The reaction was quenched with saturated aqueous $\mathrm{NH}_{4} \mathrm{Cl}(5 \mathrm{ml})$ and diluted with water $(5 \mathrm{ml})$. The layers were separated and the aqueous layer was extracted with $\mathrm{CH}_{2} \mathrm{Cl}_{2}(3$ x $15 \mathrm{ml})$. The combined organic extracts were washed with water $(15 \mathrm{ml})$ and brine $(15 \mathrm{ml})$. The organic layer was dried over anhydrous sodium sulfate and filtered. The filtrate was concentrated under reduced pressure to give a crude material which was purified by silica gel column chromatography ( $\mathrm{SiO}_{2}, 100-200$ mesh, 8\% EtOAc/hexane) to afford alcohol 30 (56 mg, 0.092 mmol, 70\%) as a brown oil. $R_{f}=0.45\left(\mathrm{SiO}_{2}, 20 \% \mathrm{EtOAc} / \mathrm{hexane}\right) ;[\alpha]_{\mathrm{D}}{ }^{25}=-30.2\left(c 0.5, \mathrm{CHCl}_{3}\right)$; IR (Neat): $v_{\max } 3434,2930,2857,1720,1642,1371,1253,1198,1099,1004,836,779 \mathrm{~cm}^{-1} ;{ }^{1} \mathrm{H}$ NMR (700 MHz, $\left.\mathrm{CDCl}_{3}\right): \delta 5.73(\mathrm{ddt}, J=17.2,10.4,7.3 \mathrm{~Hz}, 1 \mathrm{H}), 5.44(\mathrm{dd}, J=9.2,1.5 \mathrm{~Hz}, 1 \mathrm{H})$, $5.07(\mathrm{dd}, J=10.4,2.0 \mathrm{~Hz}, 1 \mathrm{H}), 5.04(\mathrm{dd}, J=17.2,2.0 \mathrm{~Hz}, 1 \mathrm{H}), 4.71(\mathrm{dd}, J=9.2,4.0 \mathrm{~Hz}, 1 \mathrm{H})$, $4.51(\mathrm{dd}, J=7.3,6.5 \mathrm{~Hz}, 1 \mathrm{H}), 4.45(\mathrm{~m}, 1 \mathrm{H}), 4.34(\mathrm{td}, J=9.5,5.8, \mathrm{~Hz}, 1 \mathrm{H}), 3.93(\mathrm{qd}, J=6.4,4.0$ 
$\mathrm{Hz}, 1 \mathrm{H}), 3.87(\mathrm{dd}, J=4.0,1.5 \mathrm{~Hz}, 1 \mathrm{H}), 3.76(\mathrm{t}, J=4.0 \mathrm{~Hz}, 1 \mathrm{H}), 3.41(\mathrm{~s}, 3 \mathrm{H}), 3.31(\mathrm{~s}, 3 \mathrm{H}), 2.28$ (ddd, $J=13.2,6.5,1.5 \mathrm{~Hz}, 1 \mathrm{H}), 2.32(\mathrm{~m}, 13.5,7.5 \mathrm{~Hz}, 1 \mathrm{H}), 2.22(\mathrm{~m}, J=13.5,7.3,6.5 \mathrm{~Hz}, 1 \mathrm{H})$, 1.87 (ddd, $J=9.8,6.7,2.9 \mathrm{~Hz}, 2 \mathrm{H}), 1.75(\mathrm{~d}, J=1.5 \mathrm{~Hz}, 3 \mathrm{H}), 1.70(\mathrm{ddd}, J=13.2,9.6,5.0 \mathrm{~Hz}$, $1 \mathrm{H}), 1.21(\mathrm{~d}, J=6.4 \mathrm{~Hz}, 3 \mathrm{H}), 0.91(\mathrm{~d}, J=7.0 \mathrm{~Hz}, 3 \mathrm{H}), 0.88$ (s, 9H), 0.87 (s, 9H), 0.08 (s, 3H), 0.07 (s, 3H), 0.03 (s, 3H), 0.01 (s, 3H); ${ }^{13} \mathrm{C}$ NMR (100 MHz, $\left.\mathrm{CDCl}_{3}\right): \delta 143.12,134.90,120.55$, $117.05,85.73,82.74,81.88,79.86,76.84,77.20,71.01,70.77,67.05,57.45,57.03,43.99,41.28$, $37.33,25.86,25.75,19.30,18.29,18.17,13.04,-4.58,-4.68,-4.75,-4.79$. HRMS (ESI): [M + $\left.\mathrm{NH}_{4}\right]^{+}$calcd. for $\mathrm{C}_{33} \mathrm{H}_{66} \mathrm{O}_{6} \mathrm{NSi}_{2} 628.4423$, found 628.4445 .

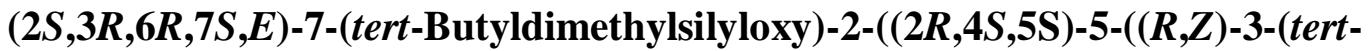

\section{butyldimethylsilyloxy)-2-methylhexa-1,5-dienyl)-4-methoxytetrahydrofuran-2-yl)-6- methoxyoct-4-en-3-ol (9):}

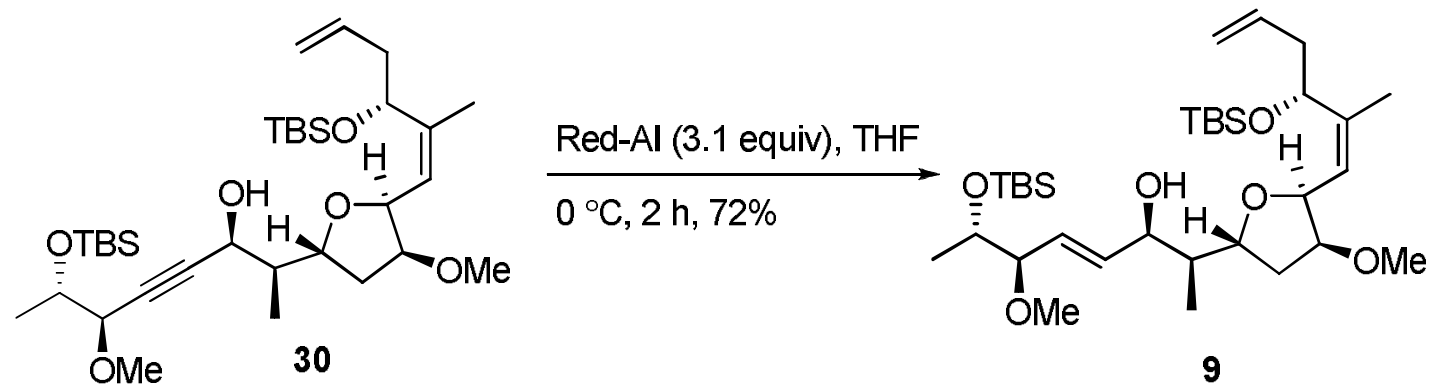

A stirred solution of alcohol $\mathbf{3 0}$ (40 $\mathrm{mg}, 0.065 \mathrm{mmol})$ in anhydrous THF (2 ml) was treated with Red-Al (0.06 ml, $0.2 \mathrm{mmol}, 65 \%$ in toluene) at $0{ }^{\circ} \mathrm{C}$ under argon and stirred for $2 \mathrm{~h}$. The reaction mixture was quenched at $0{ }^{\circ} \mathrm{C}$ with saturated Rochelle salt $(3 \mathrm{ml})$ and diluted with ethyl acetate $(3 \mathrm{ml})$. The reaction mixture was warmed to room temperature and stirred until two clear layers formed. The reaction mixture was diluted with water $(10 \mathrm{ml})$ and the aqueous layer was extracted with ethyl acetate $(3 \times 15 \mathrm{ml})$. The combined organic extracts were washed with water $(10 \mathrm{ml})$ and brine $(10 \mathrm{ml})$. The organic layer was dried over anhydrous sodium sulfate and filtered. The filtrate was concentrated under reduced pressure to give a crude material which was purified by silica gel column chromatography $\left(\mathrm{SiO}_{2}, 100-200\right.$ mesh, $\left.8 \% \mathrm{EtOAc/hexane}\right)$ to afford $9(29 \mathrm{mg}, 0.047 \mathrm{mmol}, 72 \%)$ as a colorless oil. $R_{f}=0.4\left(\mathrm{SiO}_{2}, 20 \% \mathrm{EtOAc} / \mathrm{hexane}\right) ;[\alpha]_{\mathrm{D}}{ }^{25}=$ -10.3 (c 0.35, $\mathrm{CHCl}_{3}$ ); IR (Neat): $v_{\max } 3478,2928,2856,1724,1643,1463,172,1253,1113$, 1078, 1040, 1002, 942, 915, 835, 776, $672 \mathrm{~cm}^{-1} ;{ }^{1} \mathrm{H}$ NMR (400 MHz, $\left.\mathrm{CDCl}_{3}\right): \delta 5.79-5.69(\mathrm{~m}$, 2H), 5.57 (ddd, $J=15.7,7.6,0.9 \mathrm{~Hz}, 1 \mathrm{H}), 5.43(\mathrm{~d}, J=8.8 \mathrm{~Hz}, 1 \mathrm{H}), 5.09-5.01(\mathrm{~m}, 2 \mathrm{H}), 4.70(\mathrm{dd}$, 
$J=9.0,3.7 \mathrm{~Hz}, 1 \mathrm{H}), 4.52(\mathrm{t}, J=6.7 \mathrm{~Hz}, 1 \mathrm{H}), 4.22(\mathrm{~d}, J=4.0 \mathrm{~Hz}, 1 \mathrm{H}), 4.09(\mathrm{dt}, J=9.5,5.7 \mathrm{~Hz}$, 1H), 3.80 (dd, $J=6.1,4.3 \mathrm{~Hz}, 1 \mathrm{H}), 3.76$ (t, $J=4.0 \mathrm{~Hz}, 1 \mathrm{H}), 3.41$ (dd, $J=7.6,4.3 \mathrm{~Hz}, 1 \mathrm{H}), 3.32$ (s, 3H), 3.29 (s, 3H), 2.38-2.18 (m, 3H), $1.82(\mathrm{ddd}, J=9.1,7.0,2.7 \mathrm{~Hz}, 1 \mathrm{H}), 1.75(\mathrm{~d}, J=1.1 \mathrm{~Hz}$, 3H), 1.69 (ddd, $J=13.0,9.7,4.8 \mathrm{~Hz}, 1 \mathrm{H}), 1.11(\mathrm{~d}, J=6.2 \mathrm{~Hz}, 3 \mathrm{H}), 0.87$ (s, 9H), 0.87 (s, 9H), $0.83(\mathrm{~d}, J=7.0 \mathrm{~Hz}, 3 \mathrm{H}), 0.04(\mathrm{~s}, 6 \mathrm{H}), 0.03(\mathrm{~s}, 3 \mathrm{H}), 0.01(\mathrm{~s}, 3 \mathrm{H}) ;{ }^{13} \mathrm{C} \mathrm{NMR}\left(100 \mathrm{MHz}, \mathrm{CDCl}_{3}\right): \delta$ 143.31 , 134.94, 134.20, 129.00, 120.50, 116.99, 86.74, 82.12, 79.97, 76.82, 74.94, 71.00, 70.95, $57.49,56.66,43.90,41.30,37.35,25.86,25.75,19.74,18.29,18.17,18.13,12.35,-4.58,-4.63$, 4.74, -4.79. HRMS (ESI): $[\mathrm{M}+\mathrm{Na}]^{+}$calcd. for $\mathrm{C}_{33} \mathrm{H}_{64} \mathrm{O}_{6} \mathrm{NaSi}_{2} 635.4134$, found 635.4125.

\section{(S)-3-((2E,4S,5S,6E)-5-Hydroxy-7-iodo-2,4,6-trimethylhepta-2,6-dienoyl)-4-}

\section{isopropyloxazolidin-2-one (31):}

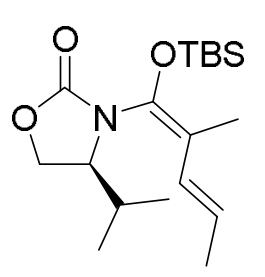

18

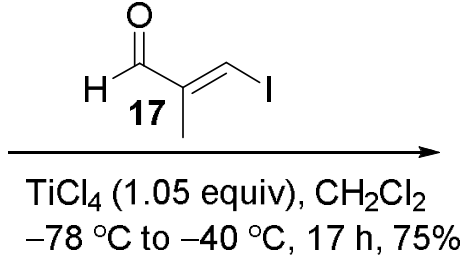

$-78^{\circ} \mathrm{C}$ to $-40^{\circ} \mathrm{C}, 17 \mathrm{~h}, 75 \%$

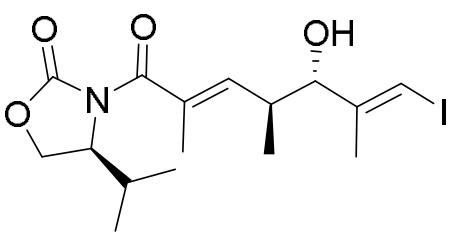

31

A stirred solution of aldehyde $17(866 \mathrm{mg}, 4.42 \mathrm{mmol})$ in anhydrous $\mathrm{CH}_{2} \mathrm{Cl}_{2}(12 \mathrm{ml})$ was treated with a solution of $\mathrm{TiCl}_{4}(1.0 \mathrm{M}$ toluene solution, $2.32 \mathrm{ml}, 2.32 \mathrm{mmol})$ at $-78{ }^{\circ} \mathrm{C}$ under argon atmosphere. The resulting orange solution was stirred for $5 \mathrm{~min}$ and then a solution of compound $18(750 \mathrm{mg}, 2.21 \mathrm{mmol})$ in anhydrous $\mathrm{CH}_{2} \mathrm{Cl}_{2}(10 \mathrm{ml})$ was added to the reaction mixture and stirred for $1 \mathrm{~h}$ at the same temperature. The reaction temperature was then warmed to $-40{ }^{\circ} \mathrm{C}$ and stirred for $16 \mathrm{~h}$. The reaction mixture was quenched with $(1: 1)$ mixture of saturated Rochelle salt and saturated $\mathrm{NaHCO}_{3}(20 \mathrm{ml})$ and the mixture was warmed to room temperature and stirred until two clear layers formed. The reaction mixture was diluted with water $(20 \mathrm{ml})$ and $\mathrm{CH}_{2} \mathrm{Cl}_{2}(20 \mathrm{ml})$ and the aqueous layer was extracted with $\mathrm{CH}_{2} \mathrm{Cl}_{2}(3 \times 30 \mathrm{ml})$. The combined organic extracts were washed with water $(30 \mathrm{ml})$ and brine $(30 \mathrm{ml})$. The organic layer was dried over anhydrous sodium sulfate and filtered. The filtrate was concentrated under reduced pressure to give a crude material which was purified by silica gel column chromatography ( $\mathrm{SiO}_{2}, 100-200 \mathrm{mesh}, 15 \%$ EtOAc/hexane) to afford aldol adduct 31 (698 mg, $1.41 \mathrm{mmol}, 75 \%)$ as a pale yellow solid. $R_{f}=0.4\left(\mathrm{SiO}_{2}, 40 \% \mathrm{EtOAc} / \mathrm{hexane}\right) ;[\alpha]_{\mathrm{D}}{ }^{25}=-15.7(c$ 
$1.2, \mathrm{CHCl}_{3}$ ); IR (Neat): $v_{\max } 3496,2965,2926,2874,1767,1686,1457,1389,1369,1303,1207$, $1012,777,690 \mathrm{~cm}^{-1} ;{ }^{1} \mathrm{H}$ NMR $\left(500 \mathrm{MHz}, \mathrm{CDCl}_{3}\right): \delta 6.25(\mathrm{~s}, 1 \mathrm{H}), 5.71(\mathrm{qd}, J=10.2,1.5 \mathrm{~Hz}$, $1 \mathrm{H}), 4.57(\mathrm{td}, J=9.2,5.3 \mathrm{~Hz}, 1 \mathrm{H}), 4.35(\mathrm{t}, J=9.0 \mathrm{~Hz}, 1 \mathrm{H}), 4.19(\mathrm{dd}, J=9.2,5.6 \mathrm{~Hz}, 1 \mathrm{H}), 3.87$ $(\mathrm{d}, J=9.2 \mathrm{~Hz}, 1 \mathrm{H}), 2.78-2.69(\mathrm{~m}, 1 \mathrm{H}), 2.38-2.30(\mathrm{~m}, 1 \mathrm{H}), 1.97(\mathrm{~d}, J=1.1 \mathrm{~Hz}, 3 \mathrm{H}), 1.87(\mathrm{~d}, J=$ $0.6 \mathrm{~Hz}, 3 \mathrm{H}), 0.93(\mathrm{~d}, J=6.7 \mathrm{~Hz}, 3 \mathrm{H}), 0.91(\mathrm{~d}, J=6.7 \mathrm{~Hz}, 3 \mathrm{H}), 0.85(\mathrm{~d}, J=6.7 \mathrm{~Hz}, 3 \mathrm{H}) ;{ }^{13} \mathrm{C}$ NMR (125 MHz, $\left.\mathrm{CDCl}_{3}\right): \delta$ 171.22, 154.52, 147.21, 140.20, 132.39, 80.84, 80.24, 63.52, 58.08, 38.00, 28.39, 18.81, 17.82, 15.98, 15.17, 14.09. HRMS (ESI):[M + Na $]^{+}$calcd. for $\mathrm{C}_{16} \mathrm{H}_{24} \mathrm{O}_{4} \mathrm{NINa}$ 444.0642 , found 444.0632 .

(S)-3-((2E,4S,5S,6E)-7-Iodo-5-(4-methoxybenzyloxy)-2,4,6-trimethylhepta-2,6-dienoyl)-4isopropyloxazolidin-2-one (32):

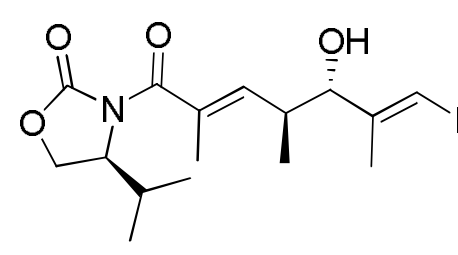

31

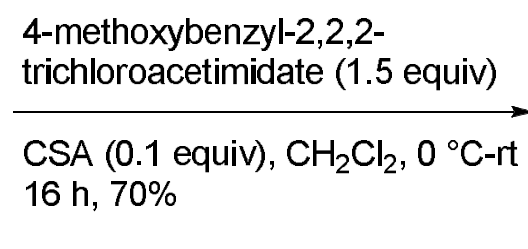

CSA $(0.1$
$16 \mathrm{~h}, 70 \%$

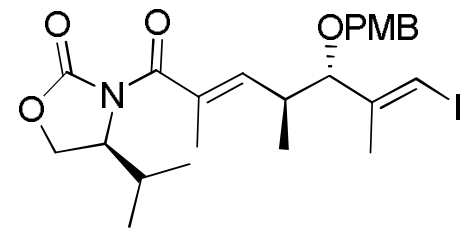

32

A solution of compound $\mathbf{3 1}(570 \mathrm{mg}, 1.35 \mathrm{mmol})$ in anhydrous $\mathrm{CH}_{2} \mathrm{Cl}_{2}(6 \mathrm{ml})$ was treated with 4-methoxybenzyl-2,2,2-trichloroacetimidate $(572 \mathrm{mg}, 2.03 \mathrm{mmol})$ and CSA (31.4 mg, 0.14 $\mathrm{mmol})$ at $0{ }^{\circ} \mathrm{C}$. The solution was warmed to room temperature and stirred for $16 \mathrm{~h}$. The reaction was quenched with saturated aqueous $\mathrm{NaHCO}_{3}(5 \mathrm{ml})$ at $0{ }^{\circ} \mathrm{C}$ and diluted with water $(10 \mathrm{ml})$. The layers were separated and the aqueous layer was extracted with $\mathrm{CH}_{2} \mathrm{Cl}_{2}(3 \times 20 \mathrm{ml})$ three times. The organic extracts were washed with water $(20 \mathrm{ml})$ and brine $(20 \mathrm{ml})$. The organic layer was dried over anhydrous sodium sulfate and filtered. The filtrate was concentrated under reduced pressure to give a crude material which was purified by silica gel column chromatography ( $\mathrm{SiO}_{2}, 100-200$ mesh, 10\% EtOAc/hexane) to afford $32(513 \mathrm{mg}, 0.95 \mathrm{mmol}, 70$ $\%)$ as a brown liquid. $R_{f}=0.45\left(\mathrm{SiO}_{2}, 40 \% \mathrm{EtOAc} /\right.$ hexane $) ;[\alpha]_{\mathrm{D}}{ }^{25}=-7.0\left(\right.$ c 1.14, $\left.\mathrm{CHCl}_{3}\right)$; IR (Neat): $v_{\max } 2963,2926,2868,1783,1731,1681,1612,1511,1459,1369,1301,1274,1245$, 1206, 1064, 1033, 823, 755, $690 \mathrm{~cm}^{-1} ;{ }^{1} \mathrm{H}$ NMR $\left(400 \mathrm{MHz}, \mathrm{CDCl}_{3}\right): \delta 7.22(\mathrm{~m}, 2 \mathrm{H}), 6.85(\mathrm{~m}$, 2H), $6.18(\mathrm{~d}, J=1.2 \mathrm{~Hz}, 1 \mathrm{H}), 5.81(\mathrm{qd}, J=9.5,1.5 \mathrm{~Hz}, 1 \mathrm{H}), 4.50(\mathrm{td}, J=9.0,4.5 \mathrm{~Hz}, 1 \mathrm{H}), 4.40$ (d, $J=11.5 \mathrm{~Hz}, 1 \mathrm{H}), 4.31$ (t, $J=8.9 \mathrm{~Hz}, 1 \mathrm{H}), 4.2-4.14(\mathrm{~m}, 2 \mathrm{H}), 3.80$ (s, $3 \mathrm{H}), 3.62(\mathrm{~d}, J=8.1 \mathrm{~Hz}$, $1 \mathrm{H}), 2.79-2.69(\mathrm{~m}, 1 \mathrm{H}), 2.43-2.34(\mathrm{~m}, 1 \mathrm{H}), 1.91(\mathrm{~d}, J=1.3 \mathrm{~Hz}, 3 \mathrm{H}), 1.81(\mathrm{~d}, J=1.0 \mathrm{~Hz}, 3 \mathrm{H})$, 
$0.92(\mathrm{~d}, J=7.0 \mathrm{~Hz}, 3 \mathrm{H}), 0.90(\mathrm{~d}, J=6.8 \mathrm{~Hz}, 3 \mathrm{H}), 0.84(\mathrm{~d}, J=6.8 \mathrm{~Hz}, 3 \mathrm{H}) ;{ }^{13} \mathrm{C} \mathrm{NMR}(100 \mathrm{MHz}$, $\left.\mathrm{CDCl}_{3}\right): \delta 171.66,159.02,153.41,146.64,140.67,131.58,130.19,129.49,113.61,86.79,80.29$, $70.04,63.36,58.30,55.21,35.89,28.26,17.85,16.07,14.95,14.15$. HRMS (ESI): [M + $\mathrm{Na}]^{+}$calcd. for $\mathrm{C}_{24} \mathrm{H}_{32} \mathrm{O}_{5} \mathrm{NINa}$ 564.1217, found 564.1207.

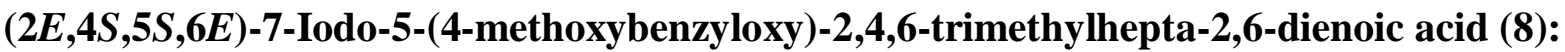

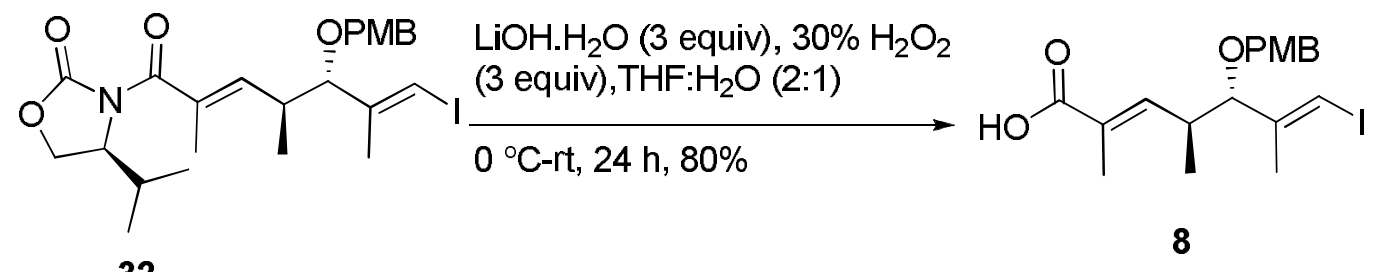

32

A stirred solution of $32(480 \mathrm{mg}, 0.89 \mathrm{mmol})$ in THF: $\mathrm{H}_{2} \mathrm{O}(12 \mathrm{ml}, 2: 1)$ was treated with $30 \% \mathrm{H}_{2} \mathrm{O}_{2}$ in $\mathrm{H}_{2} \mathrm{O}(0.3 \mathrm{ml}, 2.67 \mathrm{mmol})$ and $\mathrm{LiOH} \cdot \mathrm{H}_{2} \mathrm{O}(37.3 \mathrm{mg}, 2.67 \mathrm{mmol})$ ) at $0{ }^{\circ} \mathrm{C}$. The resulting reaction mixture was warmed to room temperature and stirred for $24 \mathrm{~h}$. The reaction mixture was acidified with $1 \mathrm{~N} \mathrm{HCl}$ (until $\mathrm{pH}=3$ ) and diluted with water (10 ml) and ethyl acetate $(10 \mathrm{ml})$. The layers were separated and the aqueous layer was extracted with ethyl acetate ( 3 x $20 \mathrm{ml})$. The combined organic extracts were washed with water $(20 \mathrm{ml})$ and brine $(20 \mathrm{ml})$. The organic layer was dried over anhydrous sodium sulfate and filtered. The filtrate was concentrated under reduced pressure to give a crude material which was purified by silica gel column chromatography $\left(\mathrm{SiO}_{2}, 100-200\right.$ mesh, 15\% EtOAc/hexane) to afford dienoic acid 8 (305 $\mathrm{mg}, 0.72 \mathrm{mmol}, 80 \%)$ as a colorless oil. $R_{f}=0.3\left(\mathrm{SiO}_{2}, 40 \%\right.$ EtOAc/hexane $) ;[\alpha]_{\mathrm{D}}{ }^{25}=-41.8(c$ 0.85, $\mathrm{CHCl}_{3}$ ); IR (Neat): $v_{\max }$ 3745, 2960, 2858, 2310, 1685, 1647, 1612, 1511, 1455, 1421, 1382, 1246, 1172, 1067, 1034, 999, 820, $676 \mathrm{~cm}^{-1} ;{ }^{1} \mathrm{H}$ NMR (500 MHz, $\left.\mathrm{CDCl}_{3}\right): \delta 7.17(\mathrm{~m}, 2 \mathrm{H})$, $6.86(\mathrm{~m}, 2 \mathrm{H}), 6.72(\mathrm{qd}, J=9.8,1.6 \mathrm{~Hz}, 1 \mathrm{H}), 6.20(\mathrm{~d}, J=0.8 \mathrm{~Hz}, 1 \mathrm{H}), 4.42(\mathrm{~d}, J=11.7 \mathrm{~Hz}, 1 \mathrm{H})$, $4.12(\mathrm{~d}, J=11.7 \mathrm{~Hz}, 1 \mathrm{H}), 3.80(\mathrm{~s}, 3 \mathrm{H}), 3.63(\mathrm{~d}, J=8.5 \mathrm{~Hz}, 1 \mathrm{H}), 2.78-2.72(\mathrm{~m}, 1 \mathrm{H}), 1.86(\mathrm{~d}, J=$ $1.2 \mathrm{H}, 3 \mathrm{H}), 1.81(\mathrm{~d}, J=1.1 \mathrm{~Hz}, 3 \mathrm{H}), 0.84(\mathrm{~d}, J=6.7 \mathrm{~Hz}, 3 \mathrm{H}) ;{ }^{13} \mathrm{C} \mathrm{NMR}\left(125 \mathrm{MHz}, \mathrm{CDCl}_{3}\right): \delta$ $173.00,159.14,147.26,146.36,129.85,129.30,127.35,113.76,86.83,80.58,69.97,55.24$, 36.42, 19.02, 16.07, 12.41. HRMS (ESI): $\left[\mathrm{M}+\mathrm{NH}_{4}\right]^{+}$calcd. for $\mathrm{C}_{18} \mathrm{H}_{27} \mathrm{O}_{4} \mathrm{NI}$ 448.0979, found 448.0992 . 
$(2 E, 4 S, 5 S, 6 E)-((2 R, 3 R, 6 R, 7 S, E)-7-(t e r t-B u t y l d i m e t h y l s i l y l o x y)-2-((2 R, 4 S, 5 S)-5-((R, Z)-3-$ (tert-butyldimethylsilyloxy)-2-methylhexa-1,5-dienyl)-4-methoxytetrahydrofuran-2-yl)-6methoxyoct-4-en-3-yl) 7-iodo-5-(4-methoxybenzyloxy)-2,4,6-trimethylhepta-2,6-dienoate (33)

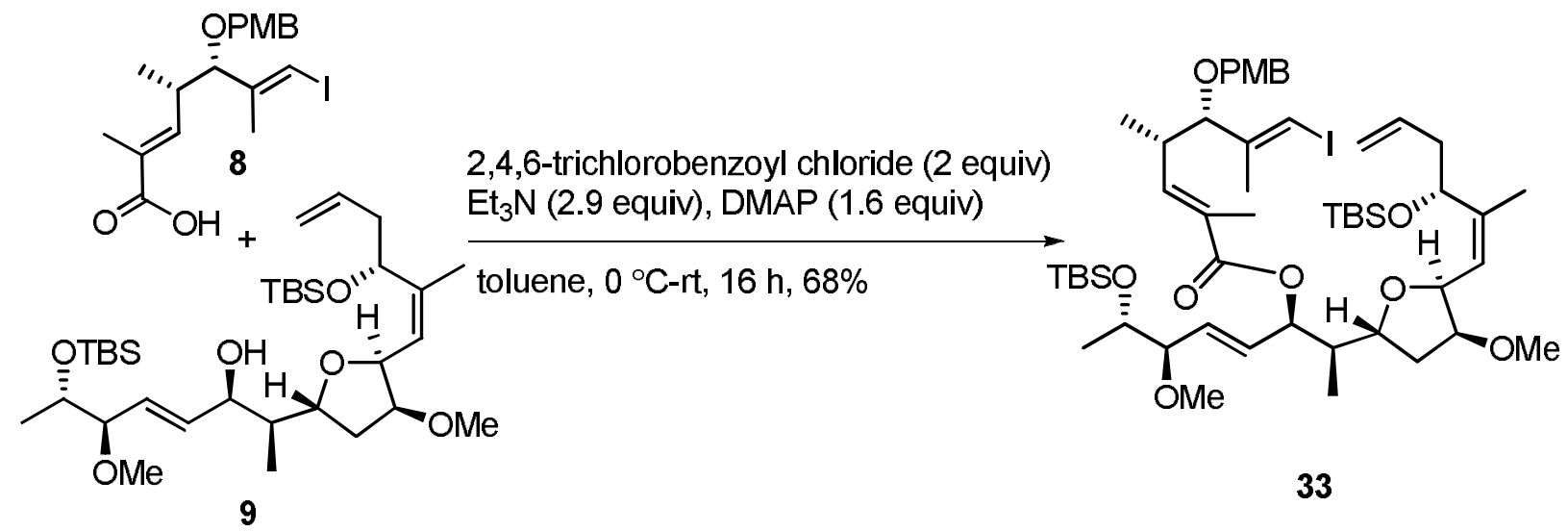

A stirred solution of alcohol $9(23 \mathrm{mg}, 0.038 \mathrm{mmol})$ and dienoicacid $8(24.2 \mathrm{mg}, 0.056$ mmol) in anhydrous toluene $(1.5 \mathrm{ml})$ was treated with $\mathrm{Et}_{3} \mathrm{~N}(16 \mu \mathrm{l}, 0.11 \mathrm{mmol})$, DMAP $(7 \mathrm{mg}$, $0.06 \mathrm{mmol})$ and 2,4,6-tricholobenzoyl chloride $(12 \mu \mathrm{l}, 0.076 \mathrm{mmol})$ at $0{ }^{\circ} \mathrm{C}$. The resulting white suspension was stirred at room temperature for $16 \mathrm{~h}$. The reaction was quenched with saturated aqueous $\mathrm{NaHCO}_{3}(2 \mathrm{ml})$ at $0{ }^{\circ} \mathrm{C}$ and diluted with water $(2 \mathrm{ml})$. The reaction mixture was extracted with ethyl acetate $(3 \times 15 \mathrm{ml})$ and the combined organic extracts were washed with water $(15 \mathrm{ml})$ and brine $(15 \mathrm{ml})$. The organic layer was dried over anhydrous sodium sulfate and filtered. The filtrate was concentrated under reduced pressure to give a crude material which was purified by silica gel column chromatography (5\% EtOAc/hexane) to afford ester 33 (26 mg, $0.025 \mathrm{mmol}, 68 \%)$ as a colorless oil. $R_{f}=0.7\left(\mathrm{SiO}_{2}, 20 \%\right.$ EtOAc/hexane); $[\alpha]_{\mathrm{D}}{ }^{25}=-22.1(c 0.7$, $\mathrm{CHCl}_{3}$ ); IR (Neat): $v_{\max } 2925,2854,1715,1614,1462,1374,1253,1112,1077,834,777 \mathrm{~cm}^{-1}$; ${ }^{1} \mathrm{H}$ NMR (400 MHz, $\left.\mathrm{CDCl}_{3}\right): \delta 7.15(\mathrm{~m}, 2 \mathrm{H}), 6.85(\mathrm{~m}, 2 \mathrm{H}), 6.58(\mathrm{dd}, J=9.5,1.3 \mathrm{~Hz}, 1 \mathrm{H}), 6.16$ $(\mathrm{d}, J=0.6 \mathrm{~Hz}, 1 \mathrm{H}), 5.83(\mathrm{ddt}, J=17.2,10.1,7.1 \mathrm{~Hz}, 1 \mathrm{H}), 5.63(\mathrm{dd}, J=15.8,5.5 \mathrm{~Hz}, 1 \mathrm{H}), 5.57-$ $5.43(\mathrm{~m}, 3 \mathrm{H}), 5.13-5.01(\mathrm{~m}, 2 \mathrm{H}), 4.58-4.51(\mathrm{~m}, 2 \mathrm{H}), 4.41(\mathrm{~d}, J=11.7 \mathrm{~Hz}, 1 \mathrm{H}), 4.12(\mathrm{~d}, J=11.9$ $\mathrm{Hz}, 2 \mathrm{H}), 3.79$ (s, 3H), 3.78-3.75 (m, 2H), $3.62(\mathrm{~d}, J=8.3 \mathrm{~Hz}, 1 \mathrm{H}), 3.40(\mathrm{dd}, J=7.0,4.2 \mathrm{~Hz}, 1 \mathrm{H})$, $3.3(\mathrm{~s}, 3 \mathrm{H}), 3.28(\mathrm{~s}, 3 \mathrm{H}), 2.78-2.67(\mathrm{~m}, 1 \mathrm{H}), 2.39-2.21(\mathrm{~m}, 2 \mathrm{H}), 2.12(\mathrm{dd}, J=13.0,6.7 \mathrm{~Hz}, 1 \mathrm{H})$, $1.94(\mathrm{dt}, J=7.2,3.8 \mathrm{~Hz}, 1 \mathrm{H}), 1.83(\mathrm{~d}, J=1.2 \mathrm{~Hz}, 3 \mathrm{H}), 1.79(\mathrm{~d}, J=0.9 \mathrm{~Hz}, 3 \mathrm{H}), 1.73(\mathrm{~d}, J=1.2$ $\mathrm{Hz}, 3 \mathrm{H}), 1.71-1.64(\mathrm{~m}, 1 \mathrm{H}), 1.08(\mathrm{~d}, J=6.4 \mathrm{~Hz}, 3 \mathrm{H}), 0.94(\mathrm{~d}, J=7.0 \mathrm{~Hz}, 3 \mathrm{H}), 0.88(\mathrm{~s}, 9 \mathrm{H}), 0.86$ 
$(\mathrm{s}, 9 \mathrm{H}), 0.82(\mathrm{~d}, J=6.8 \mathrm{~Hz}, 3 \mathrm{H}), 0.03(\mathrm{~s}, 3 \mathrm{H}), 0.02(\mathrm{~s}, 6 \mathrm{H}), 0.001(\mathrm{~s}, 3 \mathrm{H}) ;{ }^{13} \mathrm{C} \mathrm{NMR}(100 \mathrm{MHz}$, $\left.\mathrm{CDCl}_{3}\right): \delta 166.76,159.09,146.53,144.32,143.81,135.58,131.66,129.89,129.66,129.23$, 128.36, 120.34, 116.64, 113.73, 86.74, 86.37, 82.90, 80.42, 77.67, 76.43, 74.04, 71.30, 70.90, 69.91, 57.29, 56.94, 55.21, 42.67, 41.34, 36.19, 34.39, 25.86, 25.77, 19.52, 19.09, 18.18, 18.09, 16.25, 12.88, 9.04, -4.65, -4.74, -4.77. HRMS (ESI): $\left[\mathrm{M}+\mathrm{NH}_{4}\right]^{+}$calcd. for $\mathrm{C}_{51} \mathrm{H}_{89} \mathrm{O}_{9} \mathrm{NISi}_{2}$ 1042.5115, found 1042.5117 .

$(2 E, 4 S, 5 S, 6 E)-((2 R, 3 R, 6 R, 7 S, E)-7-(t e r t-B u t y l d i m e t h y l s i l y l o x y)-2-((2 R, 4 S, 5 S)-5-((R, Z)-3-$ (tert-butyldimethylsilyloxy)-2-methylhexa-1,5-dienyl)-4-methoxytetrahydrofuran-2-yl)-6methoxyoct-4-en-3-yl)5-hydroxy-7-iodo-2,4,6-rimethylhepta-2,6-dienoate (7):

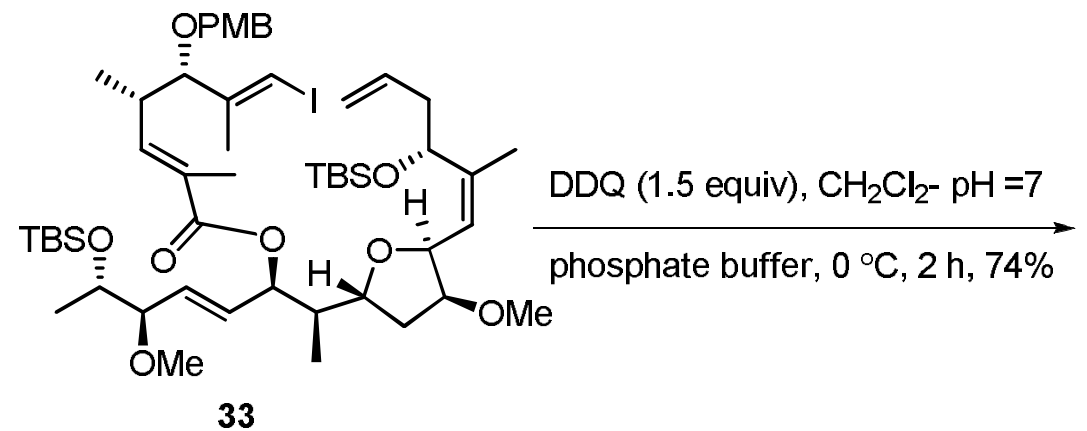

33

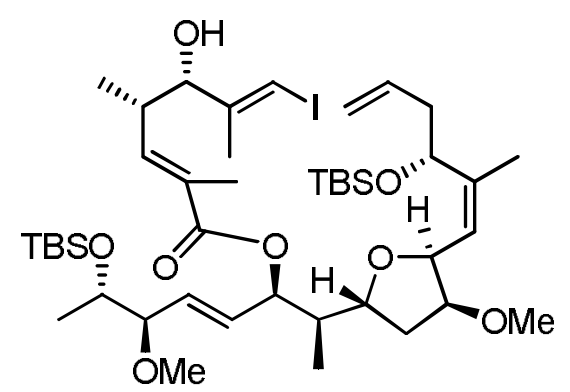

7

To a stirred solution of compound $33(23 \mathrm{mg}, 0.022 \mathrm{mmol})$ in $\mathrm{CH}_{2} \mathrm{Cl}_{2}$ and $\mathrm{pH}=7$ phosphate buffer $(12 \mathrm{ml}, 5: 1)$ was added DDQ $(7.5 \mathrm{mg}, 0.033 \mathrm{mmol})$ at $0{ }^{\circ} \mathrm{C}$ and stirred for $2 \mathrm{~h}$. The reaction was quenched with saturated aqueous $\mathrm{NaHCO}_{3}(5 \mathrm{ml})$ at $0{ }^{\circ} \mathrm{C}$ and diluted with water $(5 \mathrm{ml})$. The layers were separated and the aqueous layer was extracted with $\mathrm{CH}_{2} \mathrm{Cl}_{2}(3 \times 15$ $\mathrm{ml})$. The combined organic extracts were washed with water $(15 \mathrm{ml})$ and brine $(15 \mathrm{ml})$. The organic layer was dried over anhydrous sodium sulfate and filtered. The filtrate was concentrated under reduced pressure to give a crude material which was purified by silica gel column chromatography $\left(\mathrm{SiO}_{2}, 10 \%\right.$ EtOAc/hexane) to afford alcohol 7 (15 mg, $\left.0.017 \mathrm{mmol}, 74 \%\right)$ as a brown oil. $R_{f}=0.45\left(\mathrm{SiO}_{2}, 20 \% \mathrm{EtOAc} /\right.$ hexane $) ;[\alpha]_{\mathrm{D}}{ }^{25}=-14.9\left(c 0.38, \mathrm{CHCl}_{3}\right)$; IR (Neat): $v_{\max }$ 3450, 2926, 2855, 1713, 1647,1462, 1378, 1255, 1222, 1114, 1077, 1005, 835, 777, $672 \mathrm{~cm}^{-1} ;{ }^{1} \mathrm{H}$ NMR (400 MHz, $\left.\mathrm{CDCl}_{3}\right): \delta 6.59(\mathrm{dd}, J=10.0,1.5 \mathrm{~Hz}, 1 \mathrm{H}), 6.29$ (s, 1H), 5.82 (ddt, $J=17.2$, 10.1, 7.1 Hz, 1H), 5.65-5.43 (m, 4H), 5.13-5.01 (m, 2H), 4.58-4.50 (m, 2H), 4.09-3.98 (m, 2H), 3.82-3.75 (m, 2H), $3.39(\mathrm{dd}, J=7.2,4.4 \mathrm{~Hz}, 1 \mathrm{H}), 3.32(\mathrm{~s}, 3 \mathrm{H}), 3.28(\mathrm{~s}, 3 \mathrm{H}), 2.76-2.67$ (m, 1H), 
2.38-2.21 (m, 2H), $2.15(\mathrm{dd}, J=12.0,7.0 \mathrm{~Hz}, 1 \mathrm{H}), 1.94-1.90(\mathrm{~m}, 1 \mathrm{H}), 1.88(\mathrm{~d}, J=1.3 \mathrm{~Hz}, 3 \mathrm{H})$, $1.84(\mathrm{~d}, J=0.9 \mathrm{~Hz}, 3 \mathrm{H}), 1.74(\mathrm{~d}, J=1.1 \mathrm{~Hz}, 3 \mathrm{H}), 1.72-1.64(\mathrm{~m}, 1 \mathrm{H}), 1.08(\mathrm{~d}, J=6.2 \mathrm{~Hz}, 3 \mathrm{H})$, $0.92(\mathrm{~d}, J=7.0 \mathrm{~Hz}, 3 \mathrm{H}), 0.91(\mathrm{~d}, J=6.1 \mathrm{~Hz}, 3 \mathrm{H}), 0.88(\mathrm{~s}, 9 \mathrm{H}), 0.86(\mathrm{~s}, 9 \mathrm{H}), 0.03(\mathrm{~s}, 6 \mathrm{H}), 0.02$ (s, 3H), $0.01(\mathrm{~s}, 3 \mathrm{H}) ;{ }^{13} \mathrm{C} \mathrm{NMR}\left(100 \mathrm{MHz}, \mathrm{CDCl}_{3}\right): \delta 166.53,147.96,143.98,142.95,135.61$, 131.42, 129.88, 129.60, 120.22, 116.62, 86.37, 82.90, 80.73, 80.15, 77.61, 76.40, 74.18, 71.31, 70.90, 57.33, 56.96, 42.82, 41.33, 37.43, 34.75, 25.86, 25.78, 19.63, 19.27, 18.20, 18.09 16.41, 12.97, 9.17, -4.63, -4.74, -4.76. HRMS (ESI): $[\mathrm{M}+\mathrm{Na}]^{+}$calcd. for $\mathrm{C}_{43} \mathrm{H}_{77} \mathrm{O}_{8} \mathrm{INaSi}_{2} 927.4094$, found 927.4094 .

$(1 R, 2 R, 3 R, 6 E, 8 S, 10 E, 12 E, 15 R, 16 Z, 18 S, 19 S)-15$-(tert-Butyldimethylsilyloxy)-3-((3R,4S,E)-4(tert-butyldimethylsilyloxy)-3-methoxypent-1-enyl)-19-methoxy-2,6,8,10,16-pentamethyl4,21-dioxabicyclo[16.2.1]henicosa-6,10,12,16-tetraene-5,9-dione (34):

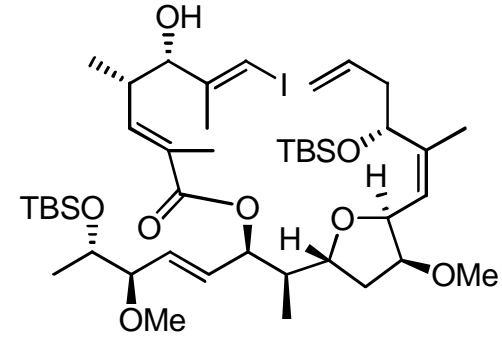

7
(1) $\mathrm{Pd}(\mathrm{OAc})_{2}$ (1.5 equiv), $\mathrm{Cs}_{2} \mathrm{CO}_{3}(1.7$ equiv) $\mathrm{Et}_{3} \mathrm{~N}$ (1.2 equiv), DMF, rt, $6 \mathrm{~h}$

(2) $\mathrm{MnO}_{2}$ (6 equiv), hexane, $0^{\circ} \mathrm{C}-\mathrm{rt}, 16 \mathrm{~h}$ $55 \%$ over two steps

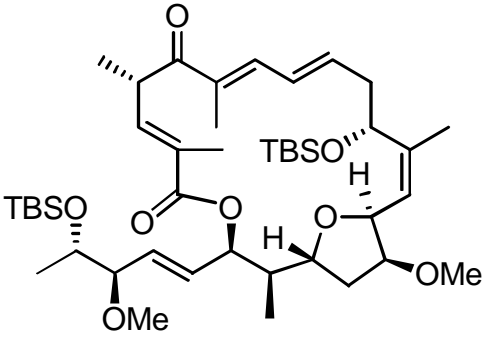

34

A stirred solution of alcohol $7(5.0 \mathrm{mg}, 0.0055 \mathrm{mmol})$ in anhydrous DMF $(3 \mathrm{ml})$ was degassed by purging argon for $45 \mathrm{~min}$. To the solution was added $\mathrm{Cs}_{2} \mathrm{CO}_{3}(3.06 \mathrm{mg}, 0.0094$ $\mathrm{mmol}), \mathrm{Et}_{3} \mathrm{~N}(0.92 \mu \mathrm{l}, 0.0066 \mathrm{mmol})$ followed by $\mathrm{Pd}(\mathrm{OAc})_{2}(1.86 \mathrm{mg}, 0.0083 \mathrm{mmol})$ at room temperature and stirred for $6 \mathrm{~h}$. The reaction was quenched with water $(5 \mathrm{ml})$ at $0{ }^{\circ} \mathrm{C}$ and diluted with ethyl acetate $(5 \mathrm{ml})$. The layers were separated and the aqueous layer was extracted with ethyl acetate $(3 \times 15 \mathrm{ml})$ three times. The combined organic extracts were washed with water (15 $\mathrm{ml})$ and brine $(15 \mathrm{ml})$. The organic layer was dried over anhydrous sodium sulfate and filtered. The filtrate was concentrated under reduced pressure to give a crude material which was passed through a silica gel column $\left(\mathrm{SiO}_{2}, 100-200\right.$ mesh, 15\% EtOAc/hexane) and concentrated. The cyclized product thus obtained was dissolved in hexane and treated with freshly prepared activated $\mathrm{MnO}_{2}(2.9 \mathrm{mg}, 0.033 \mathrm{mmol})$ at $0{ }^{\circ} \mathrm{C}$. The solution was warmed to room temperature and stirred in the dark for $16 \mathrm{~h}$. The reaction mixture was filtered through small Celite plug and 
washed with ethyl acetate $(3 \times 10 \mathrm{ml})$. Combined filtrate and washings was concentrated under reduced pressure to give a crude material which was purified by silica gel column chromatography ( $\mathrm{SiO}_{2}, 100-200$ mesh, 6\% EtOAc/hexane) to afford ketone 34 (2.35 mg, 0.0030 mmol, 55\%) as a colorless oil. $R_{f}=0.5\left(\mathrm{SiO}_{2}, 15 \%\right.$ EtOAc/hexane $) ;[\alpha]_{\mathrm{D}}{ }^{25}=-22.0(c 0.05$, $\mathrm{C}_{6} \mathrm{H}_{6}$ ); IR (Neat): $v_{\max } 2925,2855,1734,1715,1670,1638,1461,1378,1284,1251,1160,1111$, $1075,837,749 \mathrm{~cm}^{-1} ;{ }^{1} \mathrm{H}$ NMR $\left(500 \mathrm{MHz}, \mathrm{CDCl}_{3}\right): \delta 6.88(\mathrm{~d}, J=10.8 \mathrm{~Hz}, 1 \mathrm{H}), 6.39(\mathrm{ddd}, J=$ $14.5,11.0,4.5 \mathrm{~Hz}, 1 \mathrm{H}), 5.92-5.84(\mathrm{~m}, 3 \mathrm{H}), 5.66(\mathrm{~d}, J=8.2 \mathrm{~Hz}, 1 \mathrm{H}), 5.53(\mathrm{dd}, J=5.0,2.3 \mathrm{~Hz}$, $1 \mathrm{H}), 4.57(\mathrm{dt}, J=11.1,4.6 \mathrm{~Hz}, 2 \mathrm{H}), 4.15(\mathrm{ddd}, J=10.8,8.7,4.6 \mathrm{~Hz}, 1 \mathrm{H}), 3.91(\mathrm{dt}, J=6.3,4.1$ $\mathrm{Hz}, 1 \mathrm{H}), 3.79(\mathrm{dt}, J=13.0,6.5 \mathrm{~Hz}, 1 \mathrm{H}), 3.52(\mathrm{t}, J=4.1 \mathrm{~Hz}, 1 \mathrm{H}), 3.28(\mathrm{dd}, J=6.3,4.1 \mathrm{~Hz}, 1 \mathrm{H})$, $3.22(\mathrm{~s}, 3 \mathrm{H}), 2.98(\mathrm{~s}, 3 \mathrm{H}), 2.61(\mathrm{t}, J=13.0 \mathrm{~Hz}, 1 \mathrm{H}), 2.41(\mathrm{ddd}, J=14,11.5,4.4 \mathrm{~Hz}, 1 \mathrm{H}), 2.24-$ $2.07(\mathrm{~m}, 2 \mathrm{H}), 2.06(\mathrm{~d}, J=1.4 \mathrm{~Hz}, 3 \mathrm{H}), 1.79(\mathrm{~s}, 3 \mathrm{H}), 1.78(\mathrm{~s}, 3 \mathrm{H}), 1.63-1.55(\mathrm{~m}, 1 \mathrm{H}), 1.54-1.46$ (m, 1H), $1.19(\mathrm{~d}, J=6.6 \mathrm{~Hz}, 3 \mathrm{H}), 1.16(\mathrm{~d}, J=6.3 \mathrm{~Hz}, 3 \mathrm{H}), 1.02(\mathrm{~s}, 9 \mathrm{H}), 1.00(\mathrm{~s}, 9 \mathrm{H}), 0.78(\mathrm{~d}, J=$ $7.2 \mathrm{~Hz}, 3 \mathrm{H}), 0.16$ (s, 3H), 0.15 (s, 3H), 0.12 (s, 3H), 0.09 (s, 3H); ${ }^{13} \mathrm{C} \mathrm{NMR}\left(125 \mathrm{MHz}, \mathrm{CDCl}_{3}\right)$ : $\delta$ 199.35, 166.73, 142.46, 139.31, 138.13, 136.25, 134.47, 131.55, 129.59, 129.35, 129.16, $127.32,86.92,82.74,78.93,78.80,71.30,70.70,56.72,56.49,41.66,41.27,40.37,36.90,32.32$, $26.12,25.92,23.10,20.56,18.37,18.23,15.36,14.35,14.03,-4.29,-4.40,-4.48,-4.64$. HRMS (ESI): $\left[\mathrm{M}+\mathrm{NH}_{4}\right]^{+}$calcd. for $\mathrm{C}_{43} \mathrm{H}_{74} \mathrm{O}_{8} \mathrm{NaSi}_{2}$ 797.4814, found 797.4809.

\section{Maltepolide C (3):}
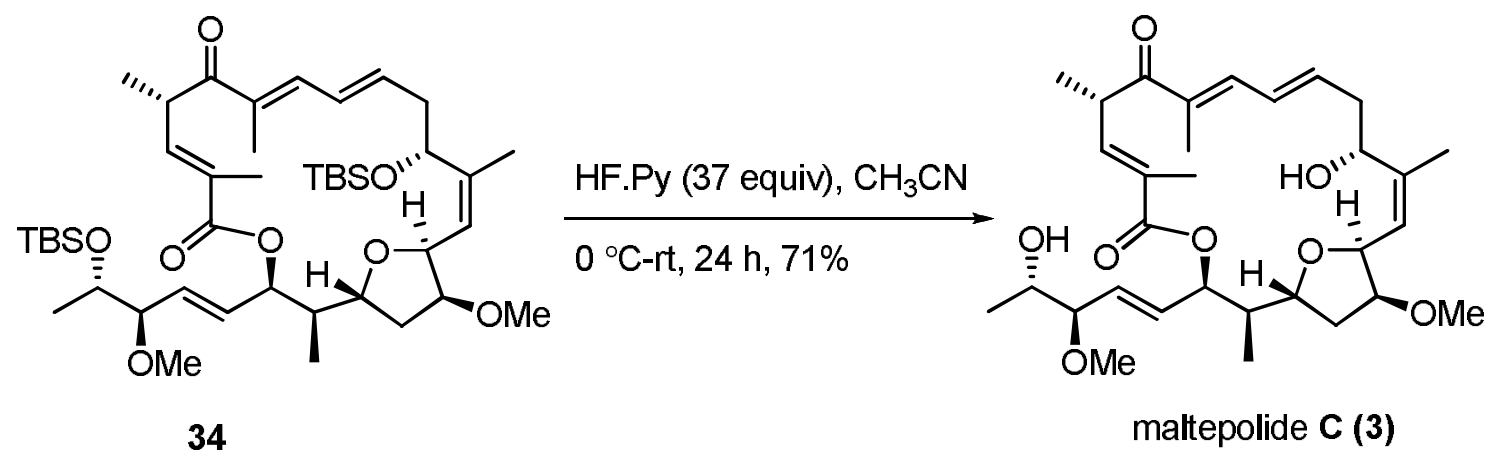

A stirred solution of ketone $34(2.0 \mathrm{mg}, 0.0026 \mathrm{mmol})$ in dry acetonitrile $(2 \mathrm{ml})$ was treated with HF.Py complex $(2.7 \mu 1,0.096 \mathrm{mmol})$ at $0{ }^{\circ} \mathrm{C}$ and the solution was warmed to room temperature and stirred for $24 \mathrm{~h}$. The reaction was quenched with saturated aqueous $\mathrm{NaHCO}_{3}(2$ $\mathrm{ml})$ at $0{ }^{\circ} \mathrm{C}$ and stirred for $30 \mathrm{~min}$. and diluted with water $(3 \mathrm{ml})$. The aqueous layer was extracted with ethyl acetate $(3 \times 15 \mathrm{ml})$. The organic extracts were washed with water $(10 \mathrm{ml})$ 
and brine $(10 \mathrm{ml})$. The organic layer was dried over anhydrous sodium sulfate and filtered. The filtrate was concentrated under reduced pressure to give a crude material which was purified by silica gel column chromatography $\left(\mathrm{SiO}_{2}, 100-200 \mathrm{mesh}, 10 \% \mathrm{MeOH} / \mathrm{CHCl}_{3}\right)$ to afford maltepolide C (3) (1.0 mg, $0.00183 \mathrm{mmol}, 71 \%)$ as colorless oil. $R_{f}=0.4\left(\mathrm{SiO}_{2}, 3 \%\right.$ $\left.\mathrm{MeOH} / \mathrm{CHCl}_{3}\right)$.

$[\alpha]_{\mathrm{D}}^{25}=+40.0\left(c 0.05, \mathrm{CH}_{3} \mathrm{CN}\right) ; v_{\max } 3395,2924,1702,1668,1635,1546,1520,1458,1387$, 1280, 1242, 1105, 974, 750, 692, $7 \mathrm{~cm}^{-1}$; For ${ }^{1} \mathrm{H}$ and ${ }^{13} \mathrm{C}$ chemical shifts $(\delta)$ and coupling constants $\left(J_{\mathrm{H}-\mathrm{H}}\right)$ see table $7(\mathrm{~S} 30-\mathrm{S} 31)$

\section{NMR and molecular dynamics (MD) studies of synthetic maltepolide C (3)}

The structure of synthetic maltepolide (3) is confirmed by extensive NMR experiments including 2-D Double Quantum Filtered Correlation Spectroscopy (DQF-COSY), Nuclear Overhauser Effect Spectroscopy (NOESY), Hetero-nuclear Single Quantum Correlations (HSQC) and Hetero-nuclear Multiple Bond Correlation (HMBC) experiments. The ${ }^{1} \mathrm{H}$ and ${ }^{13} \mathrm{C}$ one dimensional experiments were carried out on $\mathrm{a} \sim 2 \mathrm{mM}$ solution, where as the 2-D experiments were undertaken in $\mathrm{a} \sim 4 \mathrm{mM}$ solution in $\mathrm{CD}_{3} \mathrm{OD}$ at $298 \mathrm{~K}$.

As discussed in the main text, we observed chemical shift differences in the ${ }^{13} \mathrm{C}$ and ${ }^{1} \mathrm{H}$ spectra of $\mathbf{3}$ in the methoxy region $\left({ }^{13} \mathrm{C}\right.$ chemical shifts $(\delta)$ listed in Table 1 and ${ }^{1} \mathrm{H}$ chemical shifts $(\delta)$ listed in Table 2) Therefore detailed NMR studies were carried out to find out possible structural differences in the synthesized molecule $\mathbf{3}$ and isolated maltepolide $\mathrm{C}$.

Table 1: Comparison of ${ }^{13} \mathrm{C}$ chemical shifts ${ }^{*}$ (listed in order of decreasing $\delta$ values) of isolated $(125 \mathrm{Mz})$ and synthetic maltepolide C (3) ( $2 \mathrm{mM}, 293 \mathrm{~K}, 175 \mathrm{MHz})$ in $\mathrm{MeOH}-\mathrm{d}_{4}$

\begin{tabular}{|c|c|c|c|c|c|}
\hline S.No & $\begin{array}{c}\text { Maltepolide C } \\
\text { (isolated) }(\mathrm{ppm})\end{array}$ & $\begin{array}{c}\text { Maltepolide C (3) } \\
\text { (synthetic) }(\mathrm{ppm})\end{array}$ & S.No & $\begin{array}{c}\text { Maltepolide C } \\
\text { (isolated) (ppm) }\end{array}$ & $\begin{array}{c}\text { Maltepolide C (3) } \\
\text { (synthetic) (ppm) }\end{array}$ \\
\hline 1 & 202.8 & 202.70 & 17 & 79.6 & 79.46 \\
\hline 2 & 168.7 & 168.66 & 18 & 70.5 & 70.50 \\
\hline 3 & 143.4 & 143.27 & 19 & 70.3 & 70.28 \\
\hline 4 & 142.3 & 142.14 & 20 & 57.9 & 57.78 \\
\hline 5 & 141.0 & 140.90 & 21 & 57.9 & 57.06 \\
\hline 6 & 137.7 & 137.66 & 22 & 42.9 & 42.76 \\
\hline 7 & 134.5 & 134.35 & 23 & 42.3 & 39.17 \\
\hline 8 & 132.2 & 132.04 & 24 & 39.2 & 38.55 \\
\hline 9 & 131.0 & 130.86 & 25 & 38.7 & 18.92 \\
\hline 10 & 129.7 & 129.59 & 26 & 19.0 & 16.90 \\
\hline 11 & 129.7 & 129.55 & 27 & 17.1 & 15.39 \\
\hline 12 & 129.0 & 128.85 & 28 & 15.6 & \\
\hline
\end{tabular}




\begin{tabular}{|l|l|l|l|l|l|}
\hline 13 & 87.5 & 87.54 & 29 & 14.4 & 14.20 \\
\hline 14 & 84.5 & 84.40 & 30 & 13.4 & 13.23 \\
\hline 15 & 80.0 & 79.85 & 31 & 11.8 & 11.69 \\
\hline 16 & 79.9 & 79.73 & & & \\
\hline
\end{tabular}

*Reference value for ${ }^{13} \mathrm{C}$ chemical shift for $\mathrm{MeOH}-\mathrm{d}_{4}$ at $\delta=49.15 \mathrm{ppm}$ (Cambridge Isotope Laboratories, NMR solvent data chart).

Table 2: Comparison of ${ }^{1} \mathrm{H}$ chemical shifts ${ }^{*}$ (listed in order of decreasing $\delta$ values), couplings and multiplicities of isolated ${ }^{1}(300 \mathrm{Mz})$ and synthetic maltepolide $\mathrm{C}(\mathbf{3})(\sim 2 \mathrm{mM}, 293 \mathrm{~K}, 700$ $\mathrm{MHz}$ ) in $\mathrm{MeOH}-\mathrm{d}_{4}$

\begin{tabular}{|l|l|l|}
\hline S.No & $\begin{array}{l}\text { Maltepolide C (isolated) ppm } \\
\text { (multiplicity and } J \text { in Hz) }\end{array}$ & $\begin{array}{l}\text { Maltepolide C (3) (synthetic) ppm (multiplicity } \\
\text { and } J \text { in Hz) }\end{array}$ \\
\hline 1 & $6.99(\mathrm{~d}, 10.9 \mathrm{~Hz}, 1 \mathrm{H})$ & $6.99(\mathrm{~d}, 11.5 \mathrm{~Hz}, 1 \mathrm{H})$ \\
\hline $2^{\#}$ & $6.60(\mathrm{dd}, 15.0,11.0 \mathrm{~Hz}, 1 \mathrm{H})$ & $6.60(\mathrm{ddd}, 14.8,11.5,1.5 \mathrm{~Hz}, 1 \mathrm{H})$ \\
\hline 3 & $6.38(\mathrm{dd}, 11.5,1.5 \mathrm{~Hz}, 1 \mathrm{H})$ & $6.36(\mathrm{dd}, 11.5,1.5 \mathrm{~Hz}, 1 \mathrm{H})$ \\
\hline 4 & $5.96(\mathrm{dd}, 15.5,6.8 \mathrm{~Hz}, 1 \mathrm{H})$ & $5.96(\mathrm{dd}, 15.6,6.5 \mathrm{~Hz}, 1 \mathrm{H})$ \\
\hline 5 & $5.85(\mathrm{~m}, 1 \mathrm{H})$ & $5.85(\mathrm{ddd}, 14.8,11.5,4.4 \mathrm{~Hz}, 1 \mathrm{H})$ \\
\hline 6 & $5.69(\mathrm{ddd}, 15.8,8.1,1.1 \mathrm{~Hz}, 1 \mathrm{H})$ & $5.71(\mathrm{ddd}, 15.6,8.1,1.2 \mathrm{~Hz}, 1 \mathrm{H})$ \\
\hline 7 & $5.45(\mathrm{dd}, 8.1,1.3 \mathrm{~Hz}, 1 \mathrm{H})$ & $5.44(\mathrm{dd}, 8.2,1.5 \mathrm{~Hz}, 1 \mathrm{H})$ \\
\hline 8 & $5.24(\mathrm{ddd}, 6.6,2.7,1.1 \mathrm{~Hz}, 1 \mathrm{H})$ & $5.23(\mathrm{ddd}, 6.5,2.5,1.2 \mathrm{~Hz}, 1 \mathrm{H})$ \\
\hline 9 & $4.56(\mathrm{dd}, 7.9,3.8 \mathrm{~Hz}, 1 \mathrm{H})$ & $4.56(\mathrm{dd}, 8.2,4.0 \mathrm{~Hz}, 1 \mathrm{H})$ \\
\hline 10 & $4.40(\mathrm{dd}, 10.6,5.2 \mathrm{~Hz}, 1 \mathrm{H})$ & $4.39(\mathrm{dd}, 11.0,4.8 \mathrm{~Hz}, 1 \mathrm{H})$ \\
\hline 11 & $4.27(\mathrm{~m}, 1 \mathrm{H})$ & $4.27(\mathrm{dq}, 11.5,6.5 \mathrm{~Hz}, 1 \mathrm{H})$ \\
\hline 12 & $4.07(\mathrm{~m}, 1 \mathrm{H})$ & $4.06(\mathrm{ddd}, 10.5,9.5,5.0 \mathrm{~Hz}, 1 \mathrm{H})$ \\
\hline 13 & $3.82(\mathrm{t}, 4.0 \mathrm{~Hz}, 1 \mathrm{H})$ & $3.82(\mathrm{t}, 4.0 \mathrm{~Hz}, 1 \mathrm{H})$ \\
\hline 14 & $3.78(\mathrm{dd}, 6.4,4.3 \mathrm{~Hz}, 1 \mathrm{H})$ & $3.77(\mathrm{qd}, 6.5,4.2 \mathrm{~Hz}, 1 \mathrm{H})$ \\
\hline 15 & $3.55(\mathrm{dd}, 8.1,4.3 \mathrm{~Hz}, 1 \mathrm{H})$ & $3.54(\mathrm{dd}, 8.1,4.2 \mathrm{~Hz}, 1 \mathrm{H})$ \\
\hline 16 & $3.35(\mathrm{~s}, 3 \mathrm{H})$ & $3.33(\mathrm{~s}, 3 \mathrm{H})$ \\
\hline 17 & $3.34(\mathrm{~s}, 3 \mathrm{H})$ & $3.29(\mathrm{~s}, 3 \mathrm{H})$ \\
\hline 18 & $2.45-2.60(\mathrm{~m}, 2 \mathrm{H})$ & $2.55(\mathrm{ddd}, 13.5,11.0,4.4 \mathrm{~Hz}, 1 \mathrm{H})$ \\
\hline & & $2.48(\mathrm{ddd}, 13.5,11.0,4.4 \mathrm{~Hz}, 1 \mathrm{H})$ \\
\hline 19 & $2.16(\mathrm{dd}, 13.0,5.1 \mathrm{~Hz}, 1 \mathrm{H})$ & $2.15(\mathrm{ddd}, 12.8,5.0,1.5 \mathrm{~Hz}, 1 \mathrm{H})$ \\
\hline 20 & $2.08(\mathrm{~d}, 1.5 \mathrm{~Hz}, 3 \mathrm{H})$ & $2.07(\mathrm{~d}, 1.5 \mathrm{~Hz}, 3 \mathrm{H})$ \\
\hline 21 & $1.95-2.00(\mathrm{~m}, 1 \mathrm{H})$ & $1.97(\mathrm{dqd}, 9.5,7.0,2.5 \mathrm{~Hz}, 1 \mathrm{H})$ \\
\hline 22 & $1.82(\mathrm{~s}, 3 \mathrm{H})$ & $1.81(\mathrm{~s}, 3 \mathrm{H})$ \\
\hline 23 & $1.80(\mathrm{~d}, 0.7 \mathrm{~Hz}, 3 \mathrm{H})$ & $1.79(\mathrm{~d}, 1.5 \mathrm{~Hz}, 3 \mathrm{H})$ \\
\hline 24 & $1.58(\mathrm{ddd}, 13.0,10.5,4.4 \mathrm{~Hz}, 1 \mathrm{H})$ & $1.58(\mathrm{ddd}, 12.8,10.5,4.0 \mathrm{~Hz}, 1 \mathrm{H})$ \\
\hline 25 & $1.11(\mathrm{~d}, 6.6 \mathrm{~Hz}, 3 \mathrm{H})$ & $1.12(\mathrm{~d}, 6.5 \mathrm{~Hz}, 3 \mathrm{H})$ \\
\hline 26 & $1.11(\mathrm{~d}, 6.6 \mathrm{~Hz}, 3 \mathrm{H})$ & $1.11(\mathrm{~d}, 6.5 \mathrm{~Hz}, 3 \mathrm{H})$ \\
\hline 27 & $0.89(\mathrm{~d}, 6.9 \mathrm{~Hz}, 3 \mathrm{H})$ & $0.88(\mathrm{~d}, 7.2 \mathrm{~Hz}, 3 \mathrm{H})$ \\
\hline
\end{tabular}

*Reference value for ${ }^{1} \mathrm{H}$ chemical shift for $\mathrm{MeOH}-\mathrm{d}_{4}$ at $\delta=3.31 \mathrm{ppm}$ (Cambridge Isotope laboratories, NMR solvent data chart).

\#Typographical error in the reported value of $6.54 \mathrm{ppm}$ (we have measured the chemical shift again, with a value of $6.60 \mathrm{ppm})$.

The published information on the chemical shifts and coupling constants of maltelopide A, maltelopide B and maltelopide $\mathrm{E}$ served as guideline in making the chemical shift 
assignments in the present case of maltepolide C (3). Due to the discrepancies observed in the chemical shifts it was felt appropriate to first have a closer look at the methoxy region of the NMR spectra. Thus one way to initiate the assignments was through the use of HSQC/HMBC spectrum and concentrating at the methoxy protons/carbon $(\sim 3.3 \mathrm{ppm} / \sim 57 \mathrm{ppm})$ region. In the

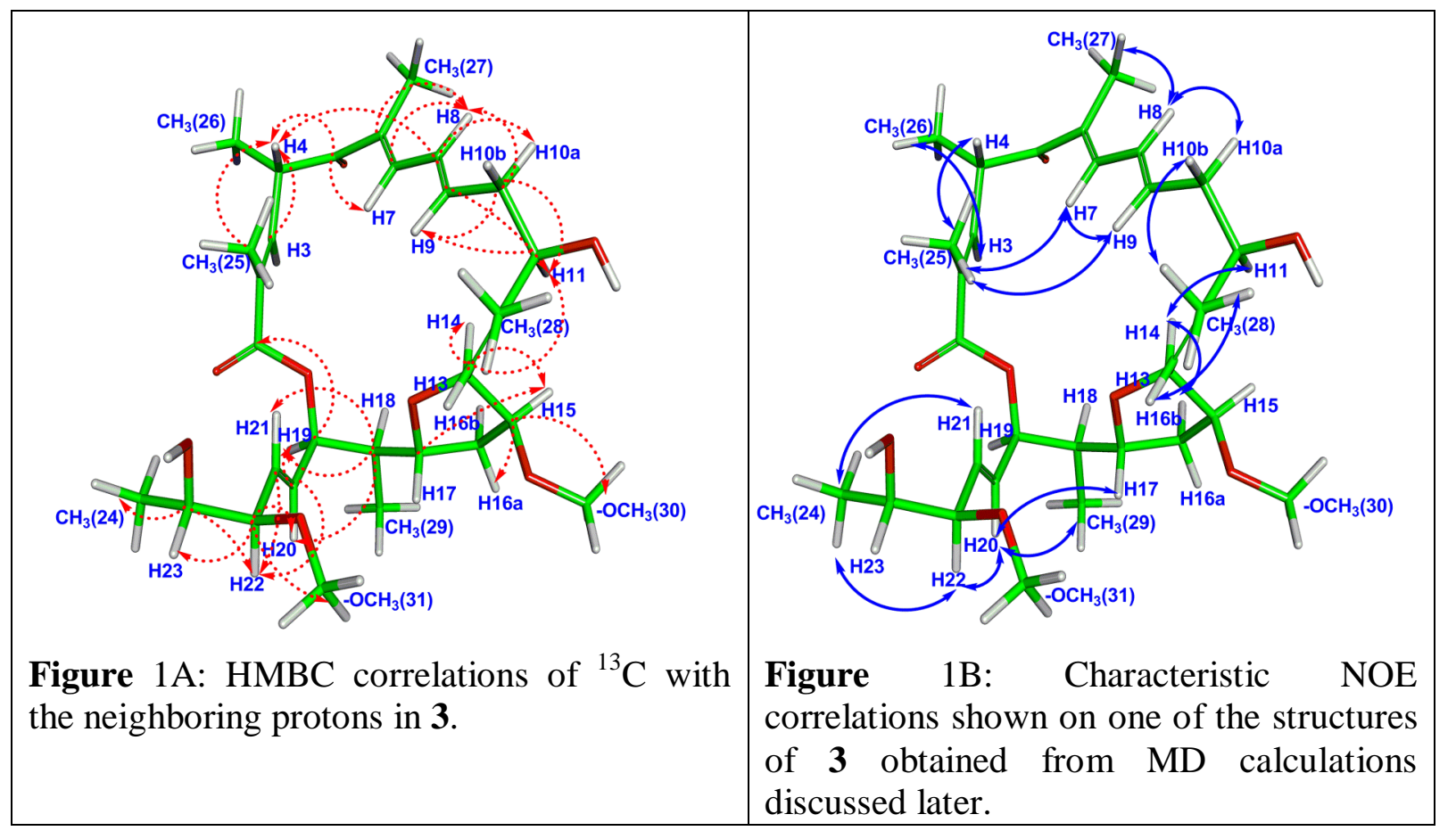

HMBC spectrum (Figure 1A gives the details of ${ }^{1} \mathrm{H}-{ }^{13} \mathrm{C}$ HMBC correlations in the spectrum) the two methoxy carbons correlate with $\mathrm{H} 22$ and $\mathrm{H} 15$ at 3.54 and 3.82 ppm respectively. Among these protons only one, $\mathrm{H} 22$ displays correlation with an olefinic proton (H21 at $5.71 \mathrm{ppm})$, thus enabling us to assign the chemical shifts $(\delta)$ of H22, H21 and H14 at 3.54, 5.71 and $4.56 \mathrm{ppm}$ respectively. Initiating the assignment process with methoxy protons (instead of the carbons as done above) and their correlations with C22 and C15 further validate these assignments. Thus the assignments of the methoxy proton/carbon were achieved $\left(-\mathrm{OCH}_{3}(30)\right.$ at 3.29/57.78 ppm and $-\mathrm{OCH}_{3}(31)$ at 3.33/57.06 ppm). After making these assignments, one can proceed to assign all the protons/carbons from in C13-C24 fragment, including the methyls and the methoxy protons. $\mathrm{CH}_{3}(28)$ could be assigned with correlations with $\mathrm{C} 13(128.85 \mathrm{ppm})$ and $\mathrm{H} 14(4.56 \mathrm{ppm})$ at 1.79/16.90 ppm. Further, $\mathrm{CH}_{3}(28)$ correlations with $\mathrm{C} 12(137.66 \mathrm{ppm})$ and $\mathrm{C} 11(77.28 \mathrm{ppm})$ in the HMBC spectrum facilitate the assignments in the C6-C12 fragment including $\mathrm{CH}_{3}(27)$. For 
fragments $\mathrm{C} 1-\mathrm{C} 5, \mathrm{C} 5(202.70 \mathrm{ppm}) / \mathrm{H} 7(6.99 \mathrm{ppm})$ correlation was crucial, which along with several HMBC correlations, completes the ${ }^{1} \mathrm{H}$ and ${ }^{13} \mathrm{C}$ chemical shift assignments for 3 .

Having made the assignments of all the protons and carbons, the coupling constants were deduced mainly from the ${ }^{1} \mathrm{H}$ spectrum, which if necessary was facilitated by decoupling experiments. The coupling constants ${ }^{3} J_{\mathrm{H} 8 / \mathrm{H} 9}=14.8 \mathrm{~Hz}$ and ${ }^{3} J_{\mathrm{H} 20 / \mathrm{H} 21}=15.6 \mathrm{~Hz}$ confirm the transdouble bonds at C8-C9 and C20-C21 respectively. Values of ${ }^{3} J_{\mathrm{H} 8 / \mathrm{H} 9}=14.8 \mathrm{~Hz}$ and ${ }^{3} J_{\mathrm{H} 3 / \mathrm{H} 4}=11.5$

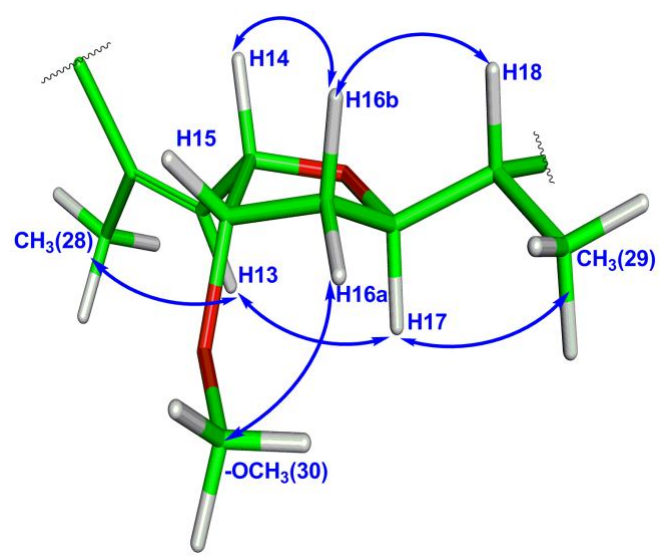

Figure 2: The envelop conformation of the tetrahydrofuran moiety along with the NOE correlations supporting the structure.

$\mathrm{Hz}$ and the NOE correlations $\mathrm{H} 3 / \mathrm{CH}_{3}(26)$ and $\mathrm{H} 4 / \mathrm{CH}_{3}(25)$ (Figure 1B shows the correlations obtained from NOESY experiments) support a C2-C3 trans-double bond. A strong NOE correlation, $\mathrm{H} 13 / \mathrm{CH}_{3}(28)$, justifies close proximity of these protons, consistent with C12-C13 cis-double bond. The five membered sugar ring takes an envelop conformation, which is confirmed through the coupling constants: ${ }^{3} J_{\mathrm{H} 14 / \mathrm{H} 15}=4.0,{ }^{3} J_{\mathrm{H} 15 / \mathrm{H} 16 \mathrm{~b}}=4.0,{ }^{3} J_{\mathrm{H} 15 / \mathrm{H} 16 \mathrm{a}}=1.5$, ${ }^{3} J_{\mathrm{H} 16 \mathrm{a} / \mathrm{H} 17}=5.0$ and ${ }^{3} J_{\mathrm{H} 16 \mathrm{~b} / \mathrm{H} 17}=10.5 \mathrm{~Hz}$ and the NOE correlations shown in Fig. 2. One very interesting observation was the fact that the 20 membered macrocycle appears quite rigid with most of the ${ }^{3} J$ involving the ring protons $<4.2 \mathrm{~Hz}$ or $>9.5 \mathrm{~Hz}$. In fact even the side chain C19C24, containing C21-C22 olefinic bond, with small value of ${ }^{3} J_{\mathrm{H} 22 / \mathrm{H} 23}(4.2 \mathrm{~Hz})$ along with several characteristic NOE correlations, appears to be fairly rigid. In view of above, and the need to draw more definite conclusions on the structure and configurations in the side chain, predominance of a single conformation was invoked. Thus ${ }^{3} J_{\mathrm{H} 19 / \mathrm{H} 20}=6.5 \mathrm{~Hz},{ }^{3} J_{\mathrm{H} 21 / \mathrm{H} 22}=8.1 \mathrm{~Hz}$ and ${ }^{3} J_{\mathrm{H} 22 / \mathrm{H} 23}=4.2 \mathrm{~Hz}$ were assumed to arise mainly from staggered conformations about the C-C single bonds, with H19-C19-C20-H20 $\left(\theta_{3}\right) \sim 60^{\circ}, \mathrm{H} 21-\mathrm{C} 21-\mathrm{C} 22-\mathrm{H} 22\left(\theta_{2}\right) \sim 180^{\circ}$ and $\mathrm{H} 22-\mathrm{C} 22-$ 
C23-H23 $\left(\theta_{1}\right) \sim 60^{\circ}$ respectively (Figure 3 for the definition of dihedral angles), which along with the observed NOE correlations $\mathrm{H} 20 / \mathrm{H} 22, \mathrm{H} 22 / \mathrm{CH}_{3}(24), \mathrm{H} 21 / \mathrm{CH}_{3}(24), \mathrm{H} 17 / \mathrm{H} 20$ and $\mathrm{H} 20 / \mathrm{CH}_{3}(29)$ emphatically support a $R$-configuration at $\mathrm{C} 22$.

In the discussion above, presence of a single predominant conformation with staggered geometries about the $\mathrm{C}-\mathrm{C}$ bonds in the side chains was invoked to arrive at the $R$-configuration at C22. However, it is evident that the Karplus equations provide multiple values of dihedral angles, which satisfy the experimentally observed couplings $(J)$. Thus having attributed an $R$ -

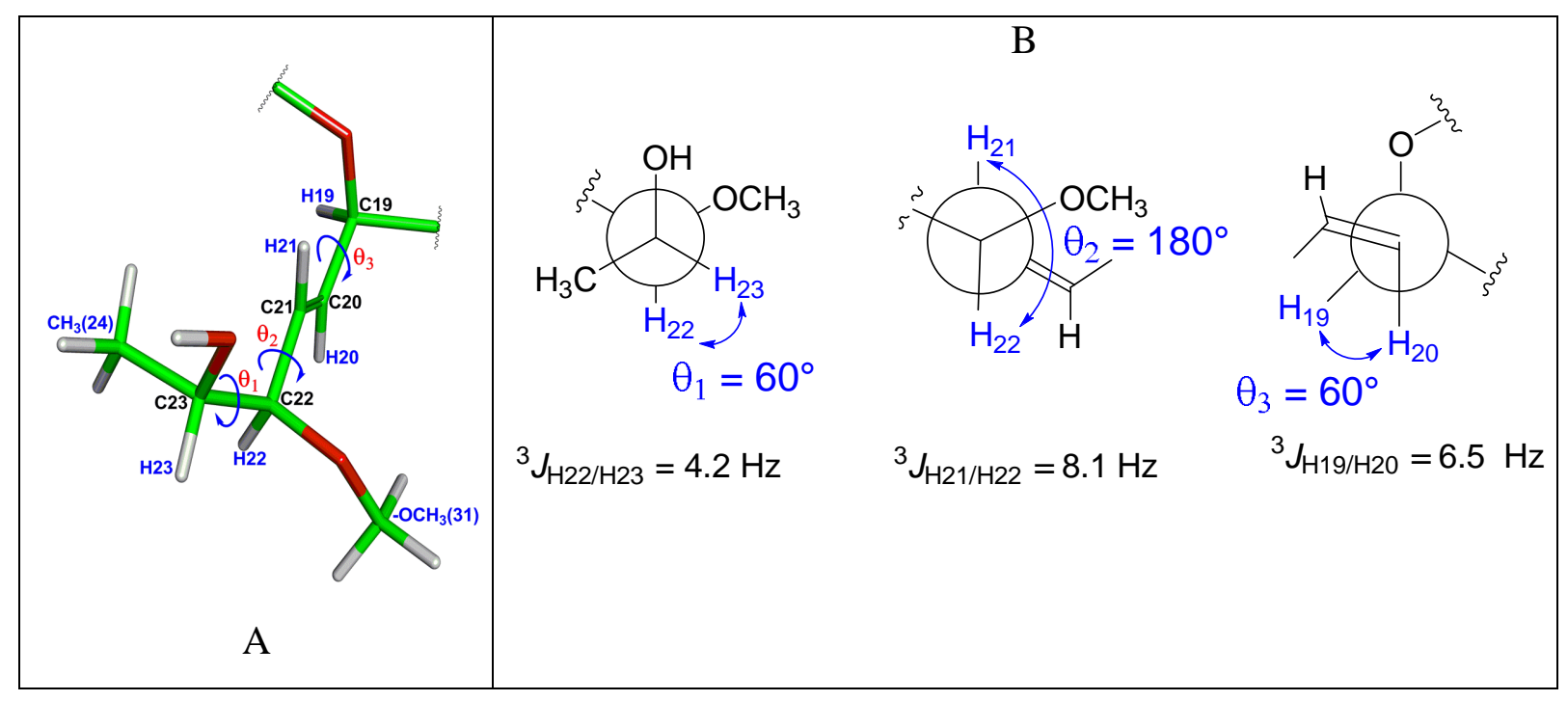

Figure 3: A) Definition of various dihedral angles in the side chain; B) Newman projections for single predominant conformers about C22-C23, C21-C22 and C19-C20 in the side chain (C19 C23 fragment) with the observed ${ }^{3} J$.

configuration at $\mathrm{C} 22$, it was imperative that we also explore and scan other conformations, which are consistent with the other options of the dihedral angles for these couplings and verify/rule out their presence through the NOE correlations. Avoiding a somewhat stringent condition of staggered conformations about $\mathrm{C}-\mathrm{C}$ bonds, and using the couplings to calculate the dihedral angles exactly using the Karplus equations (to about a degree), we looked at these combinations of the side chain conformation involving $\mathrm{C}-\mathrm{C}$ bonds in the $\mathrm{C} 19-\mathrm{C} 24$ carbon chain in more detail. $\mathrm{A}^{3} J_{\mathrm{H} 19 / \mathrm{H} 20}=6.5 \mathrm{~Hz}$ (if arising from a single conformation), would yield $\theta_{3}$ values of about $40^{\circ}$, $30^{\circ}, 145^{\circ}$ and $-130^{\circ}$. It was observed that only $\theta_{3} \sim 40^{\circ}$ is adequately supported by NOE correlations $\mathrm{H} 17 / \mathrm{H} 20$ and $\mathrm{H} 20 / \mathrm{CH}_{3}(29)$. On the other hand at the other end of the side chain, ${ }^{3} J_{\mathrm{H} 21 / \mathrm{H} 22}=8.1 \mathrm{~Hz}$ could arise from $\theta_{2} \sim 140^{\circ},-130^{\circ}$ and $\pm 10^{\circ}$ and ${ }^{3} J_{\mathrm{H} 22 / \mathrm{H} 23}=4.2 \mathrm{~Hz}$ could have 
$\theta_{1} \sim \pm 45^{\circ}$ and $\pm 125^{\circ}$. Thus we have tabulated (Table 3) all the structures that would satisfy ${ }^{3} J_{\mathrm{H} 19 / \mathrm{H} 20}=6.5 \mathrm{~Hz}$ and ${ }^{3} J_{\mathrm{H} 21 / \mathrm{H} 22}=8.1 \mathrm{~Hz}$, with $\theta_{1} \sim \pm 45^{\circ} \pm 125^{\circ}$ and $\theta_{2} \sim \pm 135^{\circ} / 0^{\circ}$ (we have approximated the value of $140 /-130^{\circ}$ as $\pm 135^{\circ}$ and value of $\sim \pm 10^{\circ}$ as $0^{\circ}$ ). Interestingly, only one set of values obtained by us is consistent with the derived structure having an $R$ configuration at $\mathrm{C} 22$. In addition, since the significant change in the chemical shifts were observed for $\mathrm{O}-\mathrm{Me}(31)$, attached to $\mathrm{C} 22$, we also explored a likely $S$-configuration at $\mathrm{C} 22$. For this configuration the observe couplings were found to be inconsistent with the NOEs (Table 4). The Table 5 lists the HMBC correlations and Table 6 lists the chemical shifts and couplings in 3.

Table 3: Possible dihedral angles $\left(\theta_{1}\right.$ and $\left.\theta_{2}\right)$ derived from the couplings, which are consistent $(\mathrm{Y}) /$ inconsistent $(\mathrm{N})$ with the observed NOE correlations for $R$-configuration at $\mathrm{C} 22$ in $\mathbf{3}$.

\begin{tabular}{|c|c|c|c|c|}
\hline \multicolumn{2}{|c|}{ Dihedral Angles } & \multicolumn{3}{c|}{ NOE correlations } \\
\hline$\theta_{1}\left({ }^{\circ}\right)$ & $\theta_{2}\left(^{\circ}\right)^{*}$ & $\mathrm{H} 20 / \mathrm{H} 22$ & $\mathrm{H} 21 / \mathrm{CH}_{3}(24)$ & $\mathrm{H} 22 / \mathrm{CH}_{3}(24)$ \\
\hline 45 & \pm 135 & $\mathrm{Y}$ & $\mathrm{Y}$ & $\mathrm{Y}$ \\
\hline-45 & \pm 135 & $\mathrm{Y}$ & $\mathrm{Y}$ & $\mathrm{N}$ \\
\hline 45 & 0 & $\mathrm{~N}$ & $\mathrm{Y}$ & $\mathrm{Y}$ \\
\hline-45 & 0 & $\mathrm{~N}$ & $\mathrm{~N}$ & $\mathrm{Y}$ \\
\hline 125 & \pm 135 & $\mathrm{Y}$ & $\mathrm{N}$ & $\mathrm{Y}$ \\
\hline-125 & \pm 135 & $\mathrm{Y}$ & $\mathrm{N}$ & $\mathrm{Y}$ \\
\hline 125 & 0 & $\mathrm{~N}$ & $\mathrm{~N}$ & $\mathrm{Y}$ \\
\hline-125 & 0 & $\mathrm{~N}$ & $\mathrm{~N}$ & $\mathrm{Y}$ \\
\hline
\end{tabular}

${ }^{*} \pm 135^{\circ}$ is an approximation for $140^{\circ} /-130^{\circ}$ and $0^{\circ}$ is an approximation for $\pm 10^{\circ}$.

Table 4: Possible dihedral angles $\left(\theta_{1}\right.$ and $\left.\theta_{2}\right)$ derived from the couplings, which are consistent $(\mathrm{Y})$ / inconsistent $(\mathrm{N})$ with the observed NOE correlations for $S$-configuration at C22 in 3 .

\begin{tabular}{|c|c|c|c|c|}
\hline \multicolumn{2}{|c|}{ Dihedral Angles } & \multicolumn{3}{c|}{ NOE correlations } \\
\hline$\theta_{1}\left(^{\circ}\right)$ & $\theta_{2}\left({ }^{\circ}\right)^{*}$ & $\mathrm{H} 20 / \mathrm{H} 22$ & $\mathrm{C} 24-\mathrm{Me} / \mathrm{H} 21$ & $\mathrm{C} 24-\mathrm{Me} / \mathrm{H} 22$ \\
\hline 45 & \pm 135 & $\mathrm{Y}$ & $\mathrm{N}$ & $\mathrm{Y}$ \\
\hline-45 & \pm 135 & $\mathrm{Y}$ & $\mathrm{Y}$ & $\mathrm{N}$ \\
\hline 45 & 0 & $\mathrm{~N}$ & $\mathrm{~N}$ & $\mathrm{Y}$ \\
\hline-45 & 0 & $\mathrm{~N}$ & $\mathrm{~N}$ & $\mathrm{~N}$ \\
\hline 125 & \pm 135 & $\mathrm{Y}$ & $\mathrm{N}$ & $\mathrm{Y}$ \\
\hline-125 & \pm 135 & $\mathrm{Y}$ & $\mathrm{N}$ & $\mathrm{Y}$ \\
\hline 125 & 0 & $\mathrm{~N}$ & $\mathrm{Y}$ & $\mathrm{Y}$ \\
\hline-125 & 0 & $\mathrm{~N}$ & $\mathrm{~N}$ & $\mathrm{~N}$ \\
\hline
\end{tabular}

${ }^{*} \pm 135^{\circ}$ is an approximation for $140^{\circ} / 130^{\circ}$ and $0^{\circ}$ is an approximation for $\pm 10^{\circ}$

\section{Stereochemistry at C15 :}


In the above discussions, we have concentrated on confirming the configuration at C22. However, the methoxy group at $\mathrm{C} 15$ also displays variation in the ${ }^{1} \mathrm{H}$ chemical shift. Thus we have also checked the configuration at $\mathrm{C} 15$. The coupling constants, ${ }^{3} J_{\mathrm{H} 14 / \mathrm{H} 15}=4.0,{ }^{3} J_{\mathrm{H} 15 / \mathrm{H} 16 \mathrm{~b}}=$ 4.0 and ${ }^{3} J_{\mathrm{H} 15 / \mathrm{H} 16 \mathrm{a}}=1.5 \mathrm{~Hz}$, in the tetrahydrofuran ring along with the NOE correlations, H16a/$\mathrm{OCH}_{3}(30), \mathrm{H} 14 / \mathrm{H} 16 b, \mathrm{H} 13 / \mathrm{H} 17, \mathrm{H} 16 \mathrm{~b} / \mathrm{H} 18, \mathrm{H} 17 / \mathrm{CH}_{3}(29)$ and $\mathrm{H} 13 / \mathrm{CH}_{3}(28)$ (Fig. 2), confirm a $S$-configuration at $\mathrm{C} 15$. This has been further elaborated in Table 5, where the values of the dihedral angles (H-C-C-H) in the tetrahydrofuran ring obtained from the Karplus equation and are compared with those obtained by MD calculations for one of the minimum energy structures (shown in Figure 2 in main text)

Table 5: Comparison of the dihedral angles in the tetrahydrofuran ring of $\mathbf{3}$ obtained from the ${ }^{3} J$ (Karplus equation) with that obtained from the MD calculations

\begin{tabular}{|c|c|c|c|}
\hline${ }^{3} J(\mathrm{~Hz})$ & Dihedral angles & $\begin{array}{c}\text { Dihedral angles }\left(^{\circ}\right) \\
(\mathrm{MD})\end{array}$ & $\begin{array}{c}\text { Dihedral angles }\left(^{\circ}\right. \\
(\text { Karplus equation })^{\mathrm{b}}\end{array}$ \\
\hline${ }^{3} J_{\mathrm{H} 13 / \mathrm{H} 14=8.2}$ & H13-C13-C14-H14 & 153 & 146 \\
\hline${ }^{3} J_{\mathrm{H} 14 / \mathrm{H} 15}=4.0$ & H14-C14-C15-H15 & 30 & 30 \\
\hline${ }^{3} J_{15-\mathrm{H} / \mathrm{H} 16 \mathrm{a}}=1.5$ & H15-C15-C16-H16a & 84 & 76 \\
\hline${ }^{3} J_{\mathrm{H} 15 / \mathrm{H} 16 \mathrm{~b}}=4.0$ & H15-C15-C16-H16b & -36 & -44 \\
\hline${ }^{3} J_{\mathrm{H} 16 \mathrm{a} / \mathrm{H} 17=5.0}=5.0$ & H16a-C16-C17-H17 & 43 & 38 \\
\hline${ }^{3} J_{\mathrm{H} 16 \mathrm{~b} / \mathrm{H} 17}=10.5$ & H16b-C16-C17-H17 & 163 & 161 \\
\hline
\end{tabular}

${ }^{a}$ from the minimum energy structure shown in Figure 2 from the MD calculations.

${ }^{\mathrm{b}}$ Calculated from Karplus equation (Haasnoot, C. A. G.; DeLeeuw, F. A. A. M.; Altona, C. Tetrahedron 1980, 36, 2783-2792).

Table 6: HMBC-correlations $\left({ }^{1} \mathrm{H}^{-13} \mathrm{C}\right)$ in 3

\begin{tabular}{|c|c|c|}
\hline Carbon $\delta(\mathrm{ppm})$ & Carbon & $\mathrm{HMBC}$ correlations with protons \\
\hline 168.66 & $\mathrm{C} 1$ & $\mathrm{H} 4, \mathrm{H} 19, \mathrm{CH}_{3}(25), \mathrm{H} 18$ \\
\hline 129.55 & $\mathrm{C} 2$ & $\mathrm{H} 4, \mathrm{CH}_{3}(25)$ \\
\hline 143.27 & $\mathrm{C} 3$ & $\mathrm{H} 4, \mathrm{CH}_{3}(25), \mathrm{CH}_{3}(26)$ \\
\hline 42.17 & $\mathrm{C} 4$ & $\mathrm{CH}_{3}(26)$ \\
\hline 202.70 & $\mathrm{C} 5$ & $\mathrm{H} 7, \mathrm{H} 4, \mathrm{CH}_{3}(25), \mathrm{CH}_{3}(26), \mathrm{CH}_{3}(27)$ \\
\hline 134.35 & $\mathrm{C} 6$ & $\mathrm{H} 8, \mathrm{CH}_{3}$ \\
\hline 142.14 & $\mathrm{C} 7$ & $\mathrm{CH}, \mathrm{CH}_{3}$ \\
\hline 129.59 & $\mathrm{C} 8$ & $\mathrm{H} 10 \mathrm{~b}, \mathrm{CH}, \mathrm{H} 11, \mathrm{H} 10 \mathrm{~b}, \mathrm{CH}_{3}(27)$ \\
\hline 140.90 & $\mathrm{C} 9$ & $\mathrm{H} 8, \mathrm{H} 9, \mathrm{H} 11$ \\
\hline 39.13 & $\mathrm{C} 10$ &
\end{tabular}




\begin{tabular}{|c|c|c|}
\hline 70.28 & C11 & $\mathrm{H} 9, \mathrm{H} 10 \mathrm{~b}, \mathrm{CH}_{3}(28)$ \\
\hline 137.66 & $\mathrm{C} 12$ & $\mathrm{H} 14, \mathrm{Hb}, \mathrm{CH}_{3}(28), \mathrm{H} 11$ \\
\hline 128.85 & $\mathrm{C} 13$ & $\mathrm{H} 14, \mathrm{H} 11, \mathrm{CH}_{3}(28)$ \\
\hline 79.73 & C14 & H14, H15, H16b \\
\hline 84.40 & $\mathrm{C} 15$ & $\mathrm{H} 14,-\mathrm{OCH} 3(30), \mathrm{H} 16 \mathrm{~b}, \mathrm{CH}_{3}(28)$ \\
\hline 38.55 & $\mathrm{C} 16$ & $\mathrm{H} 17, \mathrm{H} 14$ \\
\hline 79.85 & $\mathrm{C} 17$ & $\mathrm{H} 15, \mathrm{H} 16 \mathrm{a}, \mathrm{CH}_{3}(29)$ \\
\hline 42.76 & $\mathrm{C} 18$ & $\mathrm{H} 19, \mathrm{H} 16 \mathrm{a}, \mathrm{CH}_{3}(29)$ \\
\hline 79.46 & C19 & $\mathrm{H} 21, \mathrm{H} 20, \mathrm{H} 19, \mathrm{CH}_{3}(29)$ \\
\hline 132.04 & $\mathrm{C} 20$ & $\mathrm{H} 19, \mathrm{H} 23, \mathrm{H} 22$ \\
\hline 130.86 & $\mathrm{C} 21$ & $\mathrm{H} 19, \mathrm{H} 22$ \\
\hline 87.54 & $\mathrm{C} 22$ & $\mathrm{H} 21, \mathrm{H} 20, \mathrm{H} 23,-\mathrm{OCH} 3(31), \mathrm{CH}_{3}(24)$ \\
\hline 70.50 & $\mathrm{C} 23$ & $\mathrm{H} 22, \mathrm{CH}_{3}(24)$ \\
\hline 18.92 & $\mathrm{CH}_{3}(24)$ & $\mathrm{H} 22, \mathrm{H} 23$, \\
\hline 13.23 & $\mathrm{CH}_{3}(25)$ & $\mathrm{H} 3$ \\
\hline 15.39 & $\mathrm{CH}_{3}(26)$ & $\mathrm{H} 4, \mathrm{CH}_{3}(25)$ \\
\hline 11.69 & $\mathrm{CH}_{3}(27)$ & $\mathrm{H} 7$ \\
\hline 16.90 & $\mathrm{CH}_{3}(28)$ & H11 \\
\hline 14.20 & $\mathrm{CH}_{3}(29)$ & H19 \\
\hline 57.78 & $-\mathrm{OCH}_{3}(30)$ & H15 \\
\hline 57.06 & $-\mathrm{OCH}_{3}(31)$ & $\mathrm{H} 22$ \\
\hline
\end{tabular}

Table 7: ${ }^{1} \mathrm{H}$ and ${ }^{13} \mathrm{C}$ chemical shifts and coupling constants $\left(J_{\mathrm{H}-\mathrm{H}}\right)$ for $\mathbf{3}$

\begin{tabular}{|c|c|c|c|c|c|}
\hline Carbon & $\begin{array}{l}{ }^{13} \mathrm{C} \text { Chemical } \\
\text { shift }(\delta)(\mathrm{ppm})\end{array}$ & Proton & $\begin{array}{l}{ }^{1} \mathrm{H} \text { Chemical } \\
\text { shift }(\delta)(\mathrm{ppm})\end{array}$ & multiplicity & $J_{\mathrm{H}-\mathrm{H}}(\mathrm{Hz})$ \\
\hline $\mathrm{C} 1$ & 168.66 & & & & \\
\hline $\mathrm{C} 2$ & 129.55 & & & & \\
\hline $\mathrm{C} 3$ & 143.27 & $\mathrm{H} 3$ & 6.36 & $\mathrm{dd}$ & $\begin{array}{c}{ }^{3} J_{\mathrm{H} 3 / \mathrm{H} 4}=11.5 \\
{ }^{3} J_{\mathrm{H} 3 / \mathrm{CH} 3(25)}=1.5\end{array}$ \\
\hline $\mathrm{C} 4$ & 42.17 & $\mathrm{H} 4$ & 4.27 & $\mathrm{dq}$ & $\begin{array}{c}{ }^{3} J_{\mathrm{H} 3 / \mathrm{H} 4}=11.5 \\
{ }^{3} J_{\mathrm{H} 4 / \mathrm{CH} 3(26)}=6.5\end{array}$ \\
\hline $\mathrm{C} 5$ & 202.70 & & & & \\
\hline C6 & 134.35 & & & & \\
\hline $\mathrm{C} 7$ & 142.14 & H7 & 6.99 & $\mathrm{~d}$ & ${ }^{3} J_{\mathrm{H} 7 / \mathrm{H} 8}=11.5$ \\
\hline $\mathrm{C} 8$ & 129.59 & H8 & 6.60 & ddd & $\begin{array}{c}{ }^{3} J_{\mathrm{H} 8 / \mathrm{H} 9}=14.8 \\
{ }^{3} J_{\mathrm{H} 7 / \mathrm{H} 8}=11.5 \\
{ }^{3} J_{\mathrm{H} 8 / \mathrm{CH} 3(27)}=1.5\end{array}$ \\
\hline C9 & 140.90 & H9 & 5.85 & ddd & $\begin{array}{c}{ }^{3} J_{\mathrm{H} 8 / \mathrm{H} 9}=14.8 \\
{ }^{3} J_{\mathrm{H} 9 / \mathrm{H} 10 \mathrm{~b}}=11.5 \\
{ }^{3} J_{\mathrm{H} 9 / \mathrm{H} 10 \mathrm{a}}=4.4\end{array}$ \\
\hline $\mathrm{C} 10$ & 39.13 & H10a & 2.55 & ddd & ${ }^{2} J_{\mathrm{H} 10 \mathrm{a} / \mathrm{H} 10 \mathrm{~b}}=13.5$ \\
\hline
\end{tabular}




\begin{tabular}{|c|c|c|c|c|c|}
\hline & & & & & $\begin{aligned}{ }^{3} J_{\mathrm{H} 10 \mathrm{a} / \mathrm{H} 11} & =11.0 \\
{ }^{3} J_{\mathrm{H} / \mathrm{H} 10 \mathrm{a}} & =4.4\end{aligned}$ \\
\hline & & $\mathrm{H} 10 \mathrm{~b}$ & 2.48 & ddd & $\begin{array}{c}{ }^{2} J_{\mathrm{H} 10 \mathrm{a} / \mathrm{H} 10 \mathrm{~b}}=13.5 \\
{ }^{3} J_{\mathrm{H} / 10 \mathrm{~b}}=11.5 \\
{ }^{3} J_{\mathrm{H} 1 \mathrm{Ob} / \mathrm{H} 11}=4.8\end{array}$ \\
\hline C11 & 70.28 & H11 & 4.39 & $\mathrm{dd}$ & $\begin{array}{c}{ }^{3} J_{\mathrm{H} 1 \mathrm{a} / \mathrm{H} 11}=11.0 \\
{ }^{3} J_{\mathrm{H} 10 \mathrm{~b} / \mathrm{H} 11}=4.8\end{array}$ \\
\hline $\mathrm{C} 12$ & 137.66 & & & & \\
\hline $\mathrm{C} 13$ & 128.85 & H13 & 5.44 & dd & $\begin{array}{c}{ }^{3} J_{\mathrm{H} 13 / \mathrm{H} 14}=8.2 \\
{ }^{3} J_{\mathrm{H} 13 / \mathrm{CH} 3(28)}=1.5\end{array}$ \\
\hline C14 & 79.73 & H14 & 4.56 & $\overline{d d}$ & $\begin{aligned}{ }^{3} J_{\mathrm{H} 13 / \mathrm{H} 14} & =8.2 \\
{ }^{3} J_{\mathrm{H} 14 / \mathrm{H} 15} & =4.0\end{aligned}$ \\
\hline $\mathrm{C} 15$ & 84.40 & H15 & 3.82 & $\mathrm{t}$ & $\begin{aligned}{ }^{3} J_{\mathrm{H} 14 / \mathrm{H} 15} & =4.0 \\
{ }^{3} J_{\mathrm{H} 15 / \mathrm{H} 16 \mathrm{~b}} & =4.0\end{aligned}$ \\
\hline C16 & 38.55 & H16a & 2.15 & ddd & $\begin{aligned}{ }^{2} J_{\mathrm{H} 16 \mathrm{a} / \mathrm{H} 16 \mathrm{~b}} & =12.8 \\
{ }^{3} J_{\mathrm{H} 16 \mathrm{a} / \mathrm{H} 17} & =5.0 \\
{ }^{3} J_{\mathrm{H} 15 / \mathrm{H} 16 \mathrm{a}} & =1.5\end{aligned}$ \\
\hline & & H16b & 1.58 & ddd & $\begin{aligned}{ }^{2} J_{\mathrm{H} 16 \mathrm{a} / \mathrm{H} 16 \mathrm{~b}} & =12.8 \\
{ }^{3} J_{\mathrm{H} 16 \mathrm{~b} / \mathrm{H} 17} & =10.5 \\
{ }^{3} J_{\mathrm{H} 15 / \mathrm{H} 16 \mathrm{~b}} & =4.0\end{aligned}$ \\
\hline C17 & 79.85 & H17 & 4.06 & ddd & $\begin{aligned}{ }^{3} J_{\mathrm{H} 16 \mathrm{~b} / \mathrm{H} 17} & =10.5 \\
{ }^{3} J_{\mathrm{H} 17 / \mathrm{H} 18} & =9.5 \\
{ }^{3} J_{\mathrm{H} 16 \mathrm{a} / \mathrm{H} 17} & =5.0\end{aligned}$ \\
\hline $\mathrm{C} 18$ & 42.76 & H18 & 1.97 & dqd & $\begin{array}{c}{ }^{3} J_{\mathrm{H} 17 / \mathrm{H} 18}=9.5 \\
{ }^{3} J_{\mathrm{H} 18 / \mathrm{CH} 3(29)}=7.0 \\
{ }^{3} J_{\mathrm{H} 18 / \mathrm{H} 19}=2.5\end{array}$ \\
\hline C19 & 79.46 & H19 & 5.23 & ddd & $\begin{array}{l}{ }^{3} J_{\mathrm{H} 19 / \mathrm{H} 20}=6.5 \\
{ }^{3} J_{\mathrm{H} 18 / \mathrm{H} 19}=2.5 \\
{ }^{4} J_{\mathrm{H} 19 / \mathrm{H} 21}=1.2\end{array}$ \\
\hline $\mathrm{C} 20$ & 132.04 & $\mathrm{H} 20$ & 5.96 & $\mathrm{dd}$ & $\begin{array}{c}{ }^{3} J_{20-\mathrm{H} / 21-\mathrm{H}}=15.6 \\
{ }^{3} J_{19-\mathrm{H} / 20-\mathrm{H}}=6.5\end{array}$ \\
\hline $\mathrm{C} 21$ & 130.86 & $\mathrm{H} 21$ & 5.71 & ddd & $\begin{aligned}{ }^{3} J_{20-\mathrm{H} / \mathrm{H} 21} & =15.6 \\
{ }^{3} J_{\mathrm{H} 21 / \mathrm{H} 22} & =8.1 \\
{ }^{4} J_{\mathrm{H} 19 / \mathrm{H} 21} & =1.2\end{aligned}$ \\
\hline $\mathrm{C} 22$ & 87.54 & $\mathrm{H} 22$ & 3.54 & $\mathrm{dd}$ & $\begin{aligned}{ }^{3} J_{\mathrm{H} 21 / \mathrm{H} 22} & =8.1 \\
{ }^{3} J_{\mathrm{H} 22 / \mathrm{H} 23} & =4.2\end{aligned}$ \\
\hline $\mathrm{C} 23$ & 70.50 & $\mathrm{H} 23$ & 3.77 & $\overline{q d}$ & $\begin{array}{c}{ }^{3} J_{\mathrm{H} 23 / \mathrm{CH} 3(24)}=6.5 \\
{ }^{3} J_{\mathrm{H} 22 / \mathrm{H} 23}=4.2\end{array}$ \\
\hline $\mathrm{CH}_{3}(24)$ & 18.92 & $\mathrm{CH}_{3}(24)$ & 1.12 & $\mathrm{~d}$ & ${ }^{3} J_{\mathrm{H} 23 / \mathrm{CH} 3(24)}=6.5$ \\
\hline $\mathrm{CH}_{3}(25)$ & 13.23 & $\mathrm{CH}_{3}(25)$ & 2.07 & $\mathrm{~d}$ & ${ }^{3} J_{\mathrm{H} 3 / \mathrm{CH}(25)}=1.5$ \\
\hline $\mathrm{CH}_{3}(26)$ & 15.39 & $\mathrm{CH}_{3}(26)$ & 1.11 & $\mathrm{~d}$ & ${ }^{3} J_{\mathrm{H} 4 / \mathrm{CH} 3(26)}=6.5$ \\
\hline $\mathrm{CH}_{3}(27)$ & 11.69 & $\mathrm{CH}_{3}(27)$ & 1.81 & $\mathrm{~s}$ & --------- \\
\hline $\mathrm{CH}_{3}(28)$ & 16.90 & $\mathrm{CH}_{3}(28)$ & 1.79 & $\mathrm{~d}$ & ${ }^{3} J_{\mathrm{H}_{13 / \mathrm{CH} 3(28)}}=1.5$ \\
\hline $\mathrm{CH}_{3}(29)$ & 14.20 & $\mathrm{CH}_{3}(29)$ & 0.88 & $\mathrm{~d}$ & ${ }^{3} J_{\mathrm{H} 18 / \mathrm{CH} 3(29)}=7.2$ \\
\hline$-\mathrm{OCH}_{3}(30)$ & 57.78 & $-\mathrm{OCH}_{3}(30)$ & 3.29 & $\mathrm{~s}$ & --------- \\
\hline$-\mathrm{OCH}_{3}(31)$ & 57.06 & $-\mathrm{OCH}_{3}(31)$ & 3.33 & $\mathrm{~s}$ & ---------- - \\
\hline
\end{tabular}

\section{Variable temperature and concentration ${ }^{1} \mathrm{H}$ and ${ }^{13} \mathrm{C}$ NMR studies of compound 3:}

In addition we have also studied the variations of the ${ }^{1} \mathrm{H}$ and the ${ }^{13} \mathrm{C}$ chemical shift as a function of temperature and concentration to rule out the influences arising from molecular association and other interactions. The results are tabulated in Tables 8 and 9. 
Table 8: ${ }^{1} \mathrm{H}$ and ${ }^{13} \mathrm{C}$ Chemical shifts with temperature of synthetic maltepolide $\mathrm{C}$ (3) in $\mathrm{MeOH}-$ $\mathrm{d}_{4}(4 \mathrm{mM})$

\begin{tabular}{|c|c|c|c|c|}
\hline Temperature & \multicolumn{2}{|c|}{${ }^{1} \mathrm{H} \delta p m^{*}$} & \multicolumn{2}{c|}{${ }^{13} \mathrm{C} \delta \mathrm{ppm}$} \\
\hline & $\mathrm{OMe}(30)$ & $\mathrm{OMe}(31)$ & $\mathrm{OMe}(30)$ & $\mathrm{OMe}(31)$ \\
\hline $10^{\circ} \mathrm{C}$ & 3.296 & 3.338 & 57.82 & 57.15 \\
\hline $20^{\circ} \mathrm{C}$ & 3.299 & 3.340 & & 57.18 \\
\hline $25^{\circ} \mathrm{C}$ & 3.299 & 3.340 & 57.88 & \\
\hline $30^{\circ} \mathrm{C}$ & 3.301 & 3.342 & & 57.21 \\
\hline $40^{\circ} \mathrm{C}$ & 3.302 & 3.343 & 57.94 & \\
\hline $50^{\circ} \mathrm{C}$ & 3.303 & 3.343 & & \\
\hline
\end{tabular}

*for comparison ${ }^{\mathrm{I}} \mathrm{H}$ chemical shift have been reported up to third decimal.

Table 9: ${ }^{1} \mathrm{H}$ and ${ }^{13} \mathrm{C}$ Chemical shifts with concentration of synthetic maltepolide $\mathrm{C}$ (3) in $\mathrm{MeOH}$ $\mathrm{d}_{4}\left(25^{\circ} \mathrm{C}\right)$

\begin{tabular}{|c|c|c|c|c|}
\hline concentration & \multicolumn{2}{|c|}{${ }^{1} \mathrm{H} \delta \mathrm{ppm}^{*}$} & \multicolumn{2}{c|}{${ }^{13} \mathrm{C} \delta \mathrm{ppm}$} \\
\hline & $\mathrm{OMe}(30)$ & $\mathrm{OMe}(31)$ & $\mathrm{OMe}(30)$ & $\mathrm{OMe}(31)$ \\
\hline $2 \mathrm{mM}$ & 3.294 & 3.335 & 57.78 & 57.06 \\
\hline $4 \mathrm{mM}$ & 3.299 & 3.340 & 57.88 & 57.18 \\
\hline
\end{tabular}

* for comparison ${ }^{1} \mathrm{H}$ chemical shift have been reported up to third decimal.

\section{Molecular dynamics study:}

Molecular dynamics simulations (MD) is one of the principal tools in the theoretical study of natural products and biological molecules. The molecular modeling calculations and energy minimization were carried out using Builder module in Insight-II (97.0)//Discover program on a Silicon Graphics Workstation. The CVFF (Consistent Valence Force Field) force field with default parameters was employed for all the calculations using a distance dependent dielectric constant with $\varepsilon=32.7$ (dielectric constant of $\mathrm{CD}_{3} \mathrm{OD}$ ), which allows the inclusion of the solvent implicitly. A large number of restraints were used qualitatively in the restraint MD calculations. Thus strong intensity NOE correlations (s) were used to restrain the inter-atomic distance between 1.8- 2.5 ̊́, medium intensity (m) cross peak intensities between 1.8-3.5 ̊́ and weak intensity $(\mathrm{w})$ cross peak restrained distance between 1.8-4.5 ̊́. The inter-atomic distances used for restrained MD calculation are given in Table 7. These constraints with a force constant of $15 \mathrm{kcal} \mathrm{mol}^{-1} \AA^{-2}$ were applied in the form of a flat-bottom potential. These restraints were used throughout the MD simulations as well as the minimization. For the initiation of the dynamics the molecular model was built using the values of the dihedral angles deduced from the coupling constants as well as the NOEs. As a first step, the steric contacts were removed by a 
mild minimization with the constraints. Subsequently energy minimizations were performed using steepest descent methods, followed by conjugate gradient methods for a maximum of 1000 iterations each or RMS deviation of $0.001 \mathrm{kcal} \mathrm{mol}^{-1}$, whichever was achieved earlier. The energy-minimized structures were usually subjected to constrained MD simulations for duration of $2 \mathrm{~ns}$ at $300 \mathrm{~K}$ with the time step of $1 \mathrm{fs}$ and with NVT ensemble. The 100 structures generated were energy minimized with the above protocol. Stereoview of the superposition of 10 best structures with the heavy atom and the backbone root-mean square deviation (RMSD) of $0.14 \pm 0.07 \AA ̊$ and $0.16 \pm 0.13 \AA$ respectively is shown in Fig. 3 . The average values of $\theta_{2}=151 \pm 1^{\circ}$ and $\theta_{3}=51 \pm 1^{\circ}$ agree with those for metapolide-F $\left(\theta_{2}=-174^{\circ}\right.$ and $\left.\theta_{3} \sim 56^{\circ}\right)$. On the other hand $\theta_{1}=61 \pm 1^{\circ}$ differs from the X-ray value of $-68^{\circ}$, possibly because of a heavy OTBS substituent, instead of $\mathrm{OH}$ in 3.

Table 10: Distance constraints used in MD calculations* for 3

\begin{tabular}{|c|c|c|c|c|c|c|c|}
\hline \multicolumn{7}{|c|}{ NOE cross peak intensities } \\
\hline S1.No & From & To & Intensity & Sl. No & From & To & Intensity \\
\hline 1. & $\mathrm{H} 3$ & $\mathrm{CH}_{3}(26)$ & $\mathrm{m}$ & 9. & $\mathrm{H} 11$ & $\mathrm{H} 14$ & $\mathrm{~m}$ \\
\hline 2. & $\mathrm{H} 4$ & $\mathrm{CH}_{3}(25)$ & $\mathrm{s}$ & 10. & $\mathrm{H} 13$ & $\mathrm{CH}_{3}(28)$ & $\mathrm{s}$ \\
\hline 3. & $\mathrm{H} 7$ & $\mathrm{CH}_{3}(25)$ & $\mathrm{m}$ & 11. & $\mathrm{H} 14$ & $\mathrm{H} 16 \mathrm{~b}$ & $\mathrm{~s}$ \\
\hline 4. & $\mathrm{H} 9$ & $\mathrm{CH}_{3}(25)$ & $\mathrm{w}$ & 12. & $\mathrm{H} 17$ & $\mathrm{H} 20$ & $\mathrm{~s}$ \\
\hline 5. & $\mathrm{H} 7$ & $\mathrm{H} 9$ & $\mathrm{~s}$ & 13. & $\mathrm{H} 20$ & $\mathrm{CH}_{3}(29)$ & $\mathrm{m}$ \\
\hline 6. & $\mathrm{H} 8$ & $\mathrm{H} 10 \mathrm{a}$ & $\mathrm{s}$ & 14. & $\mathrm{H} 21$ & $\mathrm{CH}_{3}(24)$ & $\mathrm{m}$ \\
\hline 7. & $\mathrm{H} 8$ & $\mathrm{CH}_{3}(27)$ & $\mathrm{s}$ & 15. & $\mathrm{H} 22$ & $\mathrm{CH}_{3}(24)$ & $\mathrm{m}$ \\
\hline 8. & $\mathrm{H} 10 \mathrm{~b}$ & $\mathrm{CH}_{3}(28)$ & $\mathrm{w}$ & 16. & $\mathrm{H} 20$ & $\mathrm{H} 22$ & $\mathrm{~s}$ \\
\hline
\end{tabular}

* Strong cross peak intensities (s) correspond to inter-atomic distances between 1.8- $2.5 \AA$, medium cross peak intensities (m) corresponds to inter-atomic distances between 1.8- $3.5 \AA$ and weak cross peak intensities $(\mathrm{w})$ corresponds to inter-atomic distances between 1.8-4.5 $\AA$.
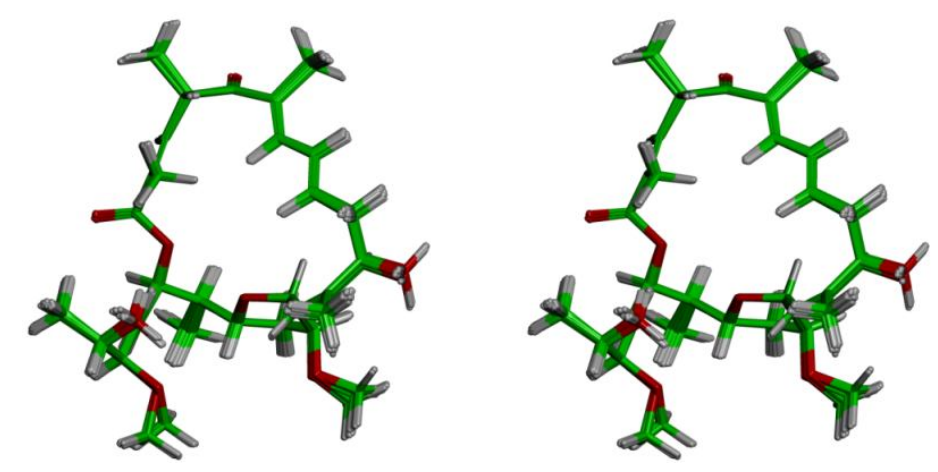

Figure 4: Stereoview of the superimposition of ten best structures for $\mathbf{3}$ from MD calculations. 


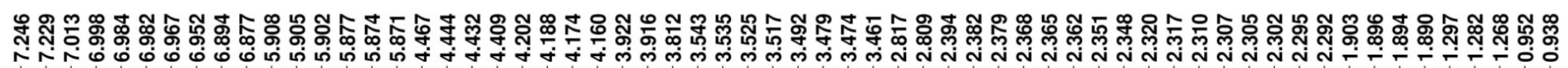

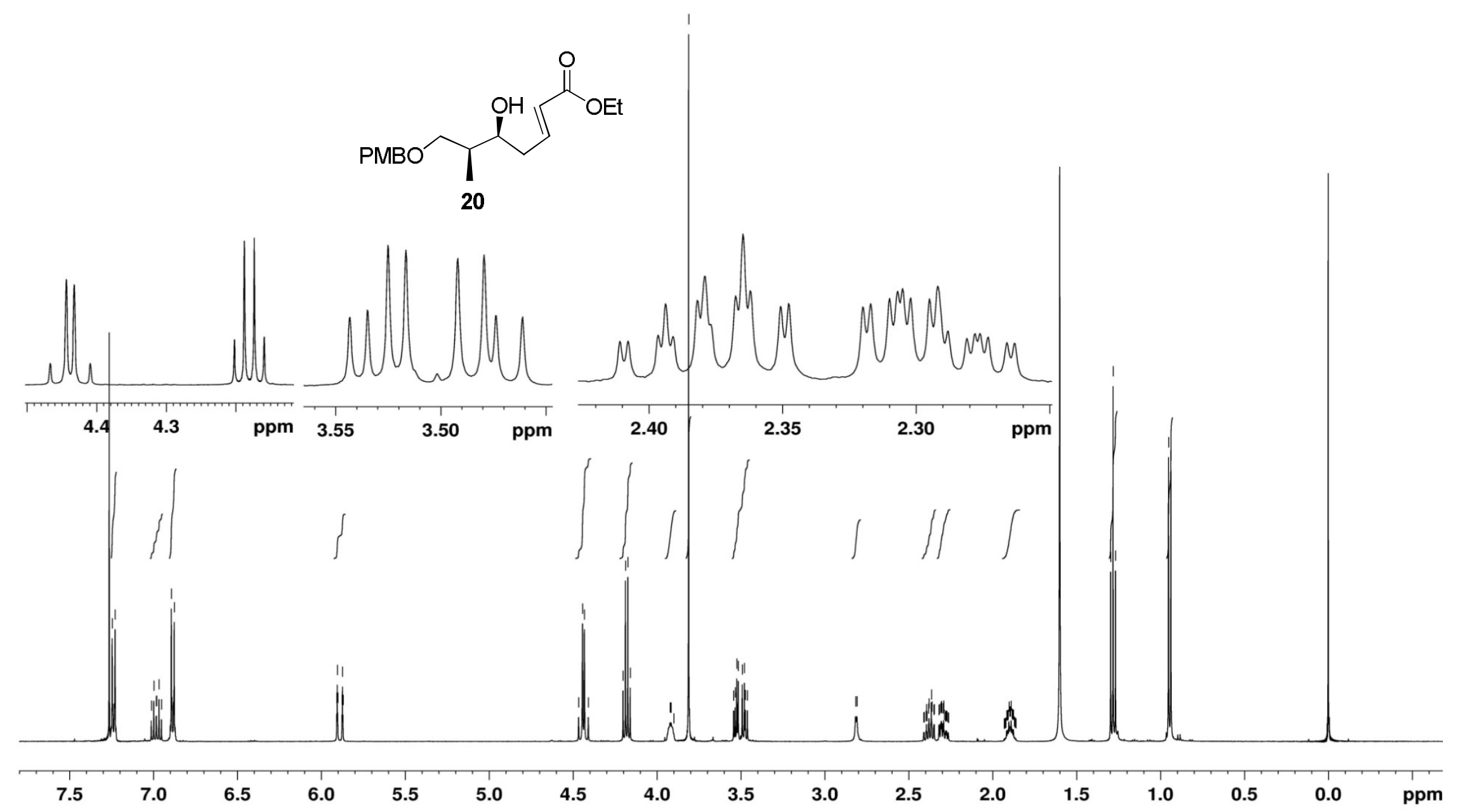

${ }^{1} \mathrm{H}$ NMR spectrum of $20\left(\mathrm{CDCl}_{3}, 500 \mathrm{MHz}\right)$ 

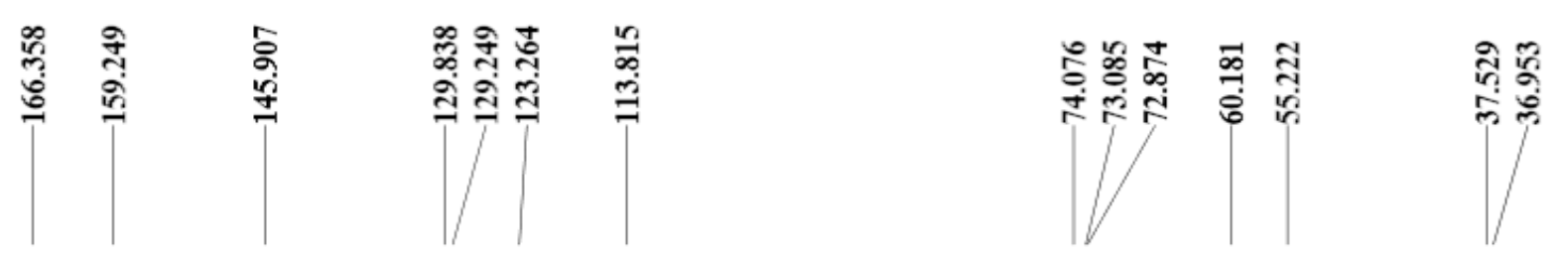

สี
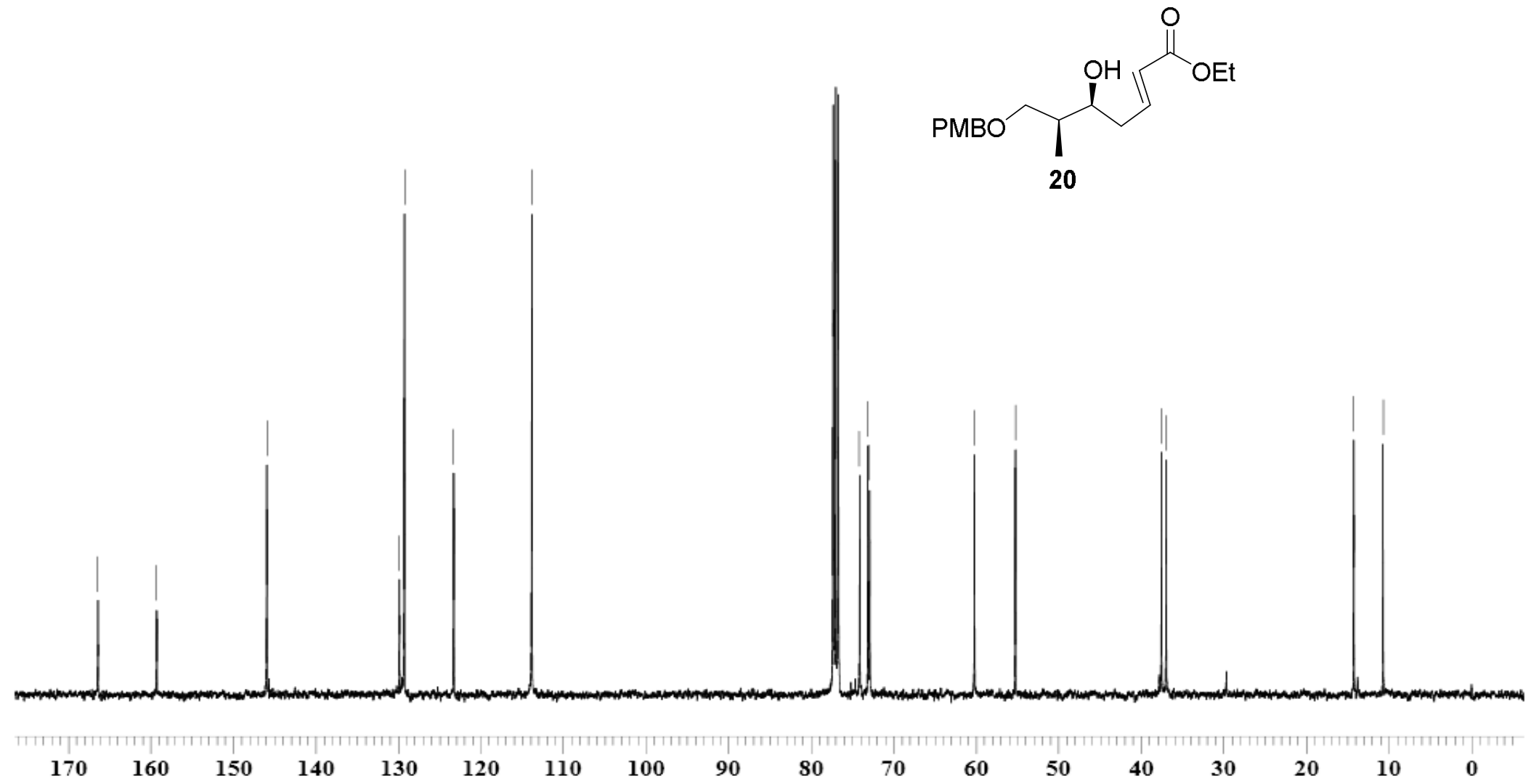

${ }^{13} \mathrm{C}$ NMR spectrum of $20\left(\mathrm{CDCl}_{3}, 100 \mathrm{MHz}\right)$ 


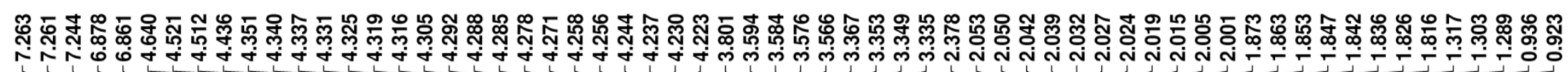

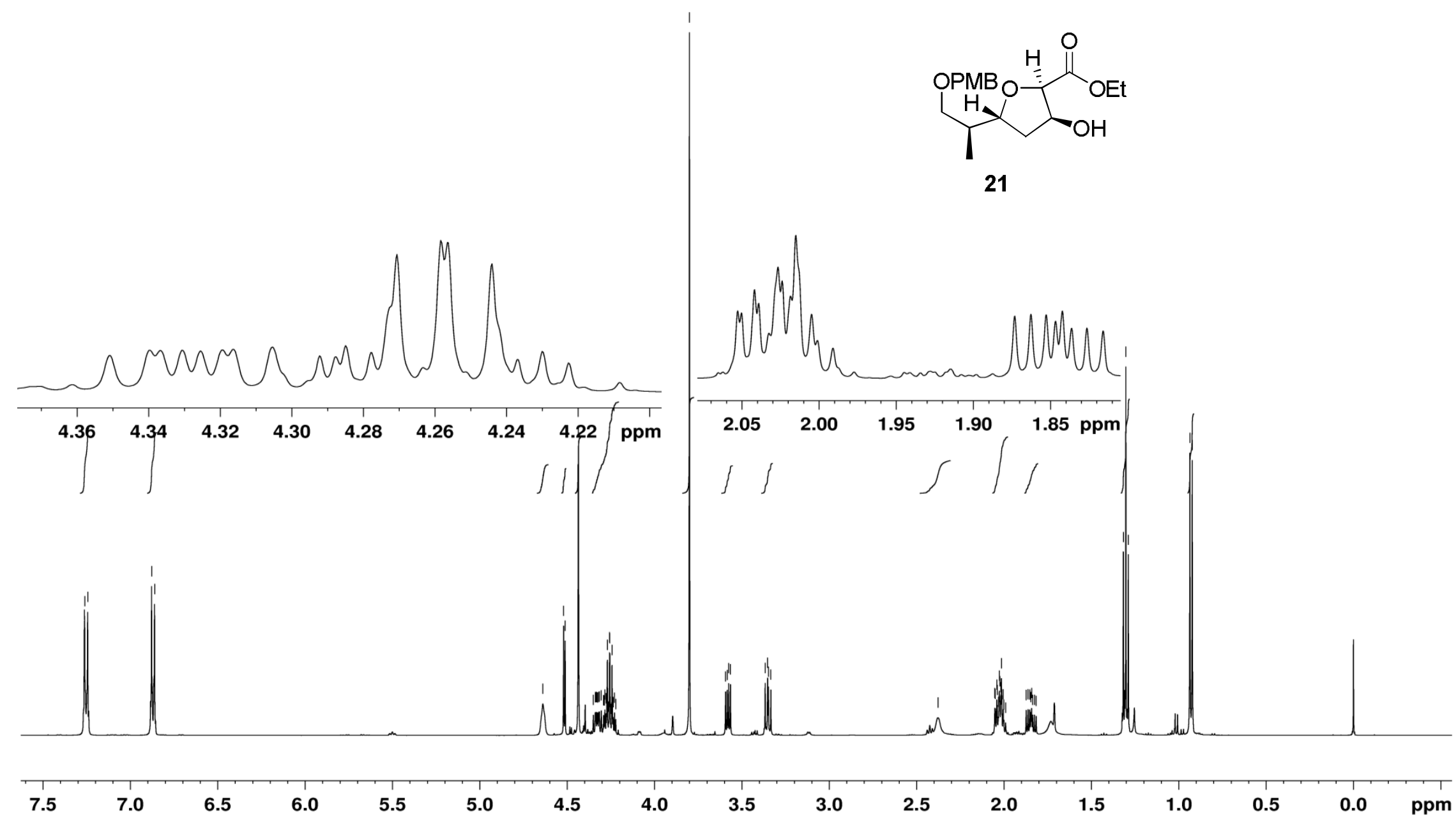

${ }^{1} \mathrm{H}$ NMR spectrum of $21\left(\mathrm{CDCl}_{3}, 500 \mathrm{MHz}\right)$ 


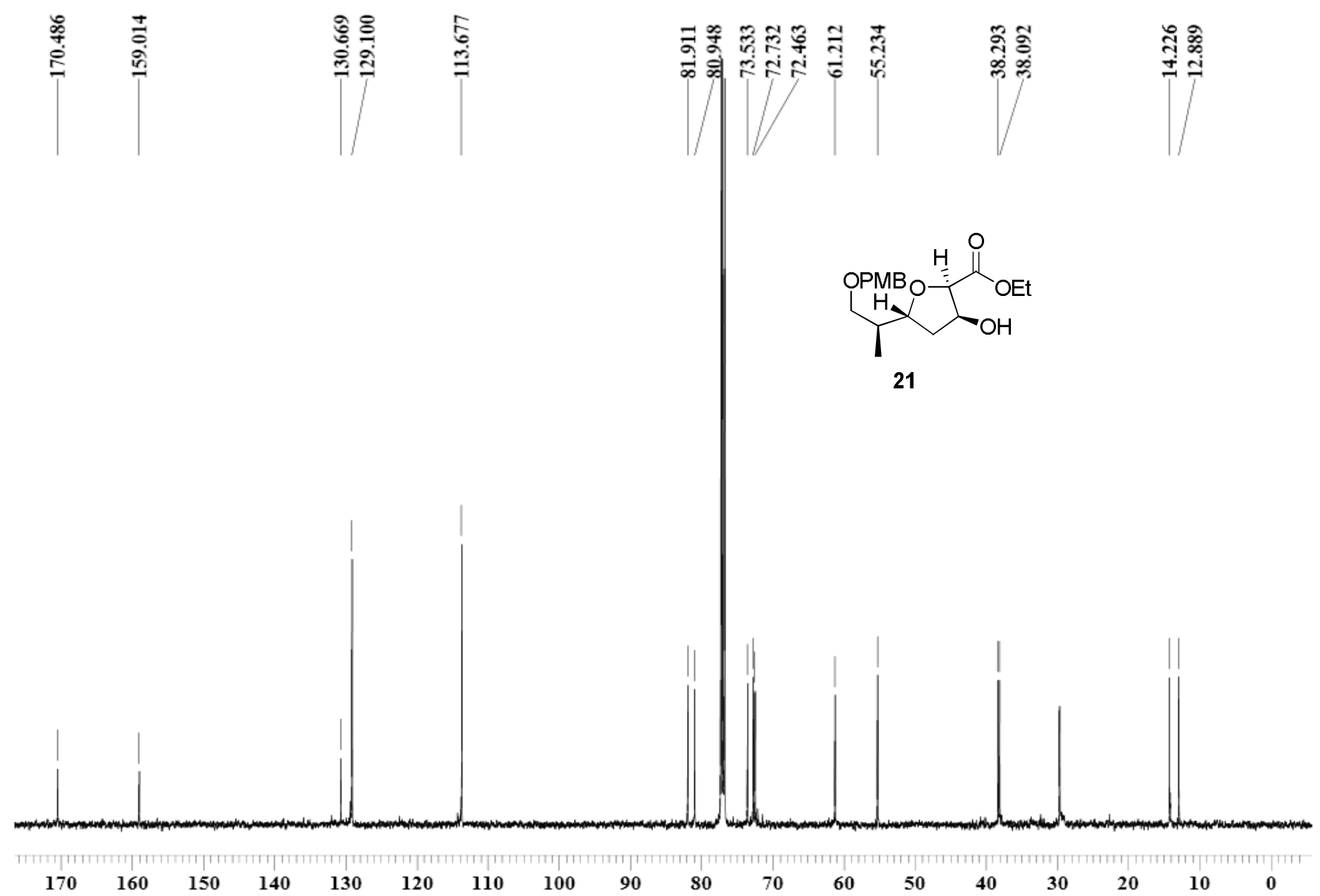

${ }^{13} \mathrm{C}$ NMR spectrum of $21\left(\mathrm{CDCl}_{3}, 500 \mathrm{MHz}\right)$ 


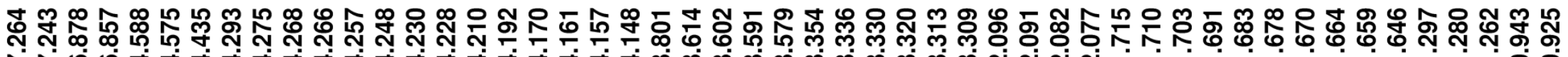
N N

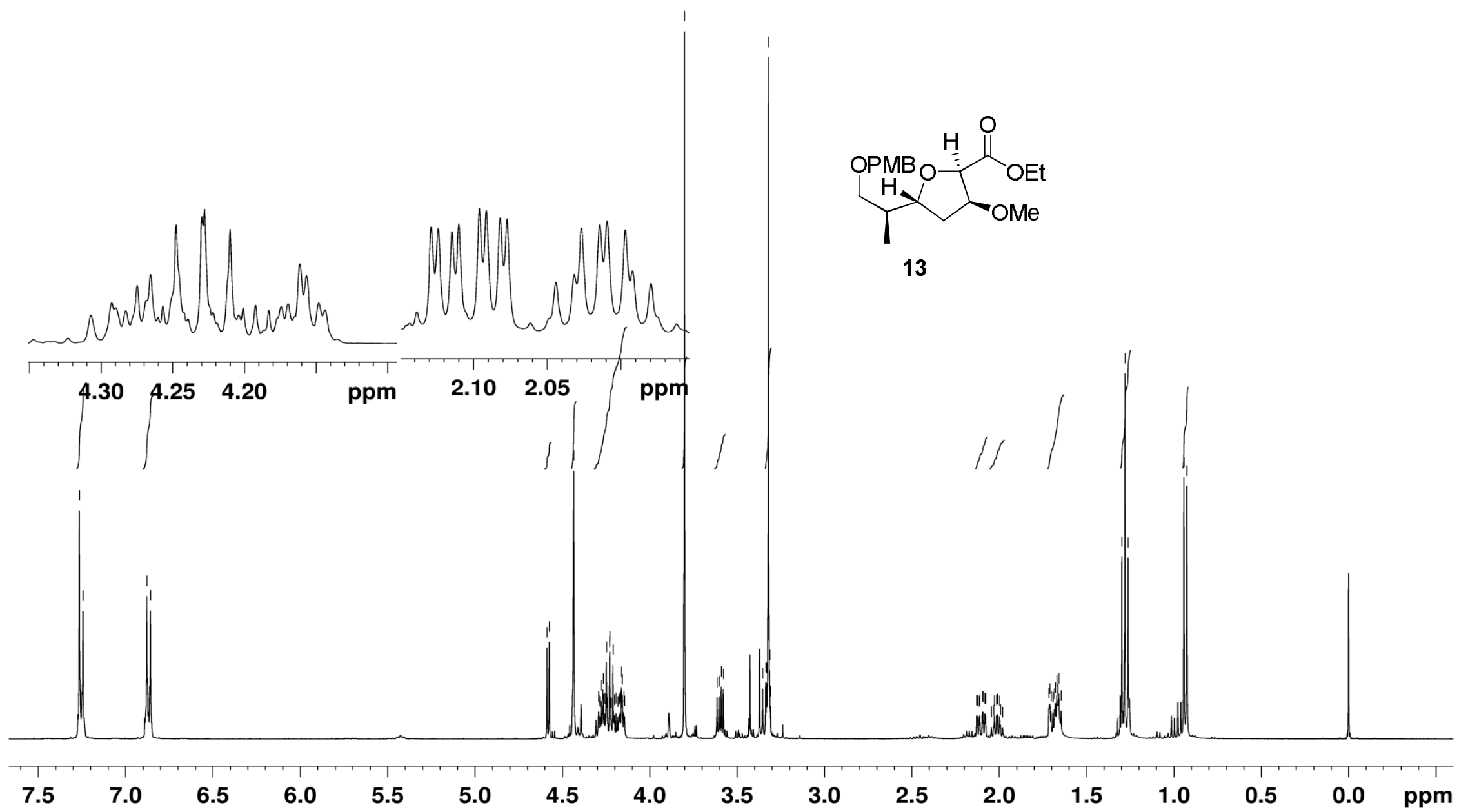

${ }^{1} \mathrm{H}$ NMR spectrum of $13\left(\mathrm{CDCl}_{3}, 400 \mathrm{MHz}\right)$ 

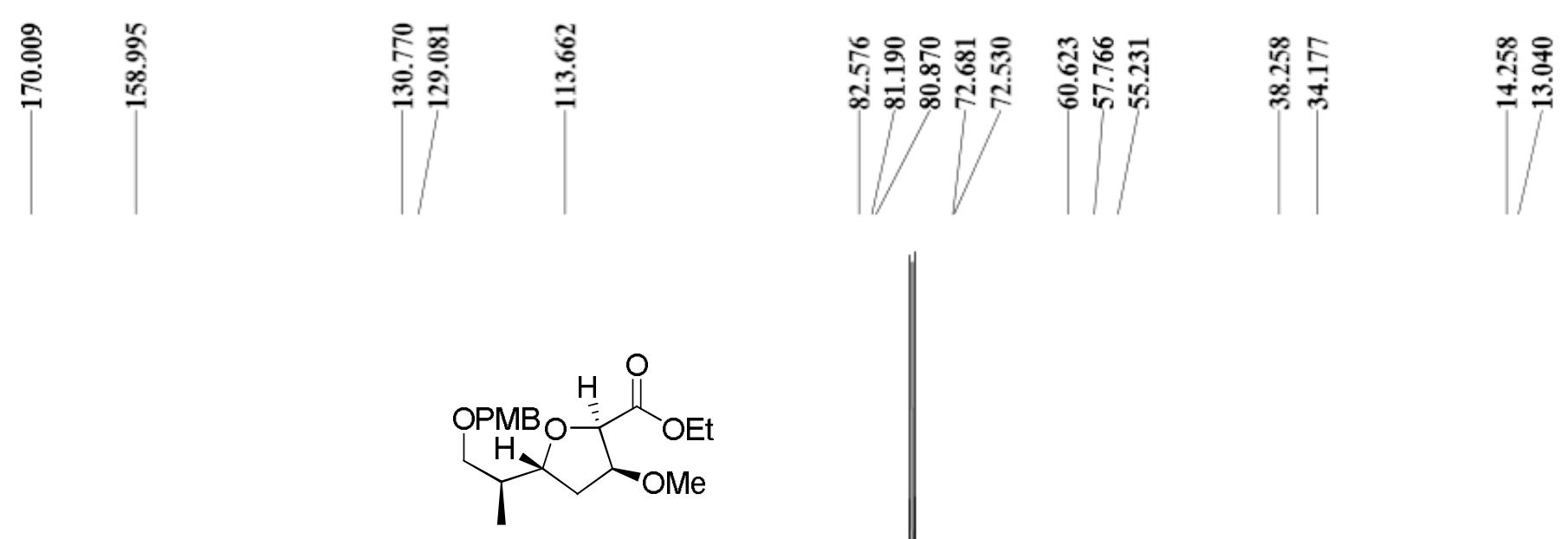

13

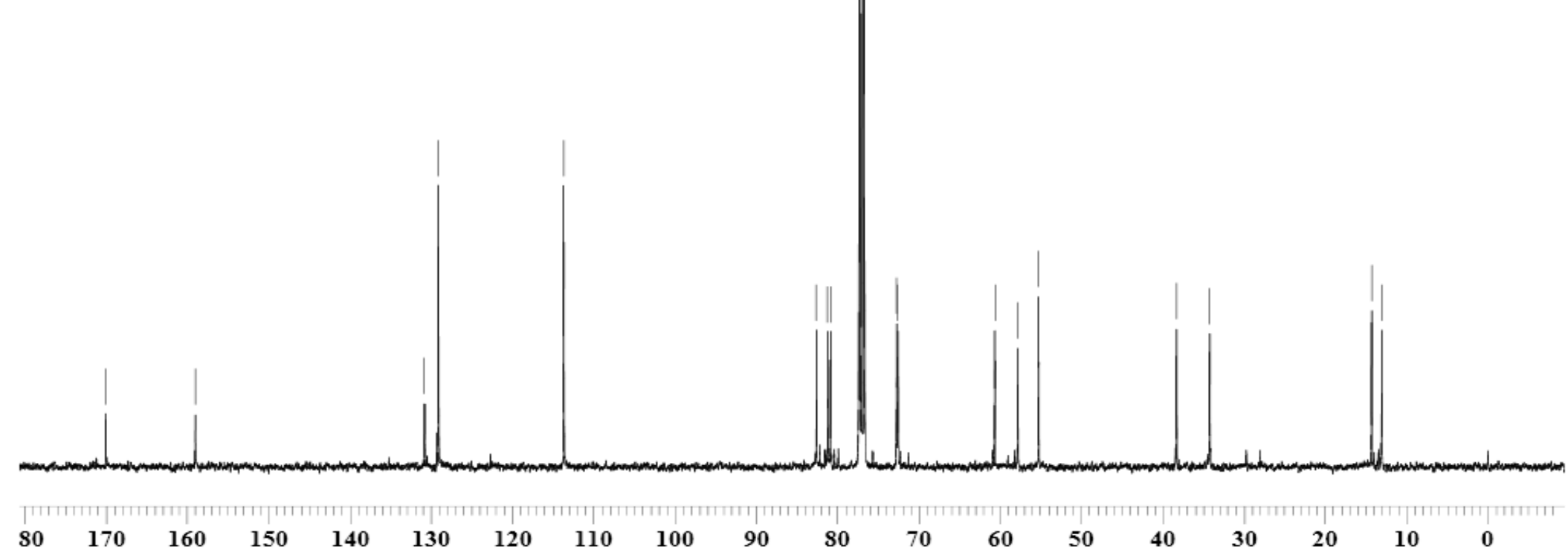

${ }^{13} \mathrm{C}$ NMR spectrum of $13\left(\mathrm{CDCl}_{3}, 100 \mathrm{MHz}\right)$ 


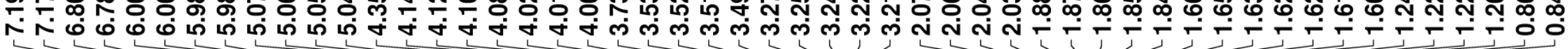

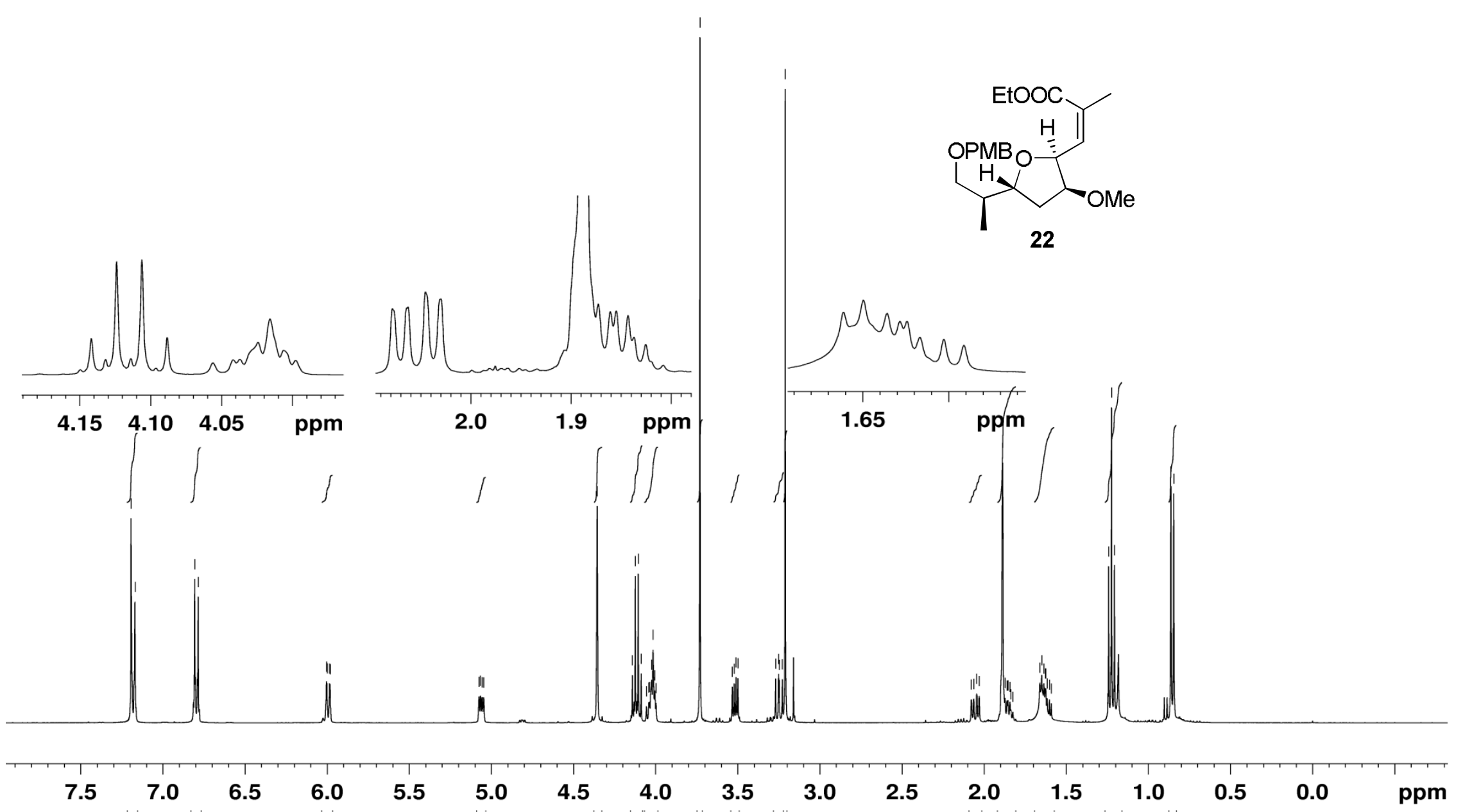

${ }^{1} \mathrm{H}$ NMR spectrum of $22\left(\mathrm{CDCl}_{3}, 400 \mathrm{MHz}\right)$ 

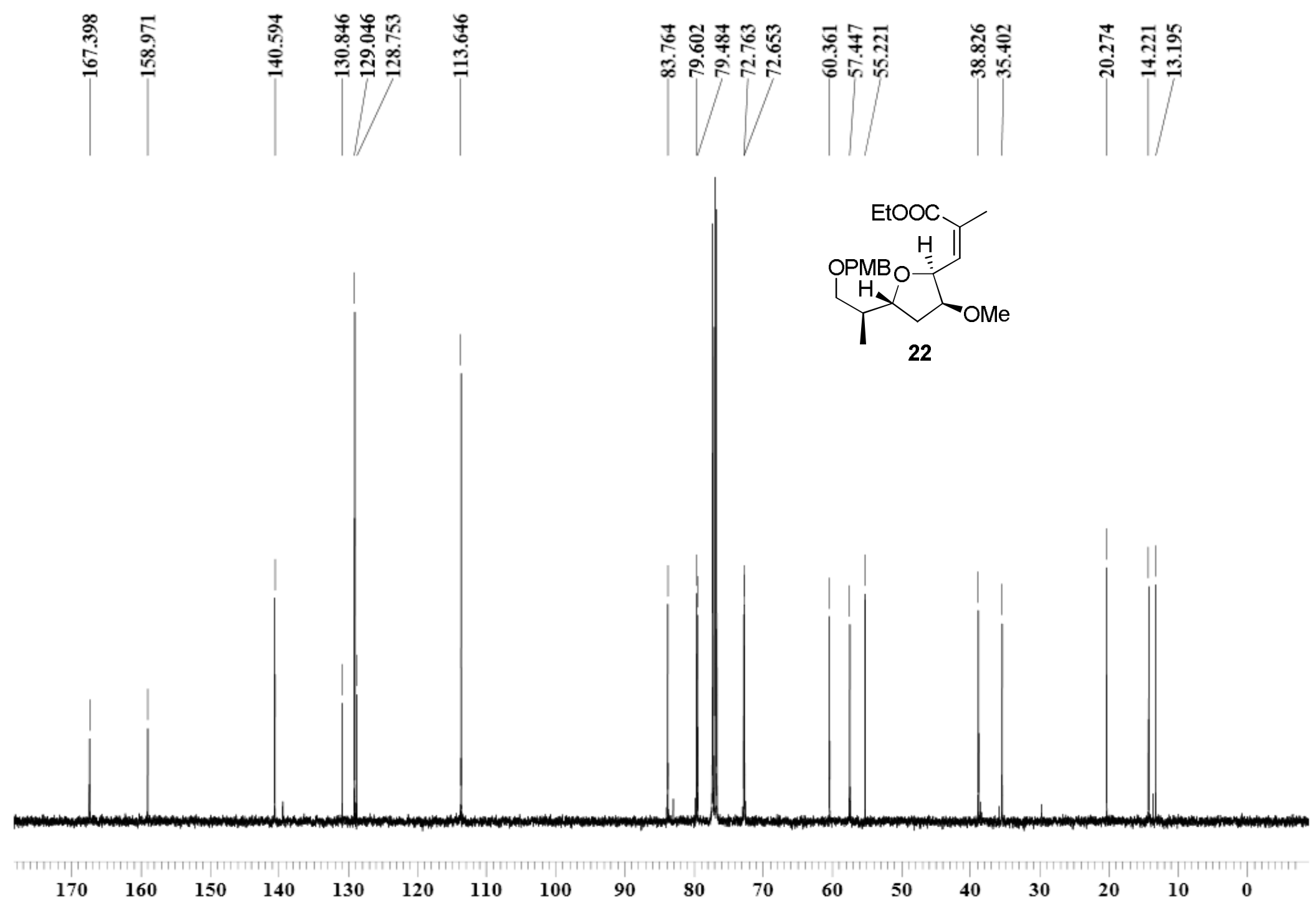

${ }^{13} \mathrm{C}$ NMR spectrum of $22\left(\mathrm{CDCl}_{3}, 100 \mathrm{MHz}\right)$ 


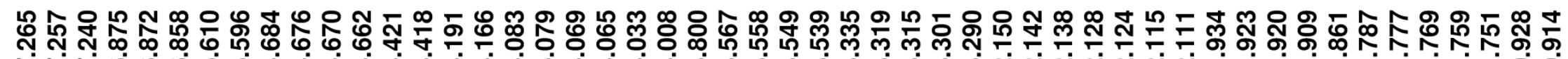

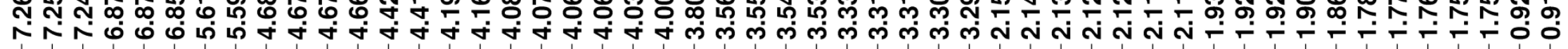
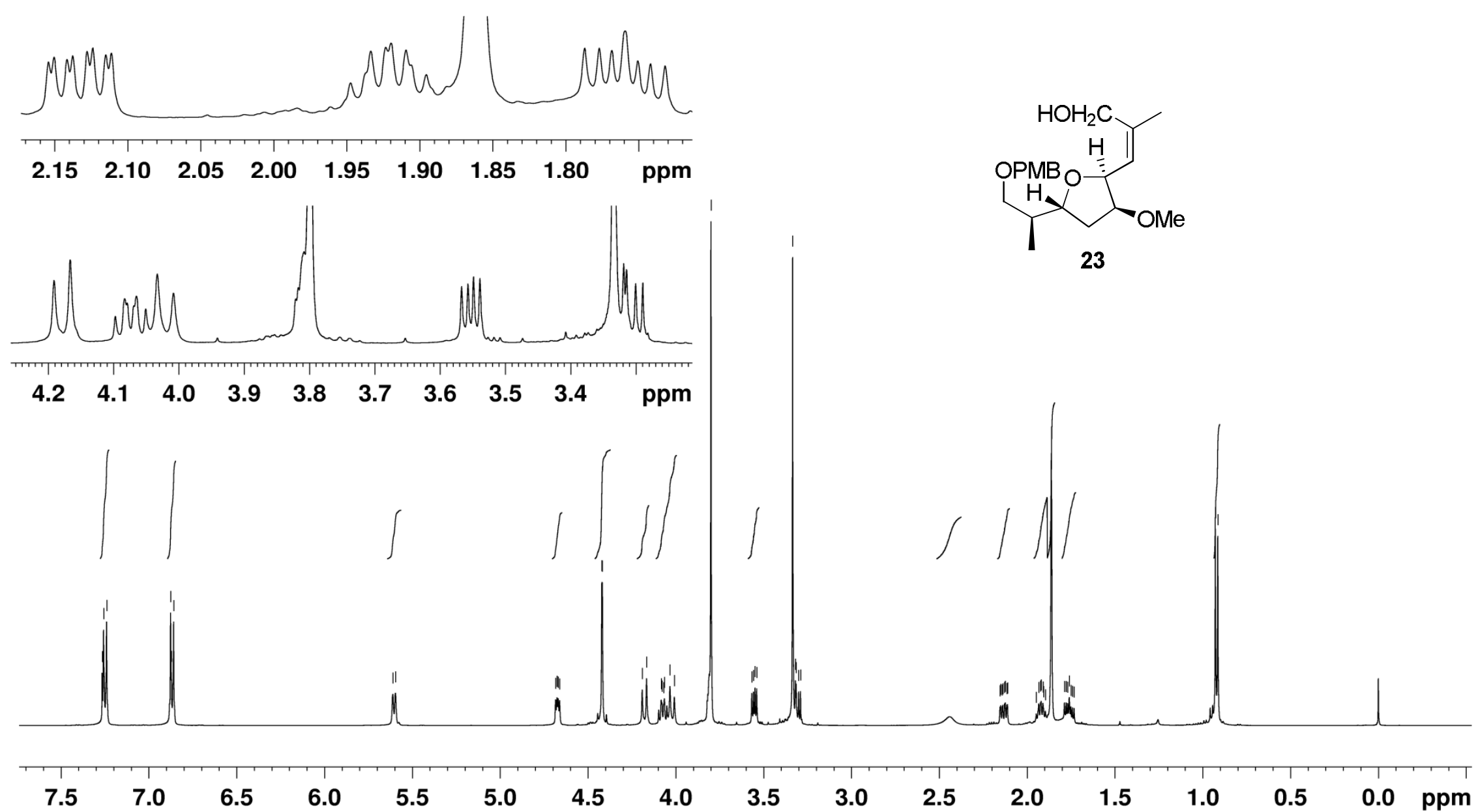

${ }^{1} \mathrm{H}$ NMR spectrum of $23\left(\mathrm{CDCl}_{3}, 500 \mathrm{MHz}\right)$ 


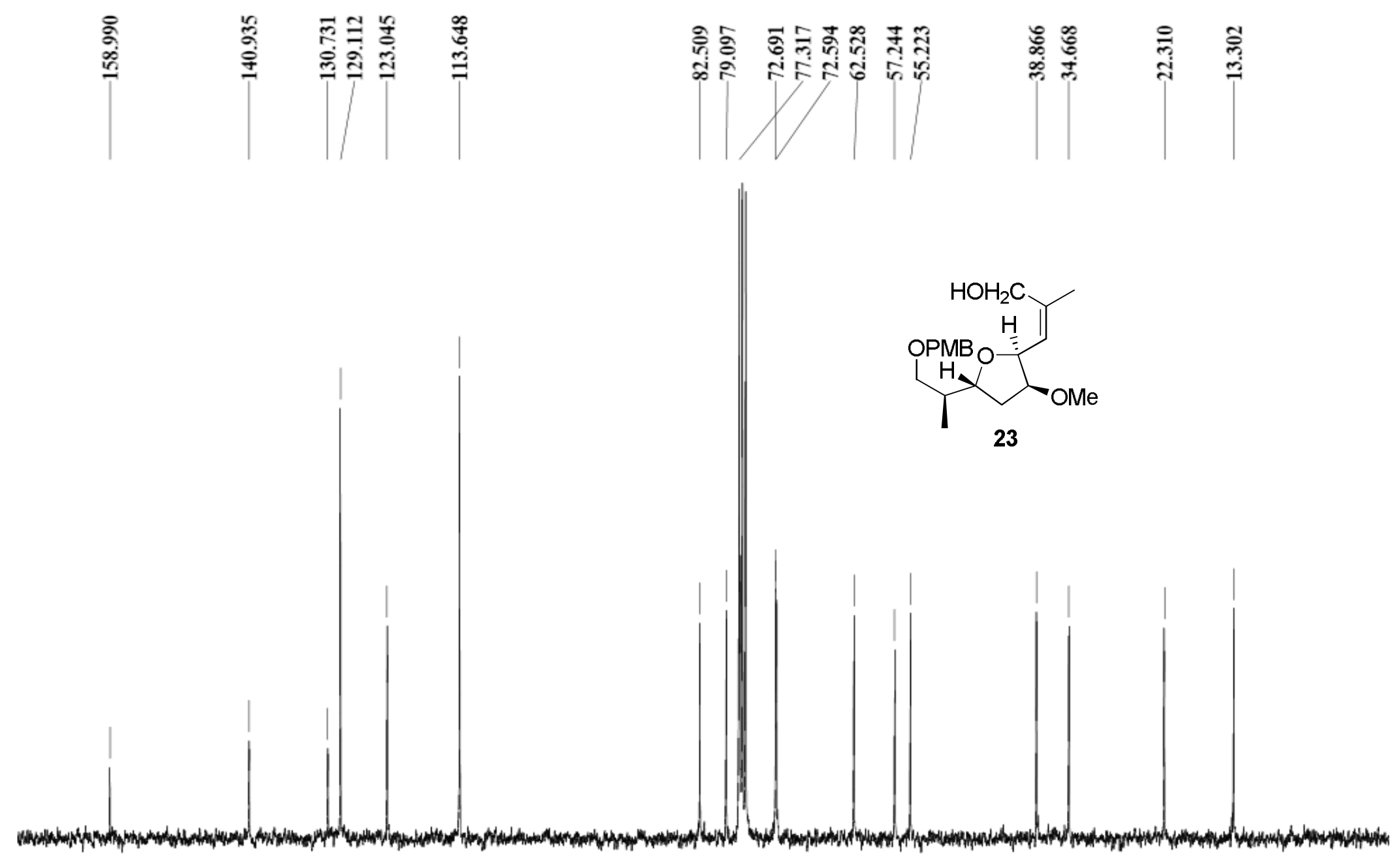

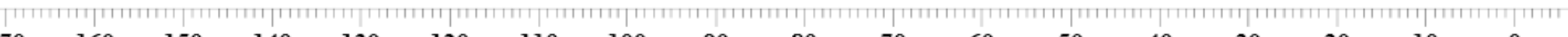

60

50

$40 \quad 30$

20

10

${ }^{13} \mathrm{C}$ NMR spectrum of $23\left(\mathrm{CDCl}_{3}, 100 \mathrm{MHz}\right)$ 


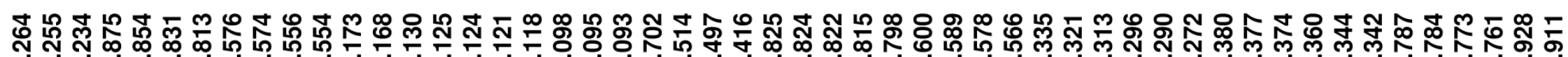

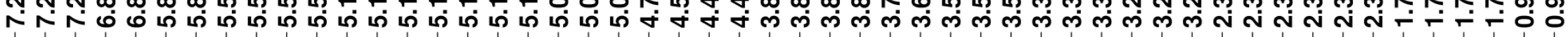

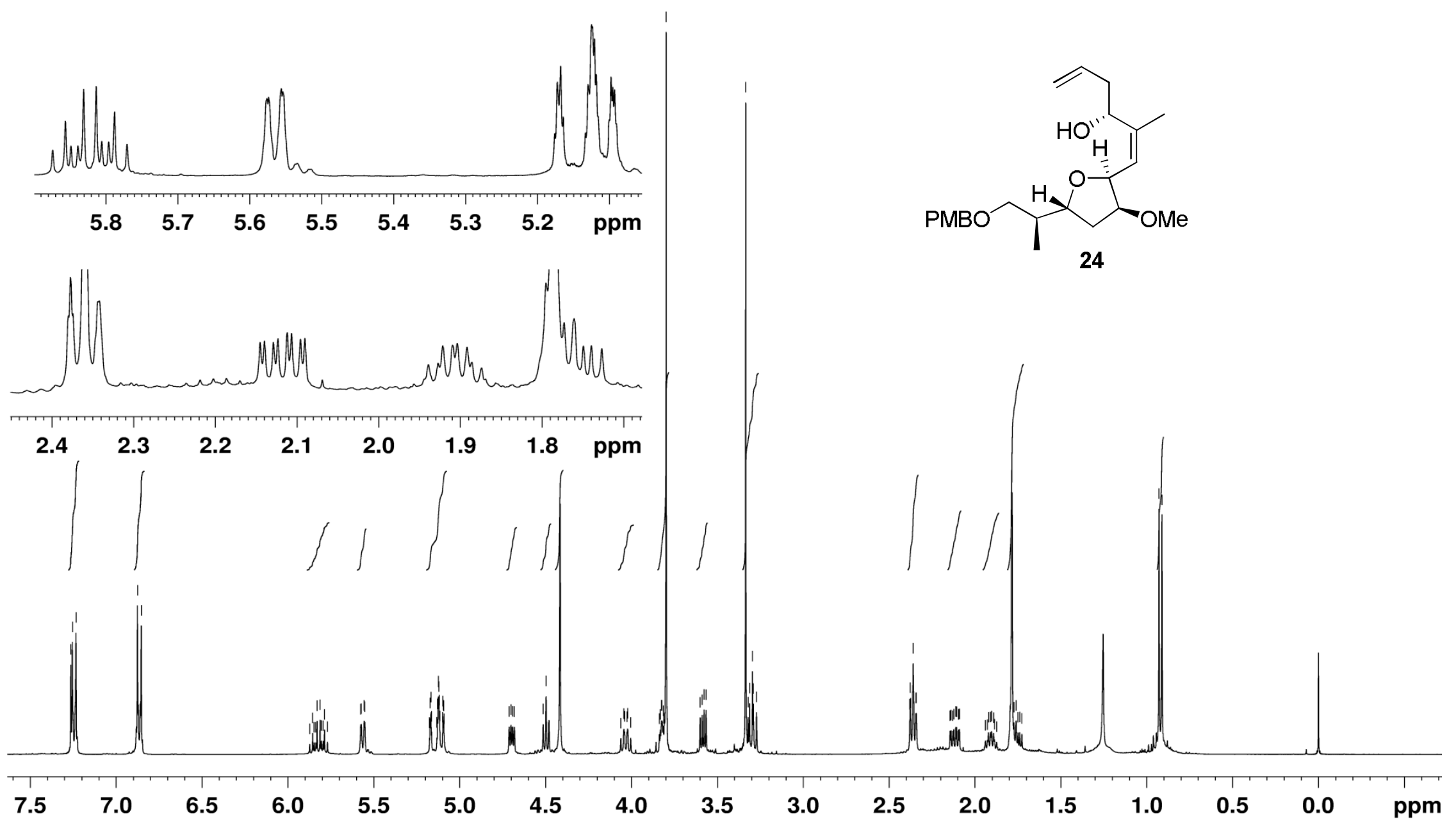

${ }^{1} \mathrm{H}$ NMR spectrum of $24\left(\mathrm{CDCl}_{3}, 400 \mathrm{MHz}\right)$ 


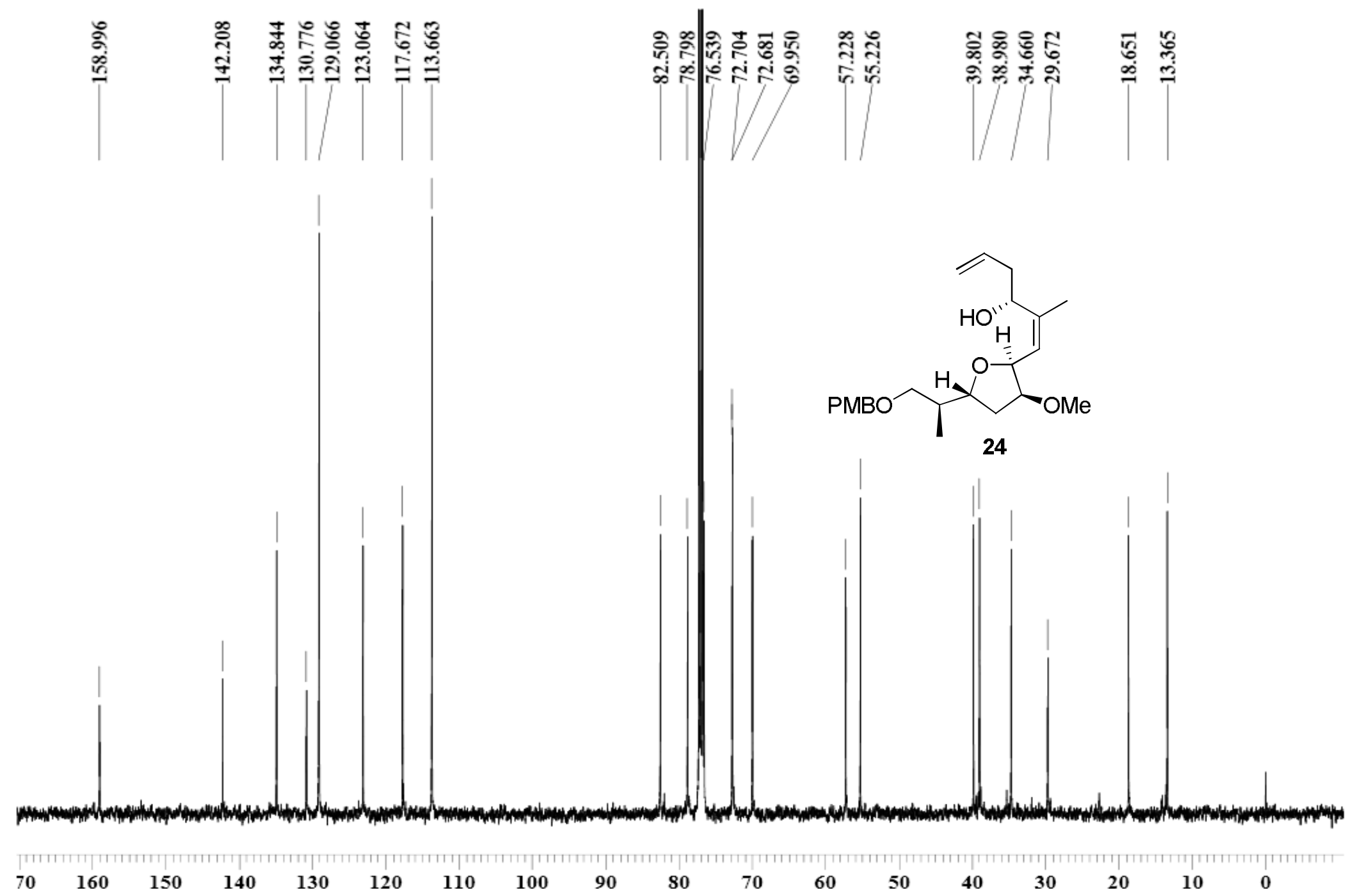

${ }^{13} \mathrm{C}$ NMR spectrum of $24\left(\mathrm{CDCl}_{3}, 125 \mathrm{MHz}\right)$ 


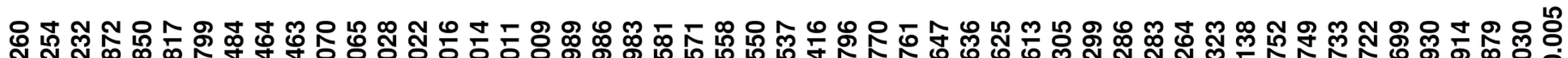

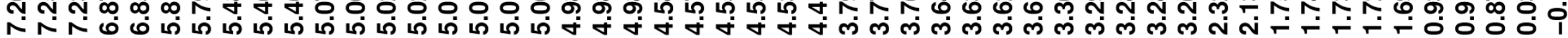

141

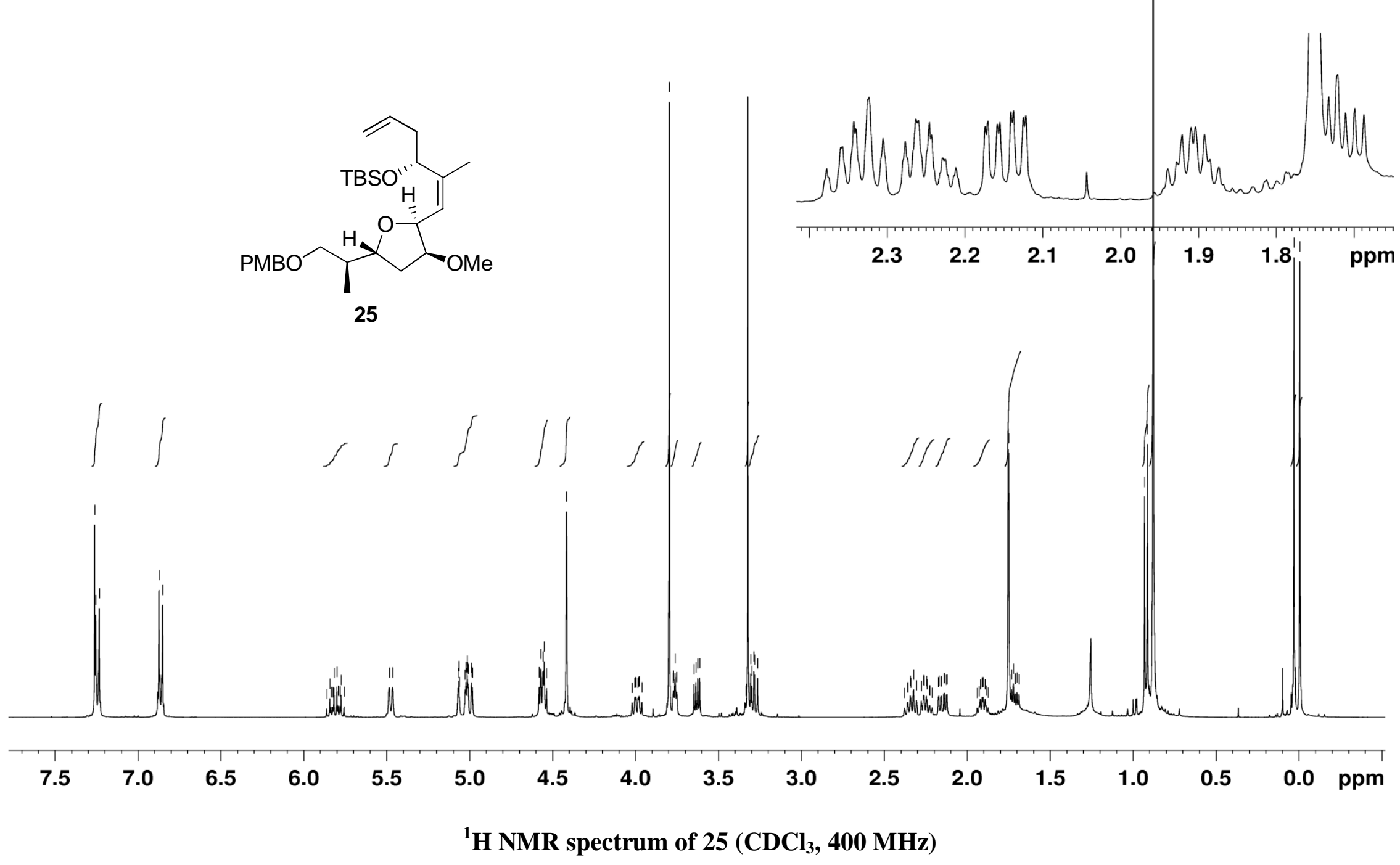




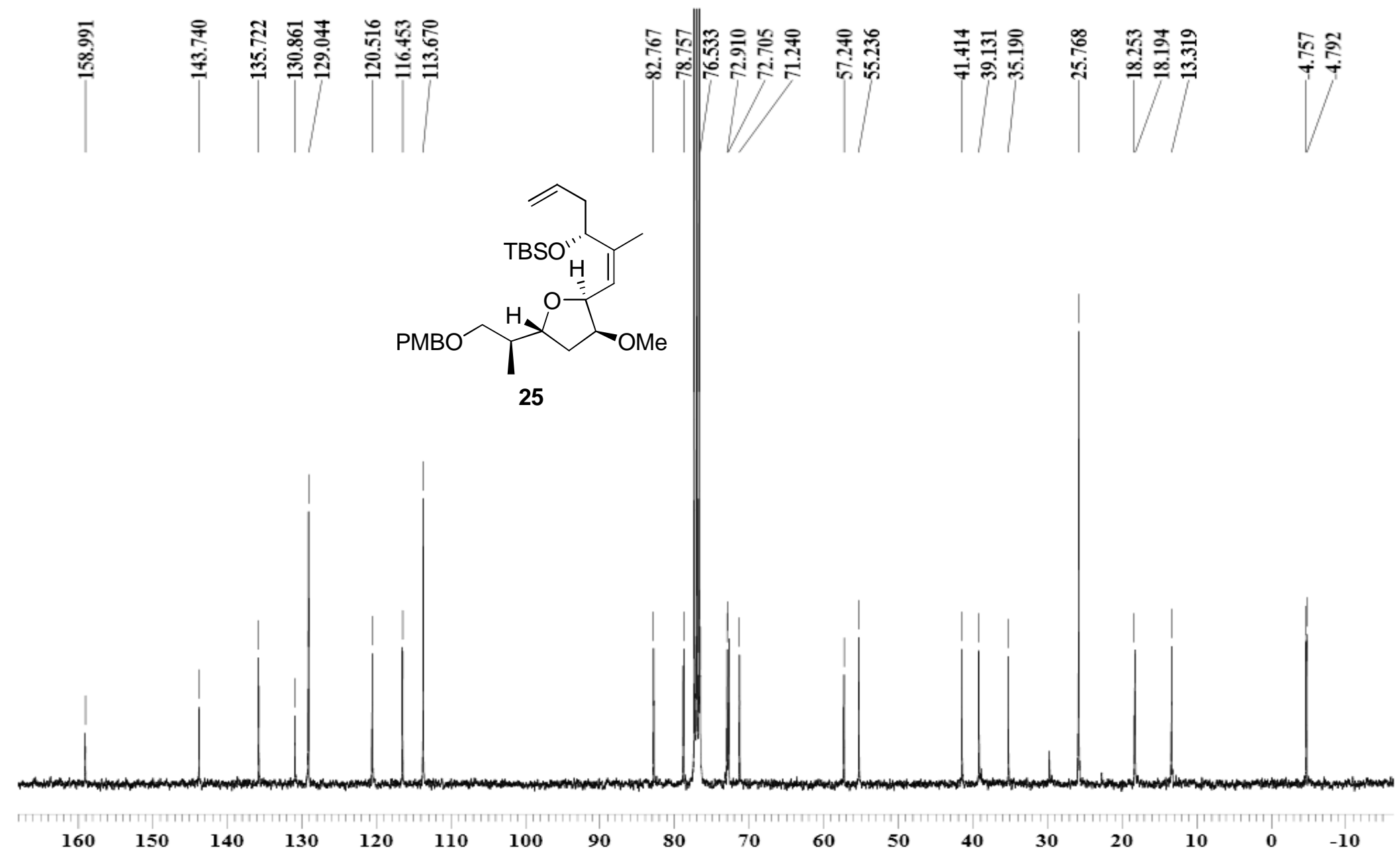

${ }^{13} \mathrm{C}$ NMR spectrum of $25\left(\mathrm{CDCl}_{3}, 100 \mathrm{MHz}\right)$ 


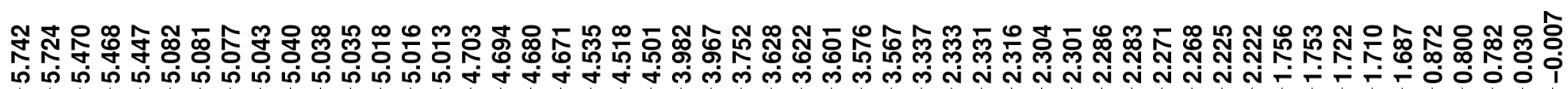

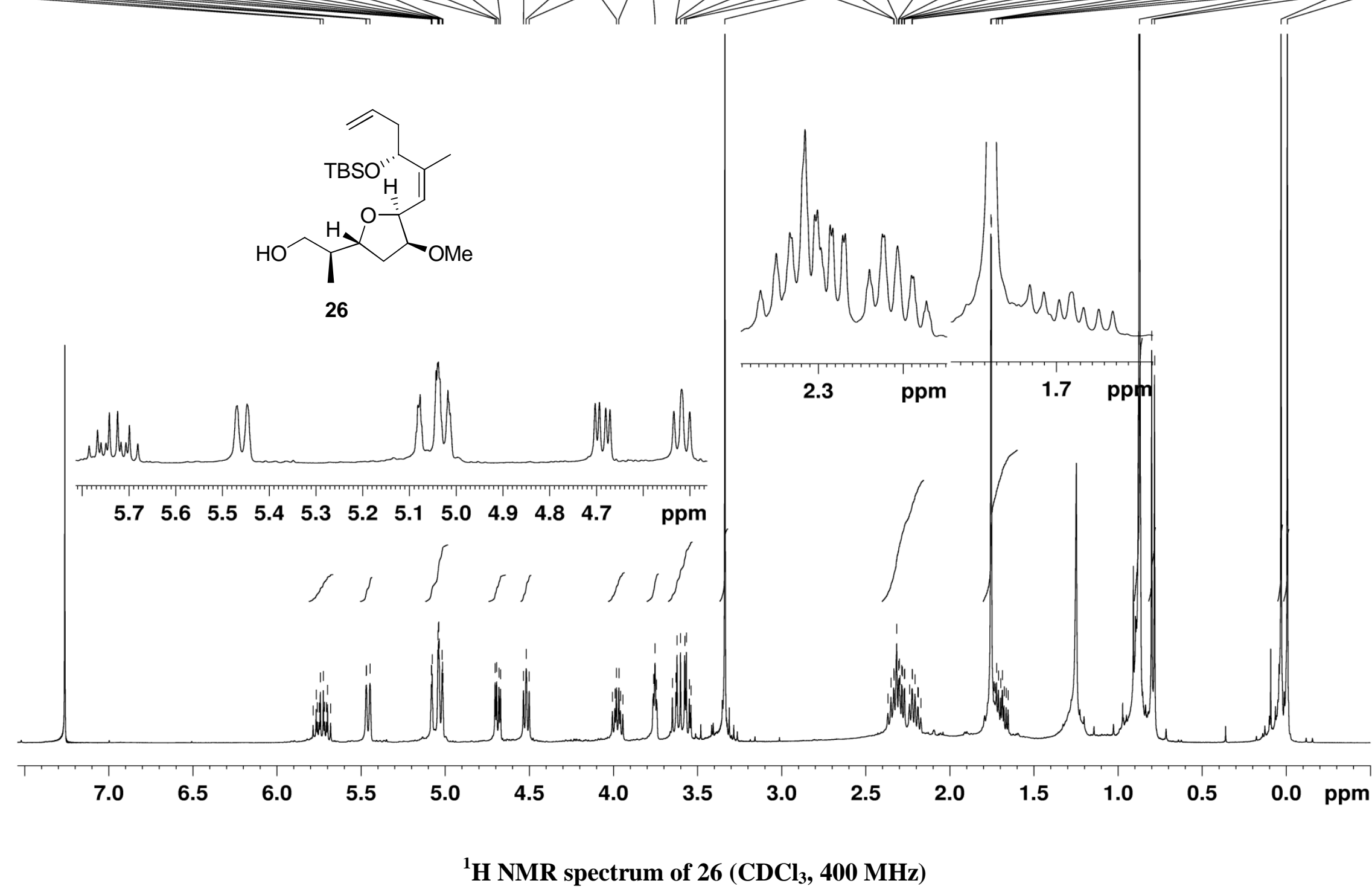



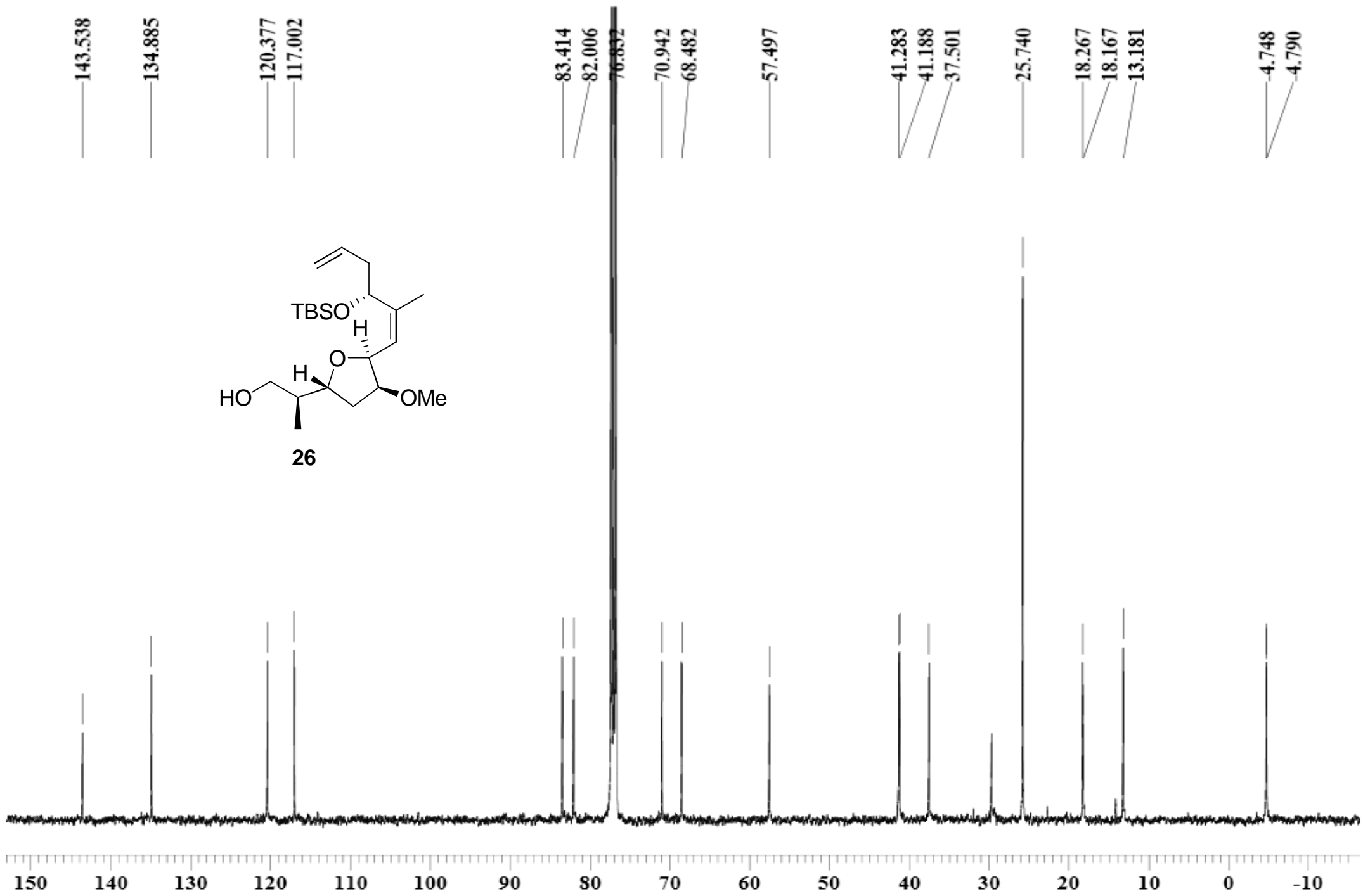

${ }^{13} \mathrm{C}$ NMR spectrum of $26\left(\mathrm{CDCl}_{3}, 100 \mathrm{MHz}\right)$ 


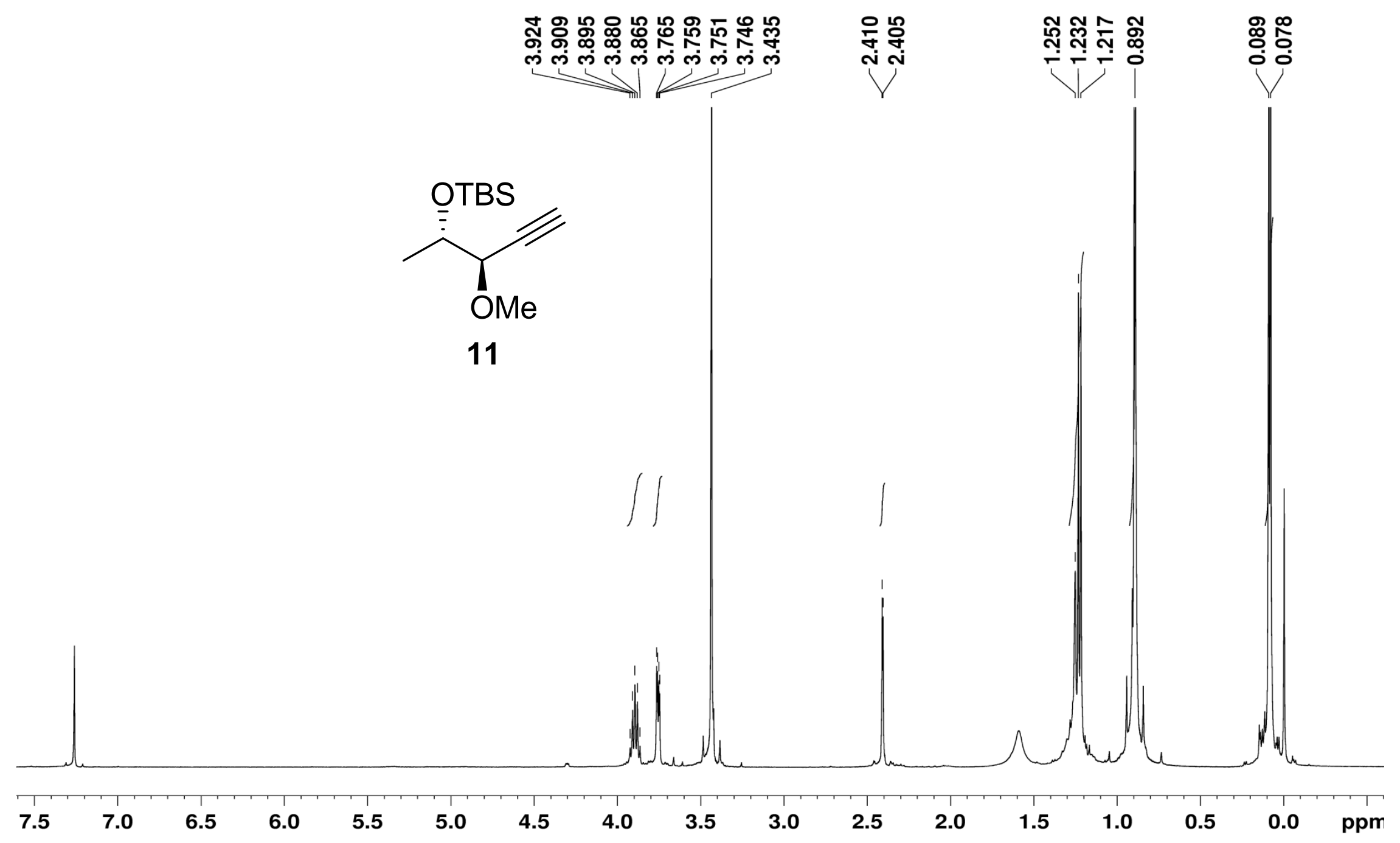

${ }^{1} \mathrm{H}$ NMR spectrum of $11\left(\mathrm{CDCl}_{3}, 400 \mathrm{MHz}\right)$ 

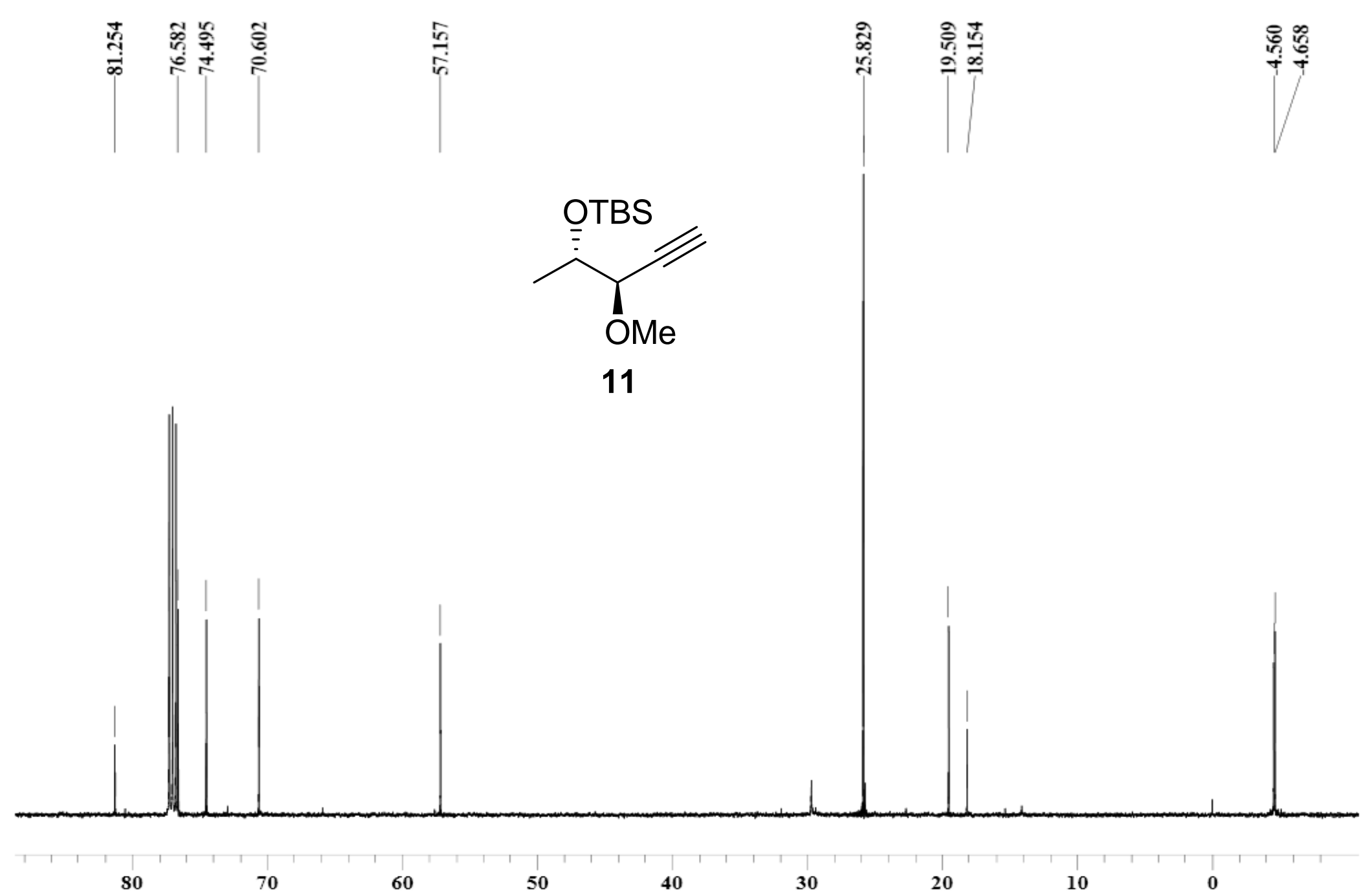

${ }^{13} \mathrm{C}$ NMR spectrum of $11\left(\mathrm{CDCl}_{3}, 100 \mathrm{MHz}\right)$ 


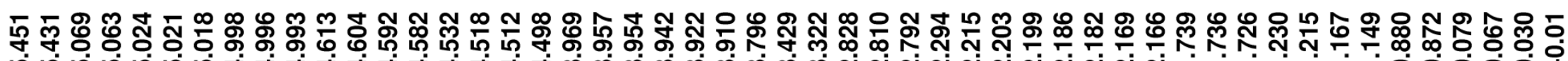
ம่

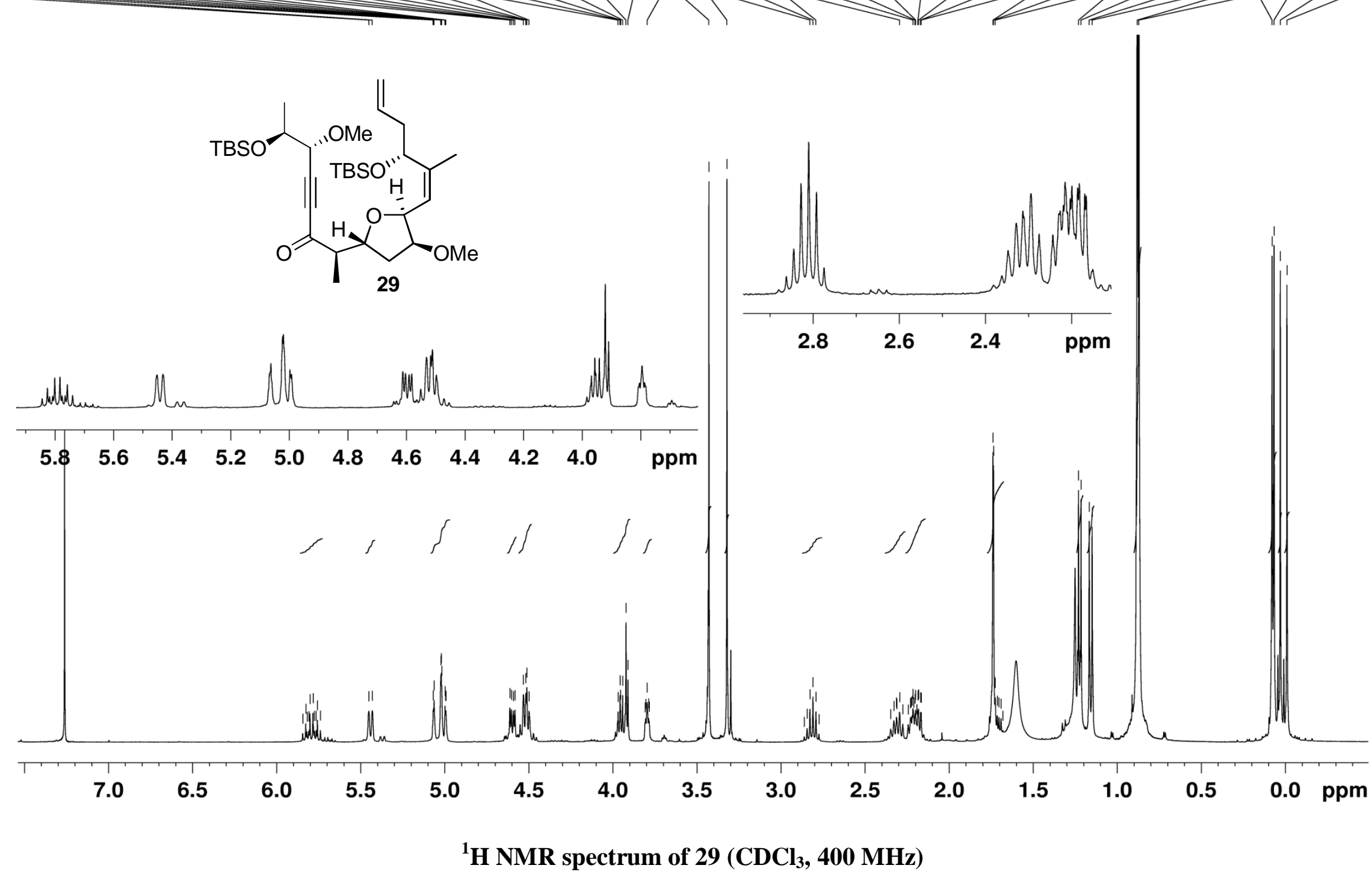



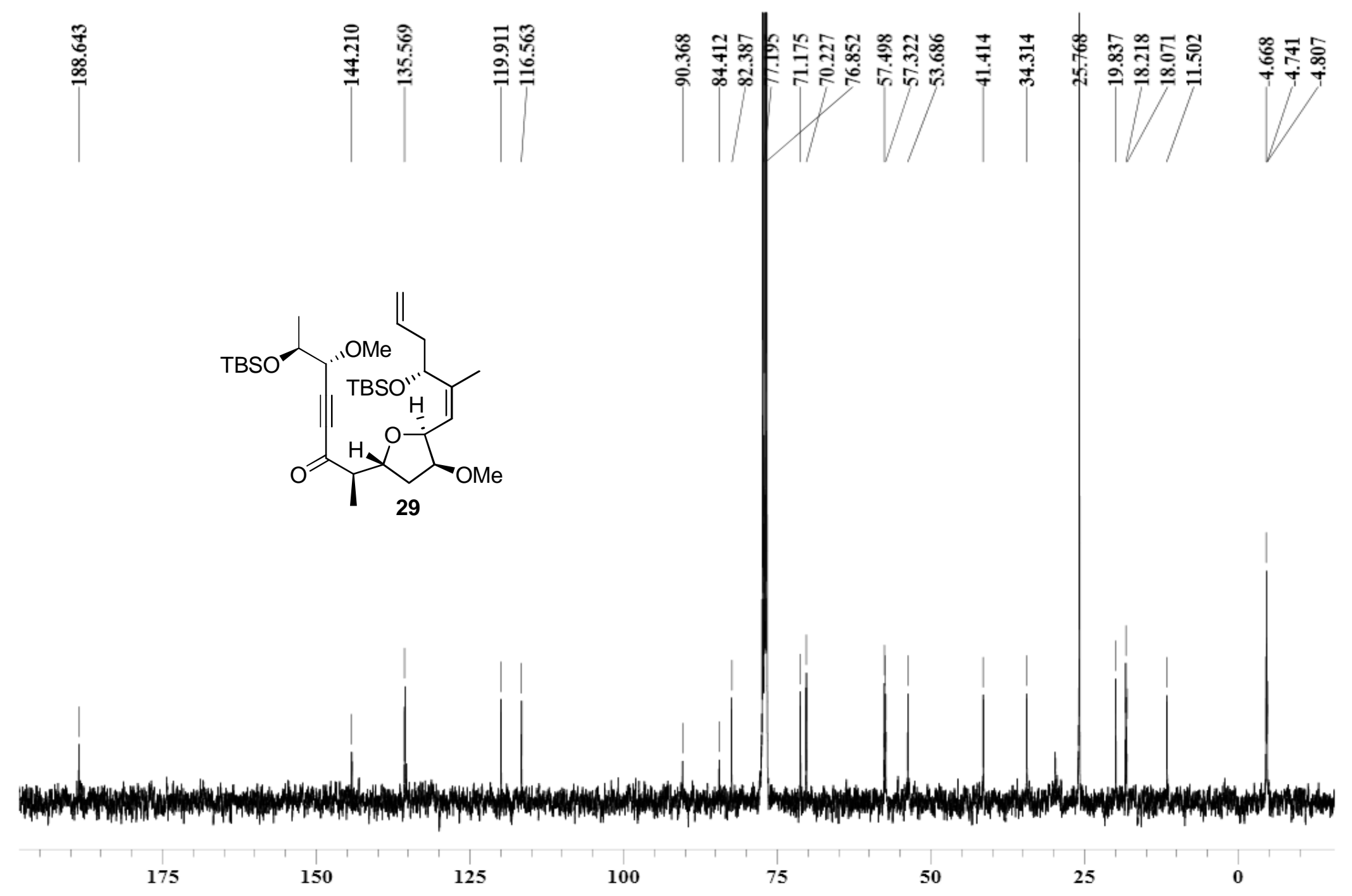

${ }^{13} \mathrm{C}$ NMR spectrum of $29\left(\mathrm{CDCl}_{3}, 100 \mathrm{MHz}\right)$ 


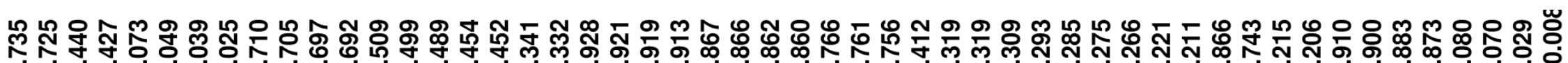
ம் ம் ம் ம் ம் ம்

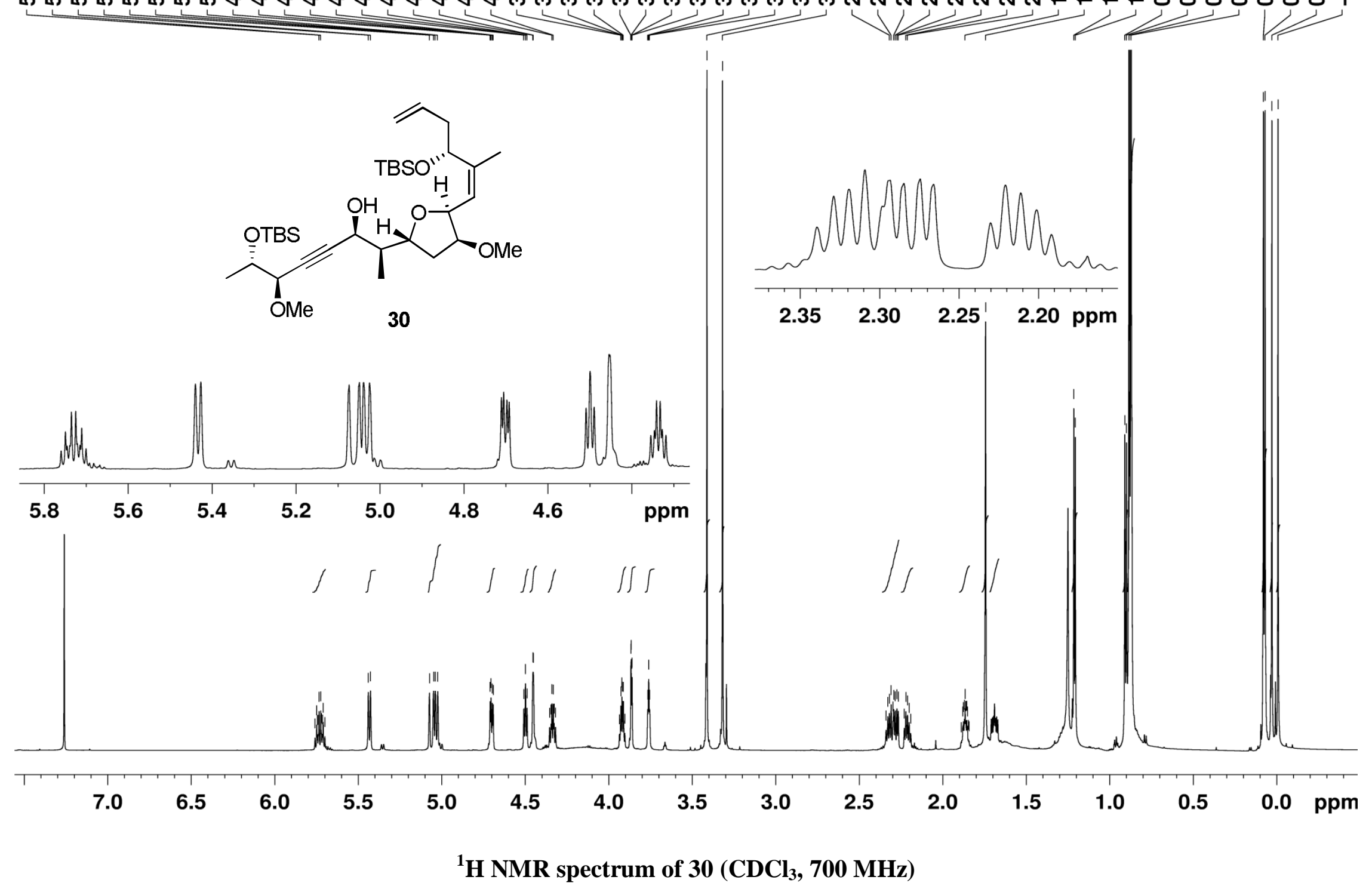



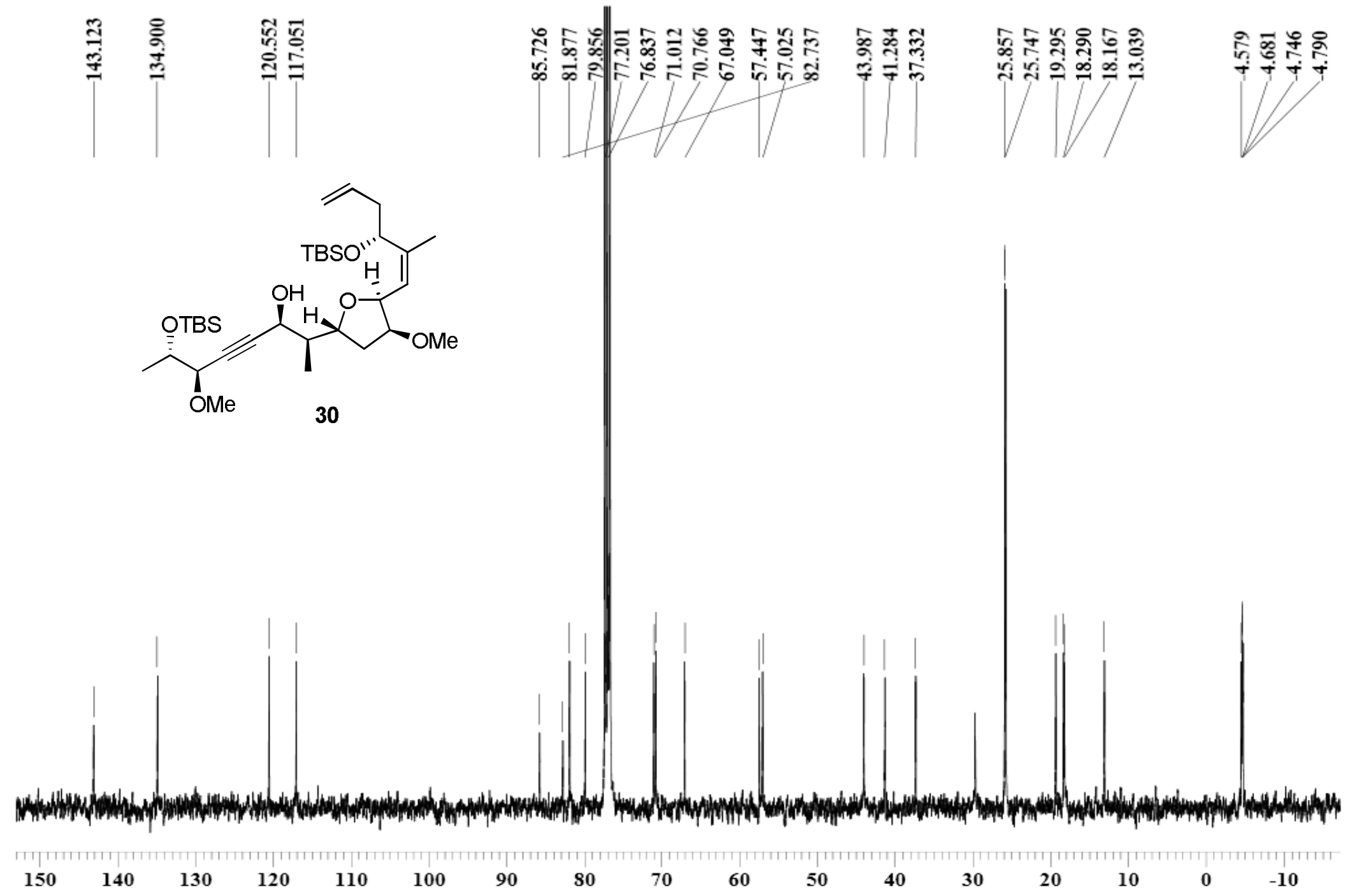

${ }^{13} \mathrm{C} \mathrm{NMR}$ spectrum of $30\left(\mathrm{CDCl}_{3}, 100 \mathrm{MHz}\right)$ 


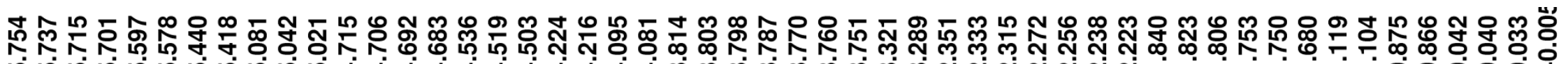
ம்

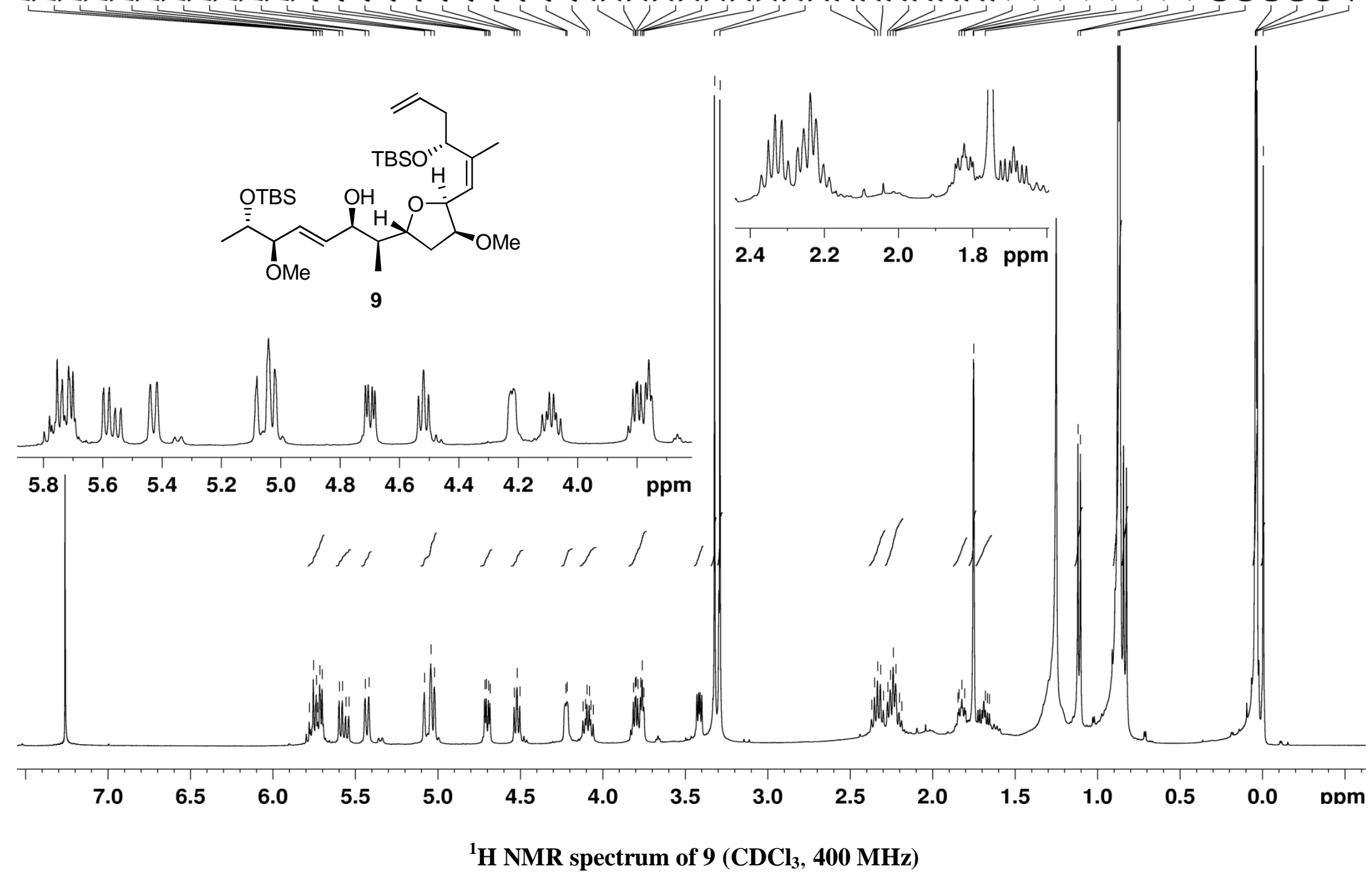




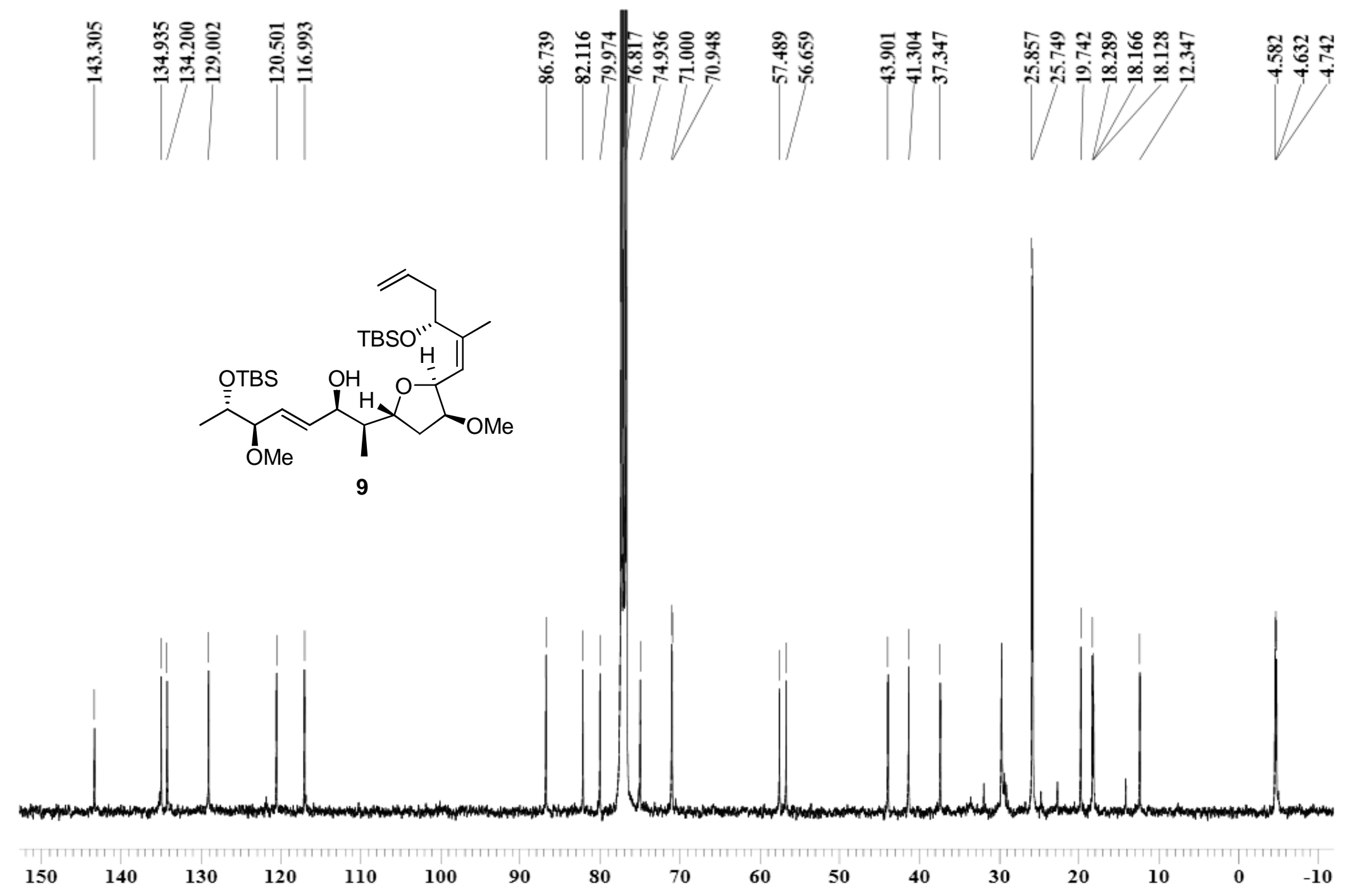

${ }^{13} \mathrm{C}$ NMR spectrum of $9\left(\mathrm{CDCl}_{3}, 100 \mathrm{MHz}\right)$ 


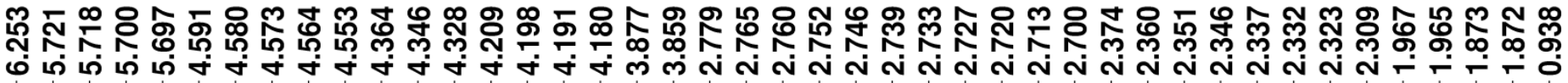

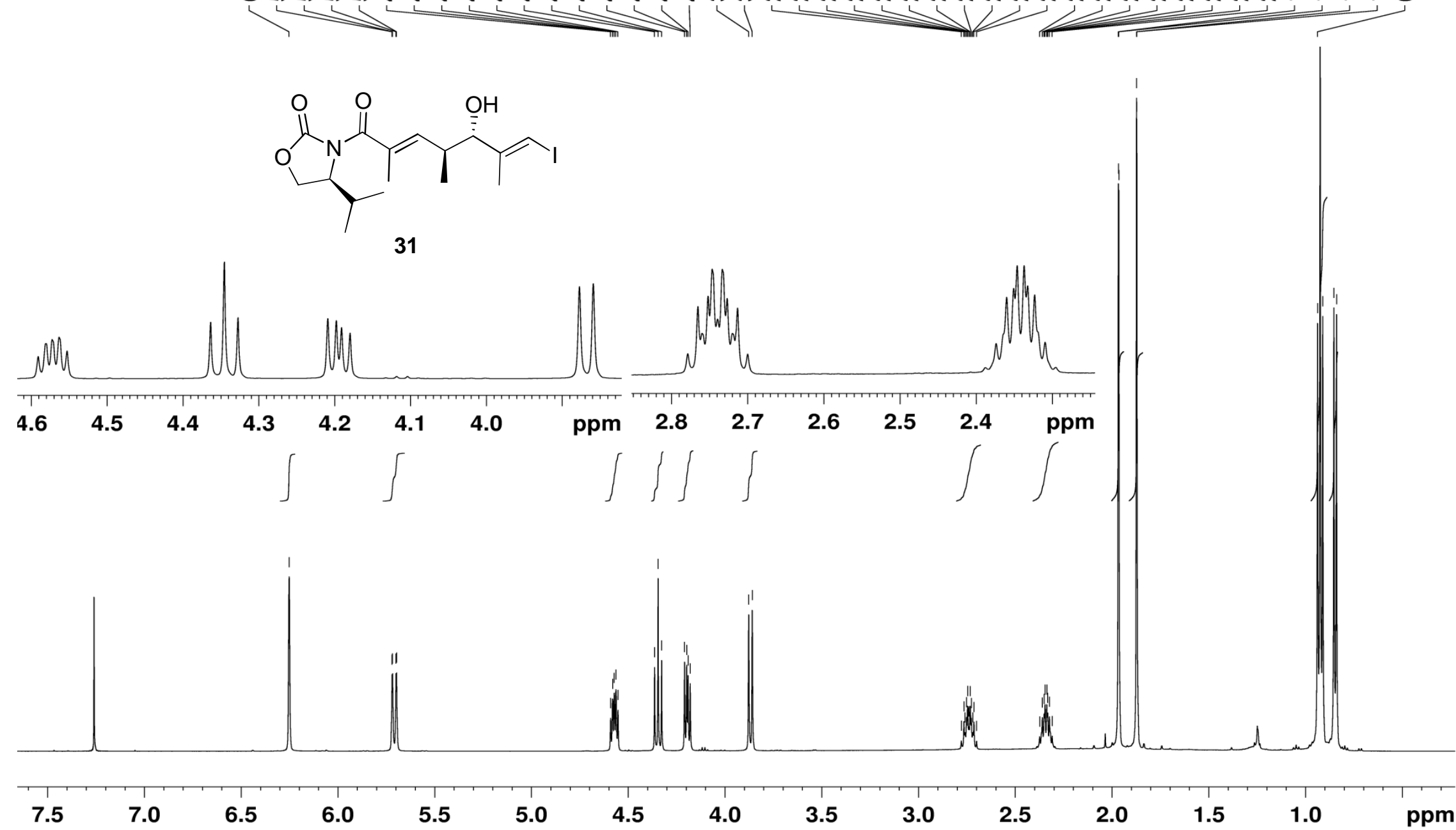

${ }^{1} \mathrm{H}$ NMR spectrum of $31\left(\mathrm{CDCl}_{3}, 500 \mathrm{MHz}\right)$ 


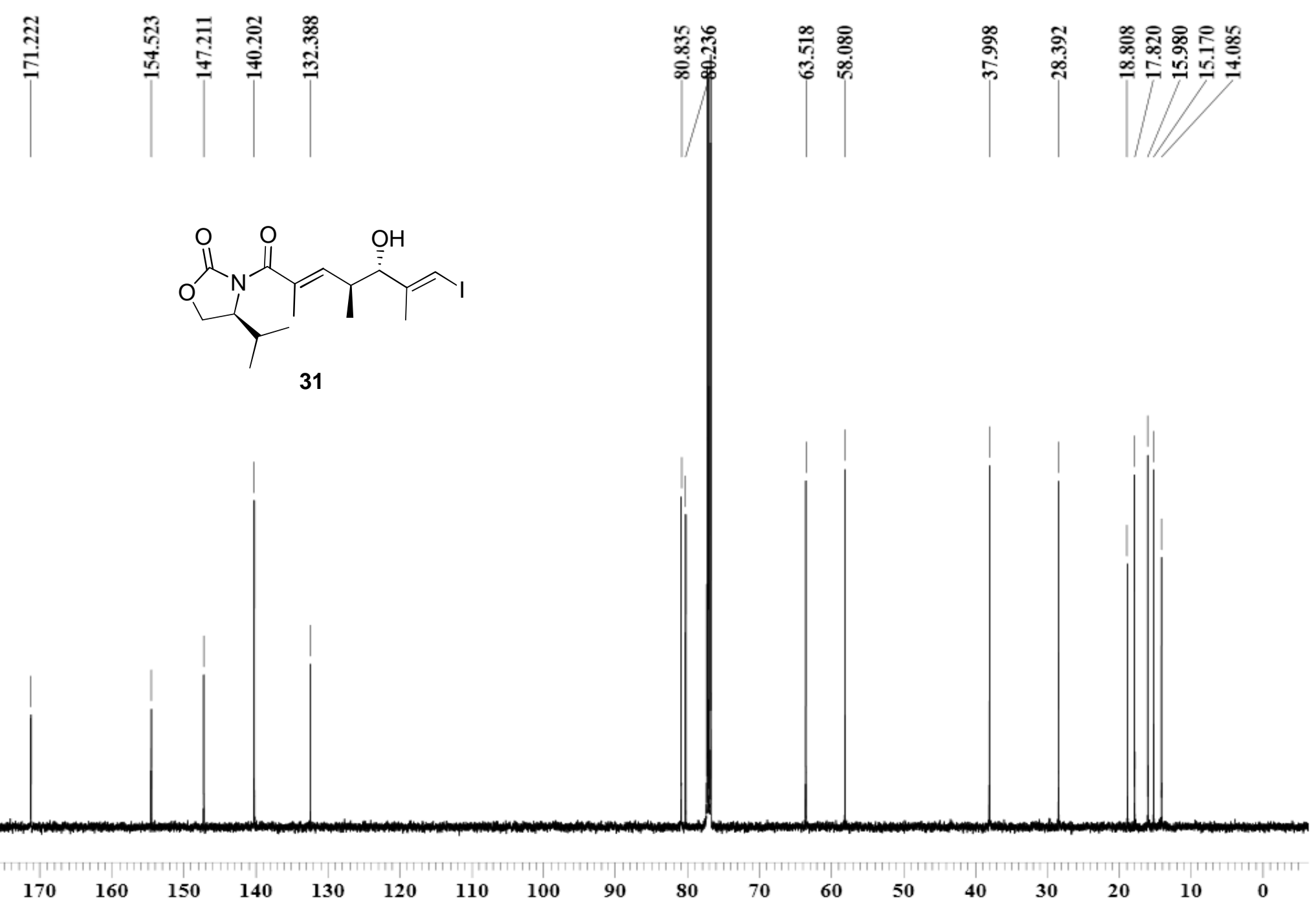

${ }^{13} \mathrm{C} \mathrm{NMR}$ spectrum of $31\left(\mathrm{CDCl}_{3}, 125 \mathrm{MHz}\right)$ 


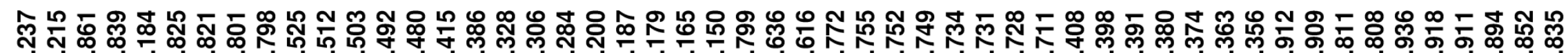

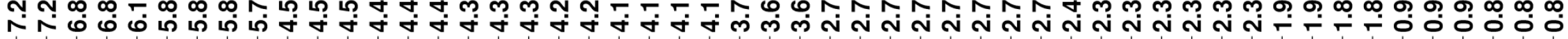

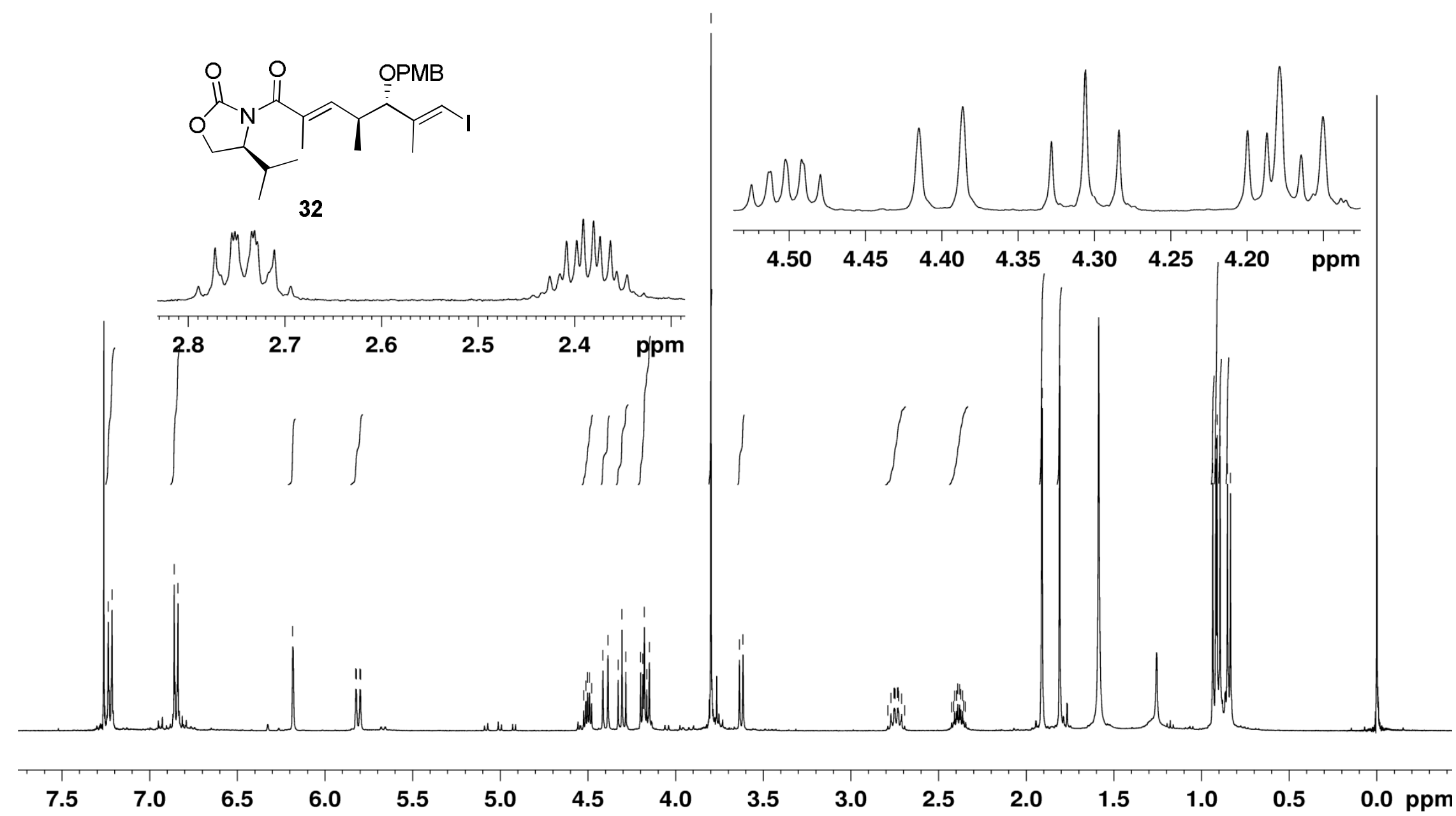

${ }^{1} \mathrm{H}$ NMR spectrum of $32\left(\mathrm{CDCl}_{3}, 400 \mathrm{MHz}\right)$ 

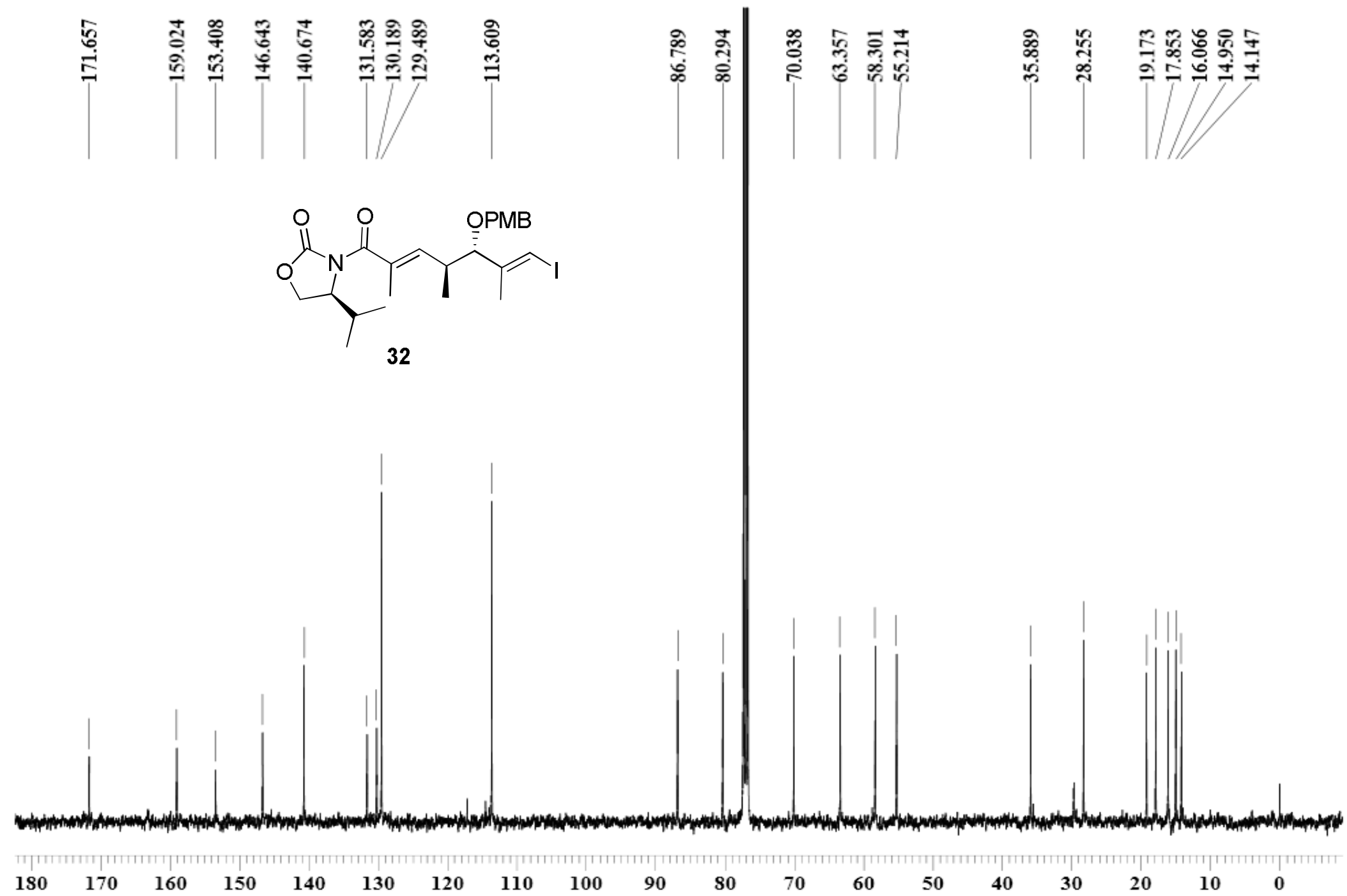

${ }^{13} \mathrm{C}$ NMR spectrum of $32\left(\mathrm{CDCl}_{3}, 100 \mathrm{MHz}\right)$ 


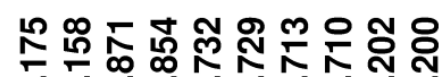

下走过

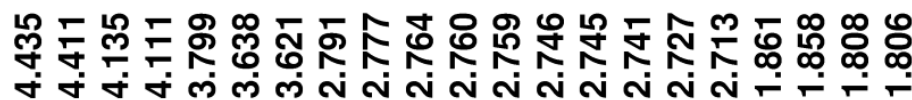

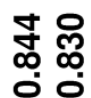

$1>V$
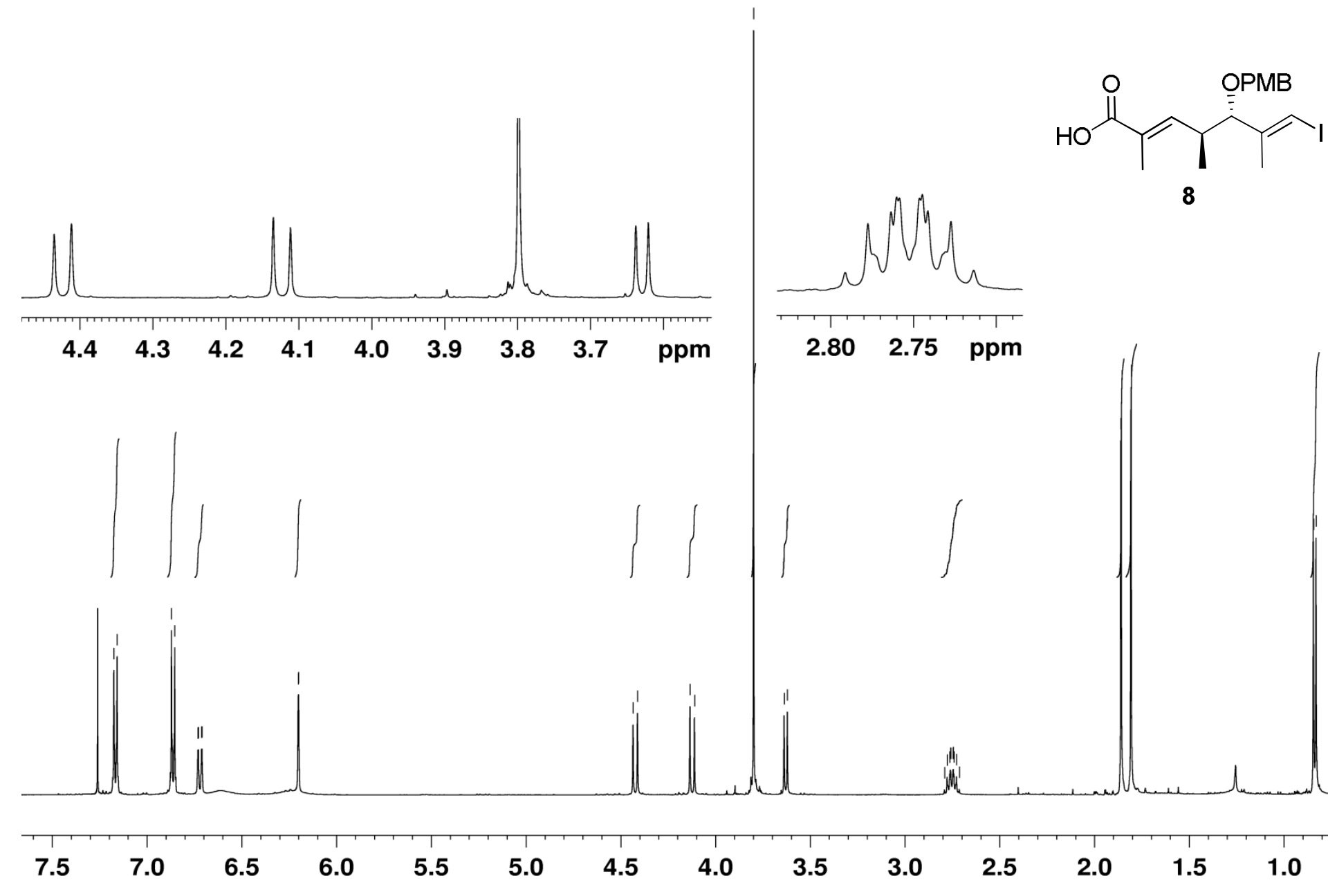

${ }^{1} \mathrm{H}$ NMR spectrum of $8\left(\mathrm{CDCl}_{3}, 500 \mathrm{MHz}\right)$ 


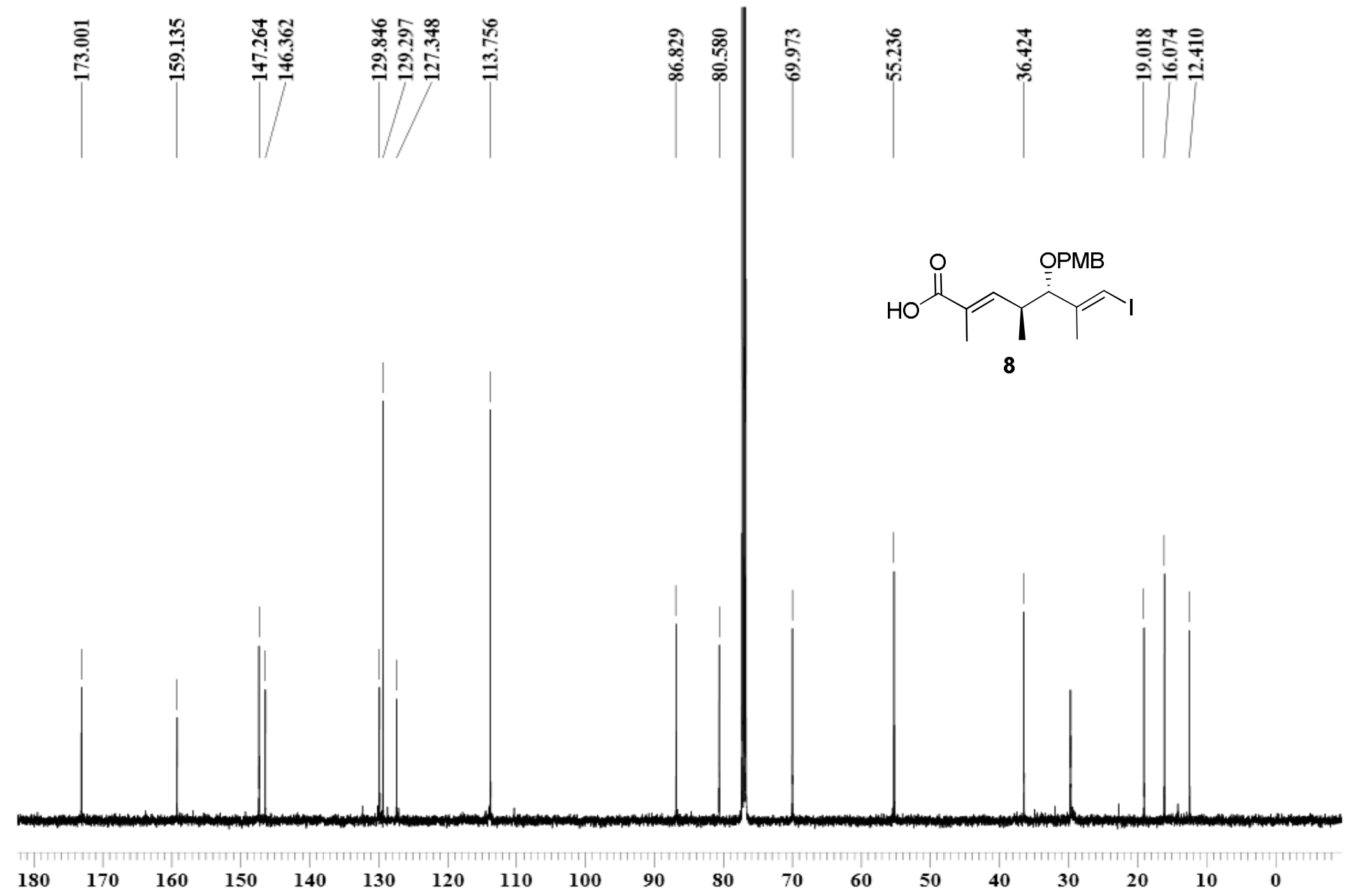

${ }^{13} \mathrm{C}$ NMR spectrum of $8\left(\mathrm{CDCl}_{3}, 125 \mathrm{MHz}\right)$ 


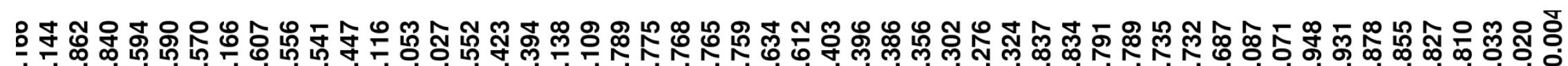

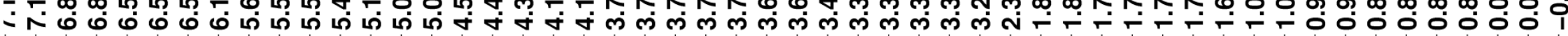

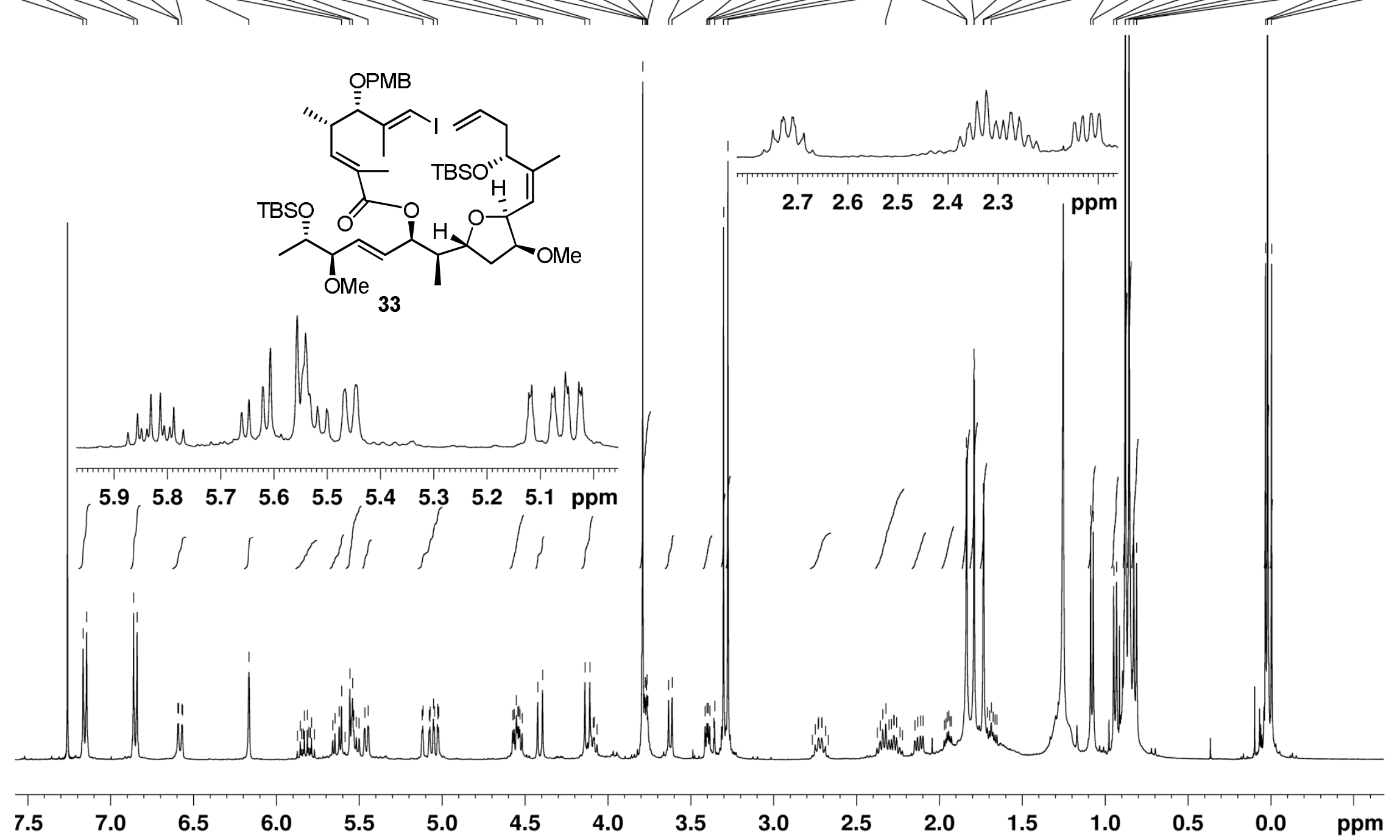

${ }^{1} \mathrm{H}$ NMR spectrum of $33\left(\mathrm{CDCl}_{3}, 400 \mathrm{MHz}\right)$ 

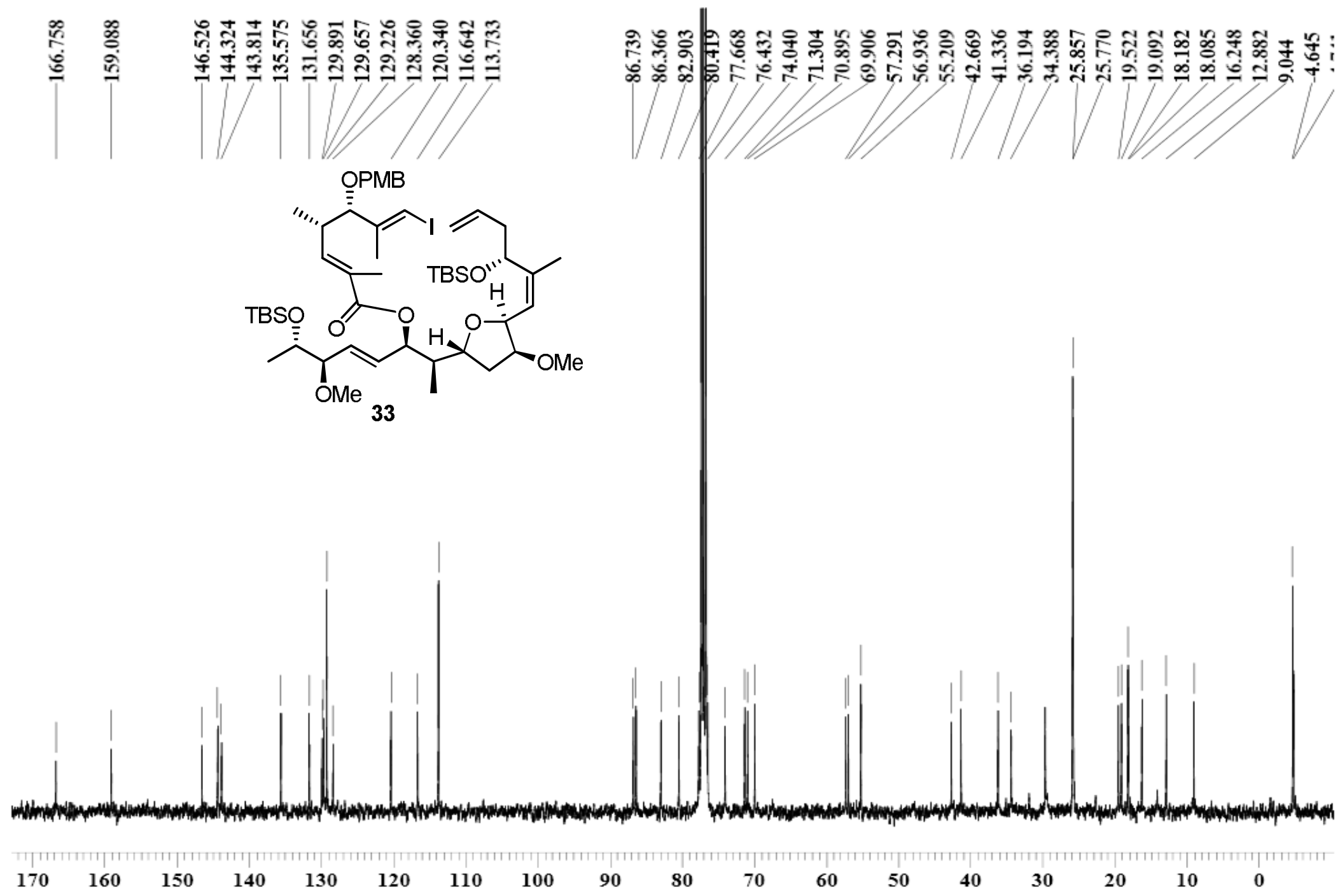

${ }^{13} \mathrm{C}$ NMR spectrum of $33\left(\mathrm{CDCl}_{3}, 100 \mathrm{MHz}\right)$ 


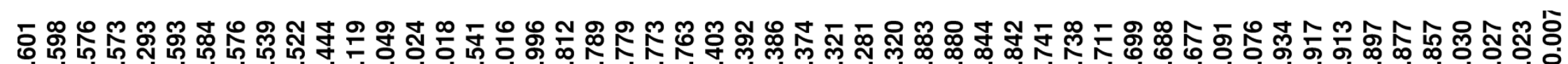
ن

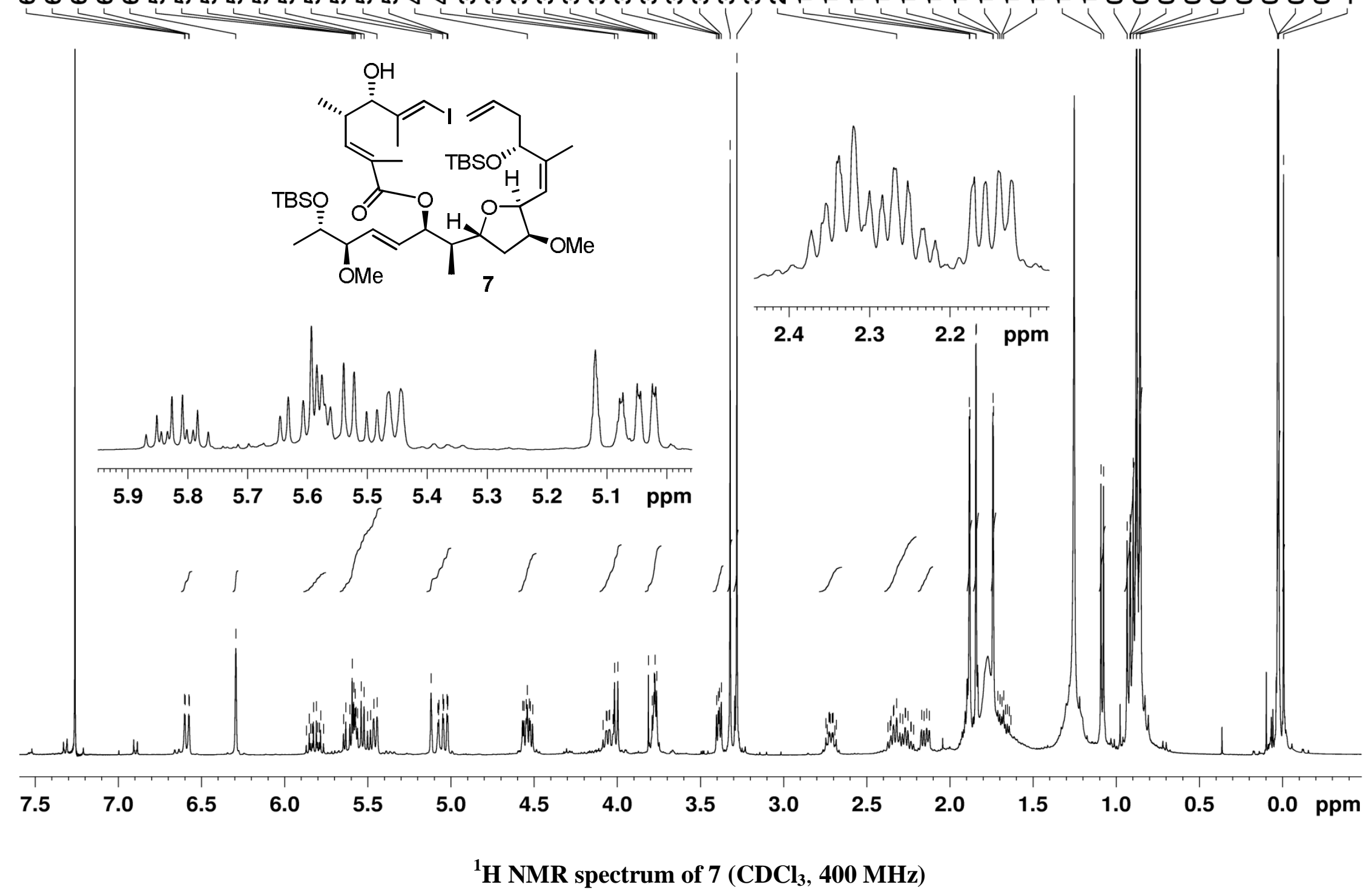



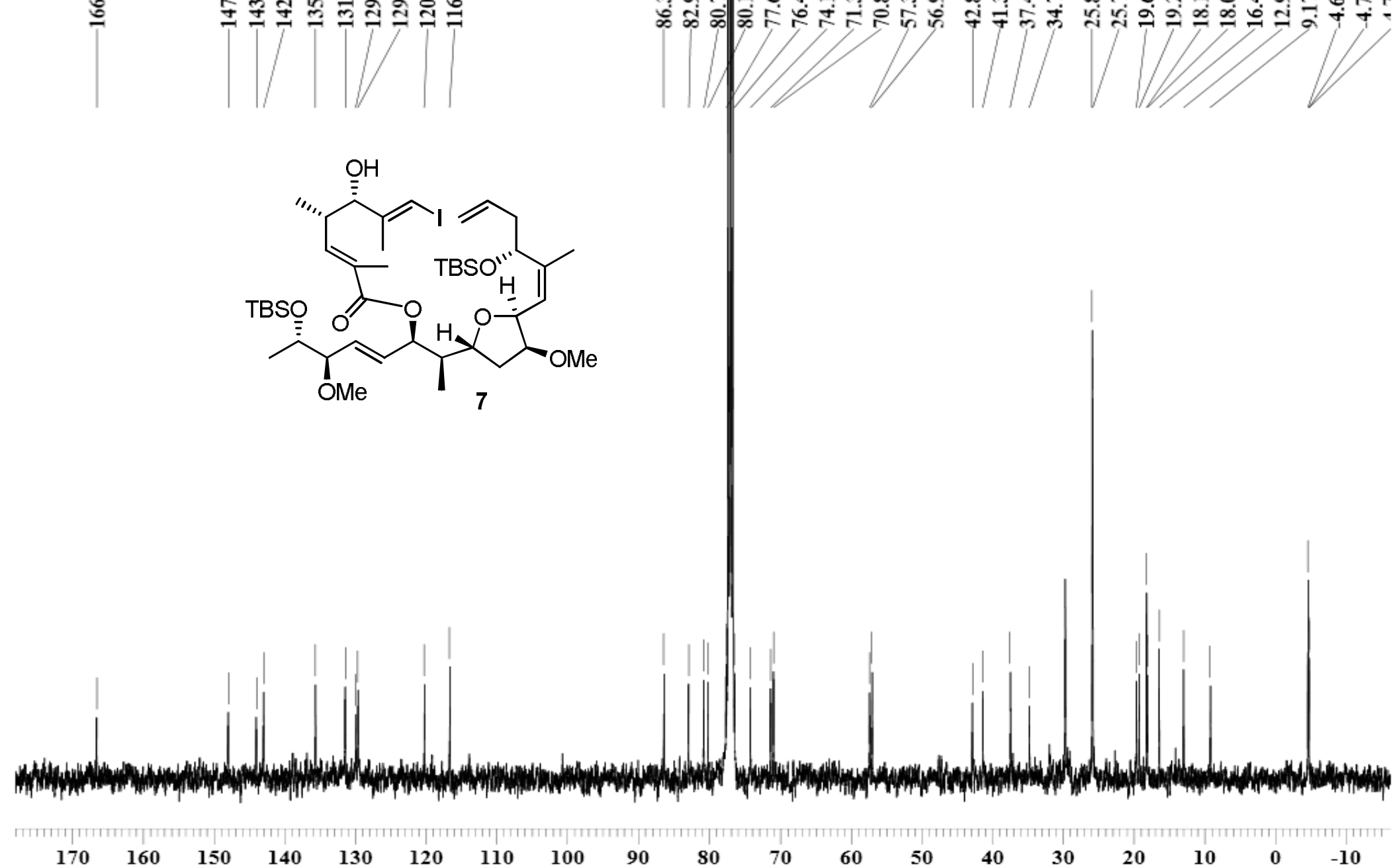

${ }^{13} \mathrm{C}$ NMR spectrum of $7\left(\mathrm{CDCl}_{3}, 100 \mathrm{MHz}\right)$ 


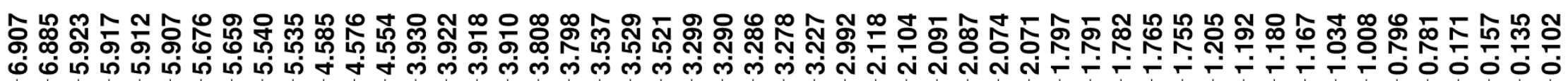

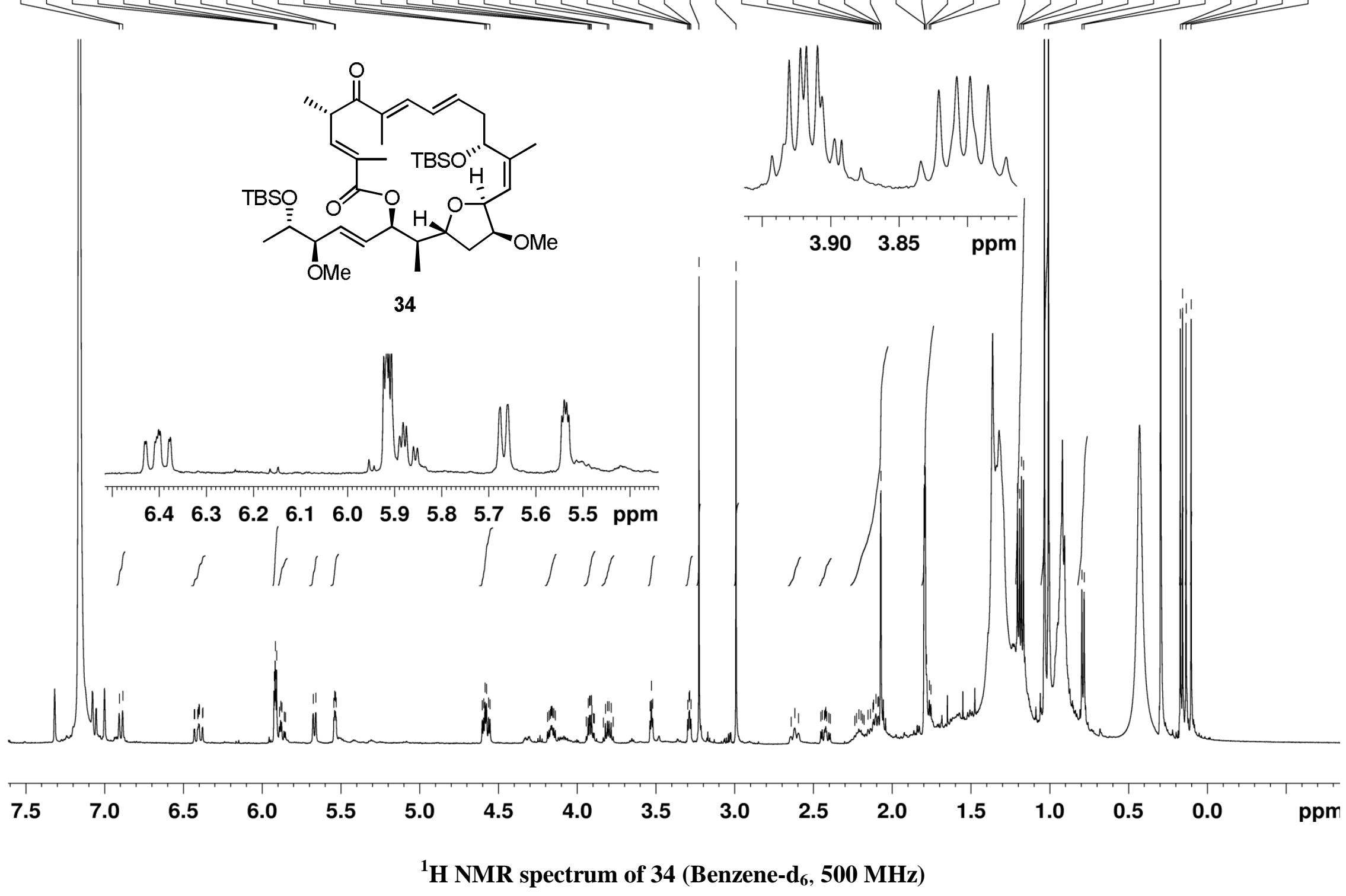




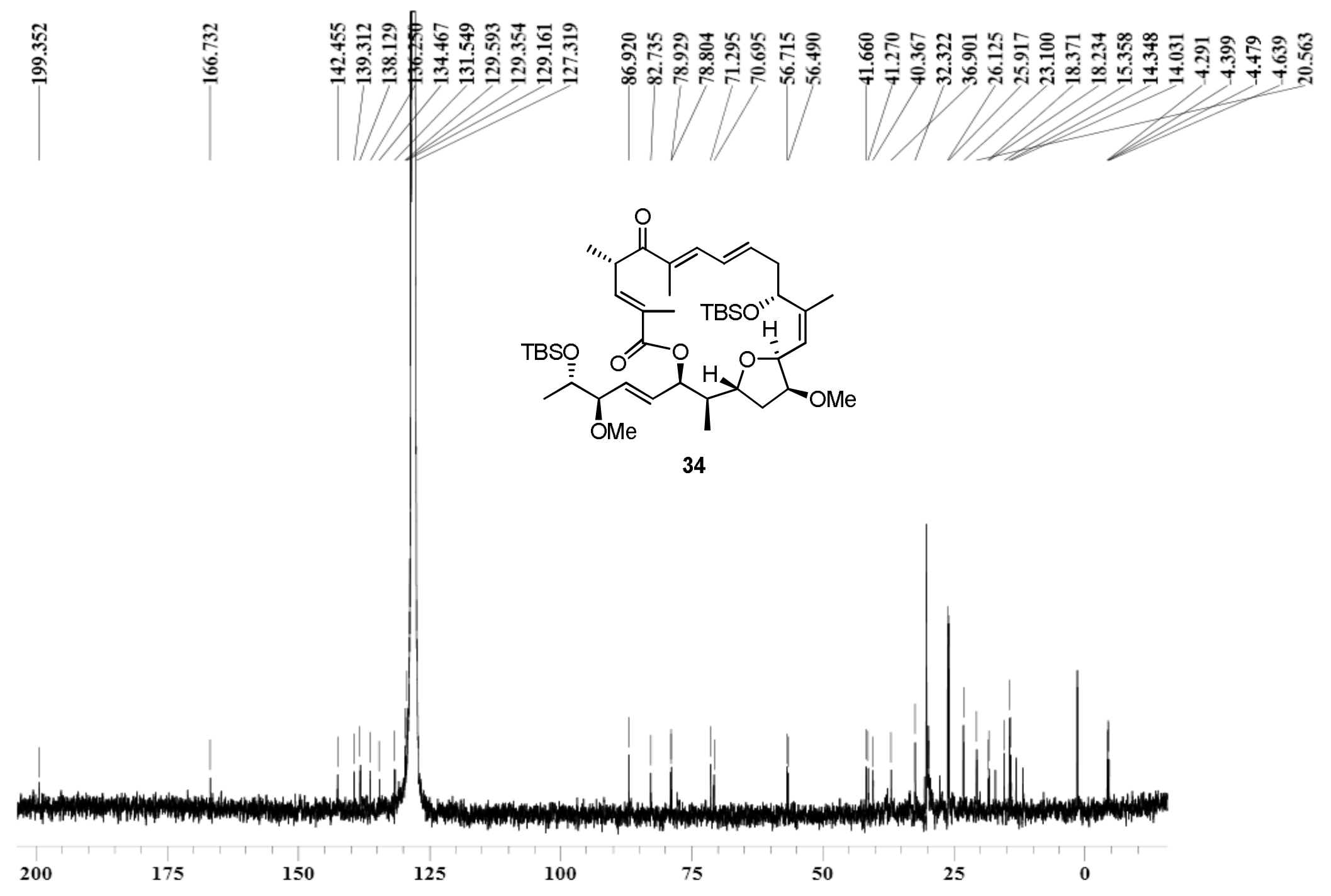

${ }^{13} \mathrm{C}$ NMR spectrum of 34 (Benzene-d $\mathrm{d}_{6}, 125 \mathrm{MHz}$ ) 
Maltepolid C, 3

$\mathrm{MeOH}-\mathrm{d} 4,300 \mathrm{MHz}$
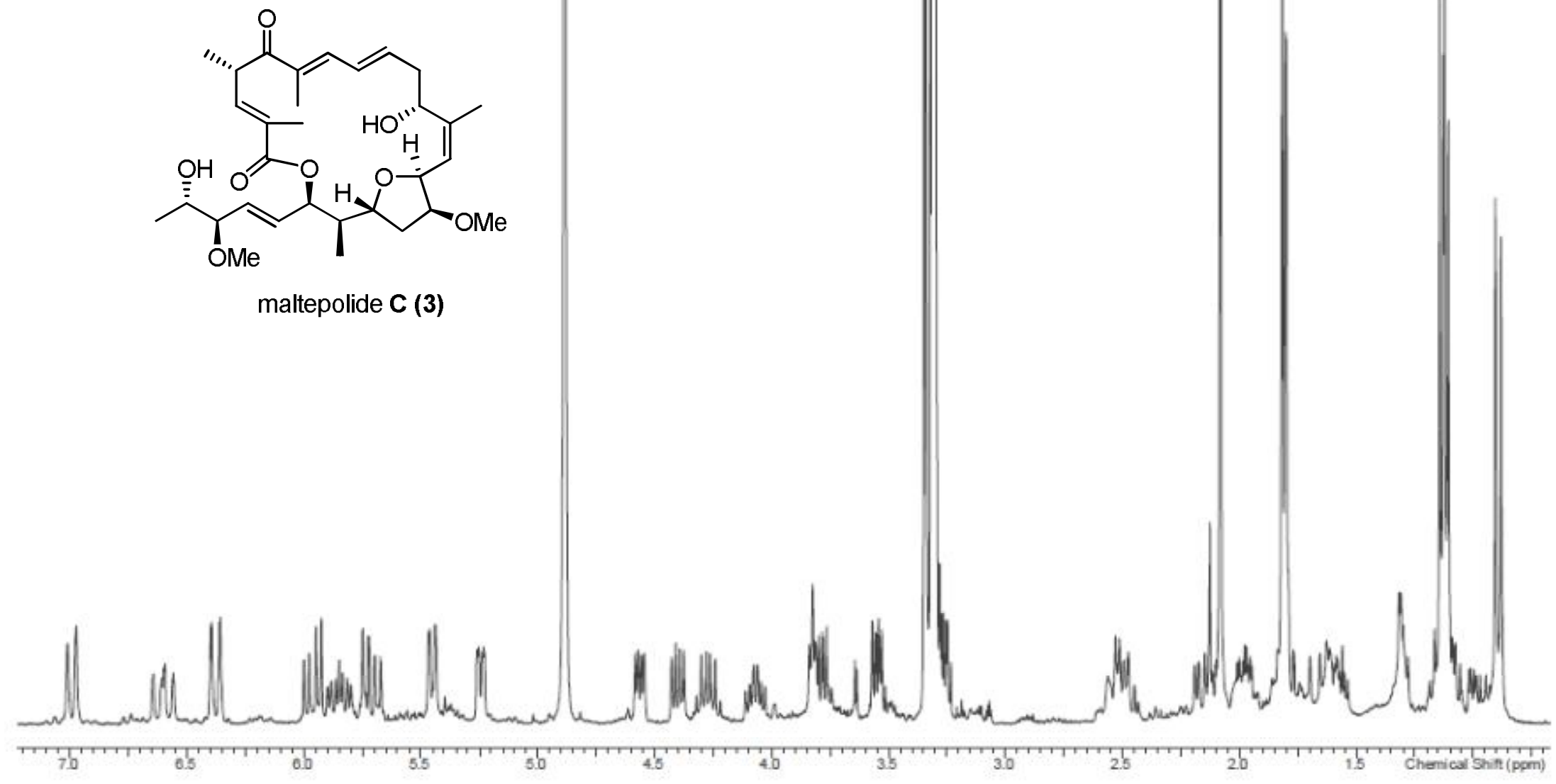

${ }^{1} \mathrm{H}$ NMR spectrum of maltepolide C (Isolation) (MeOH-d $4,300 \mathrm{MHz}$ ) 


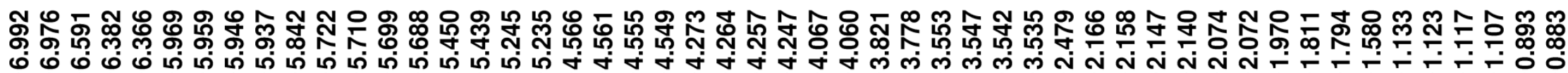

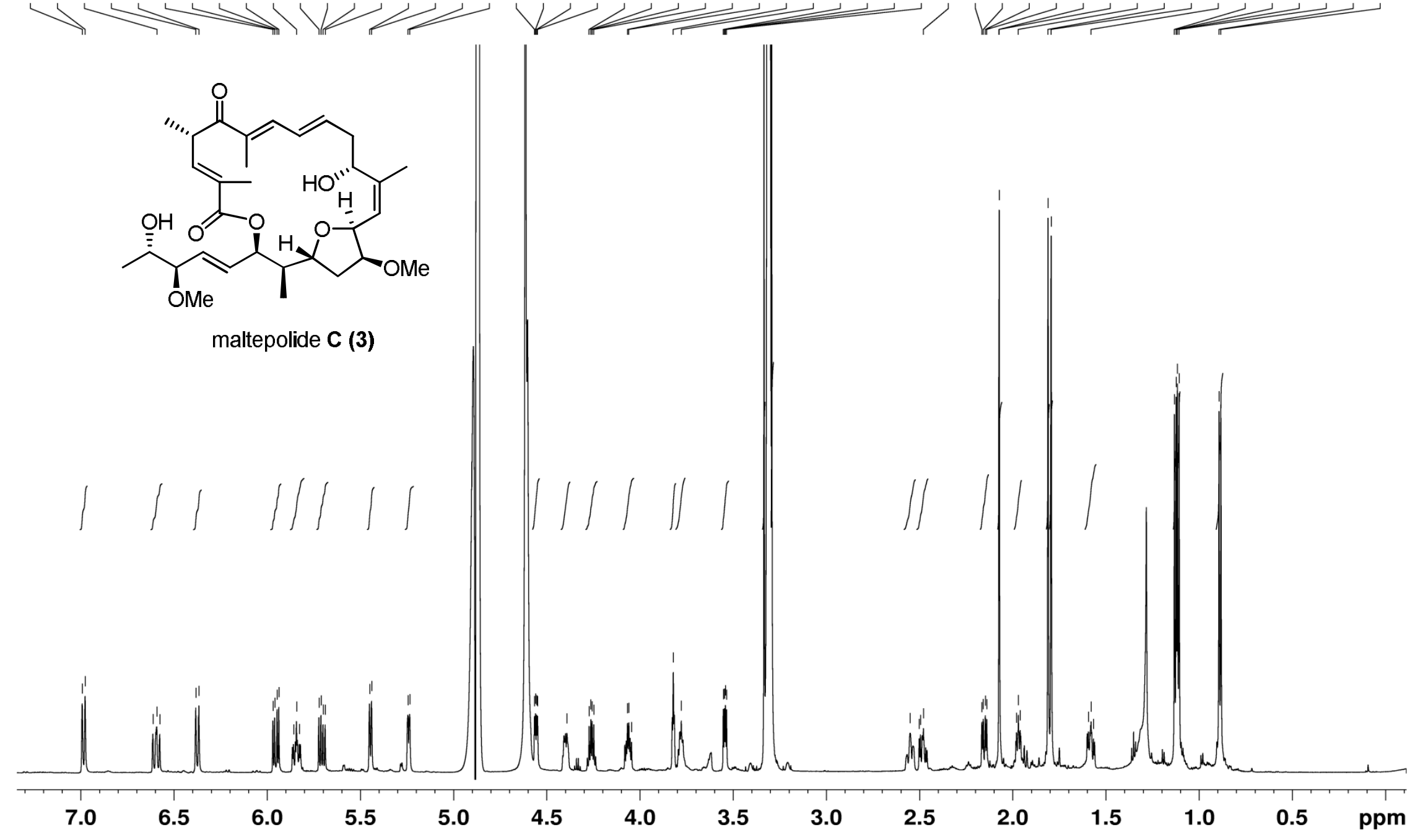

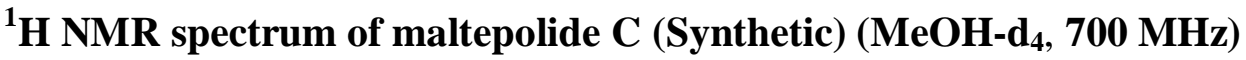



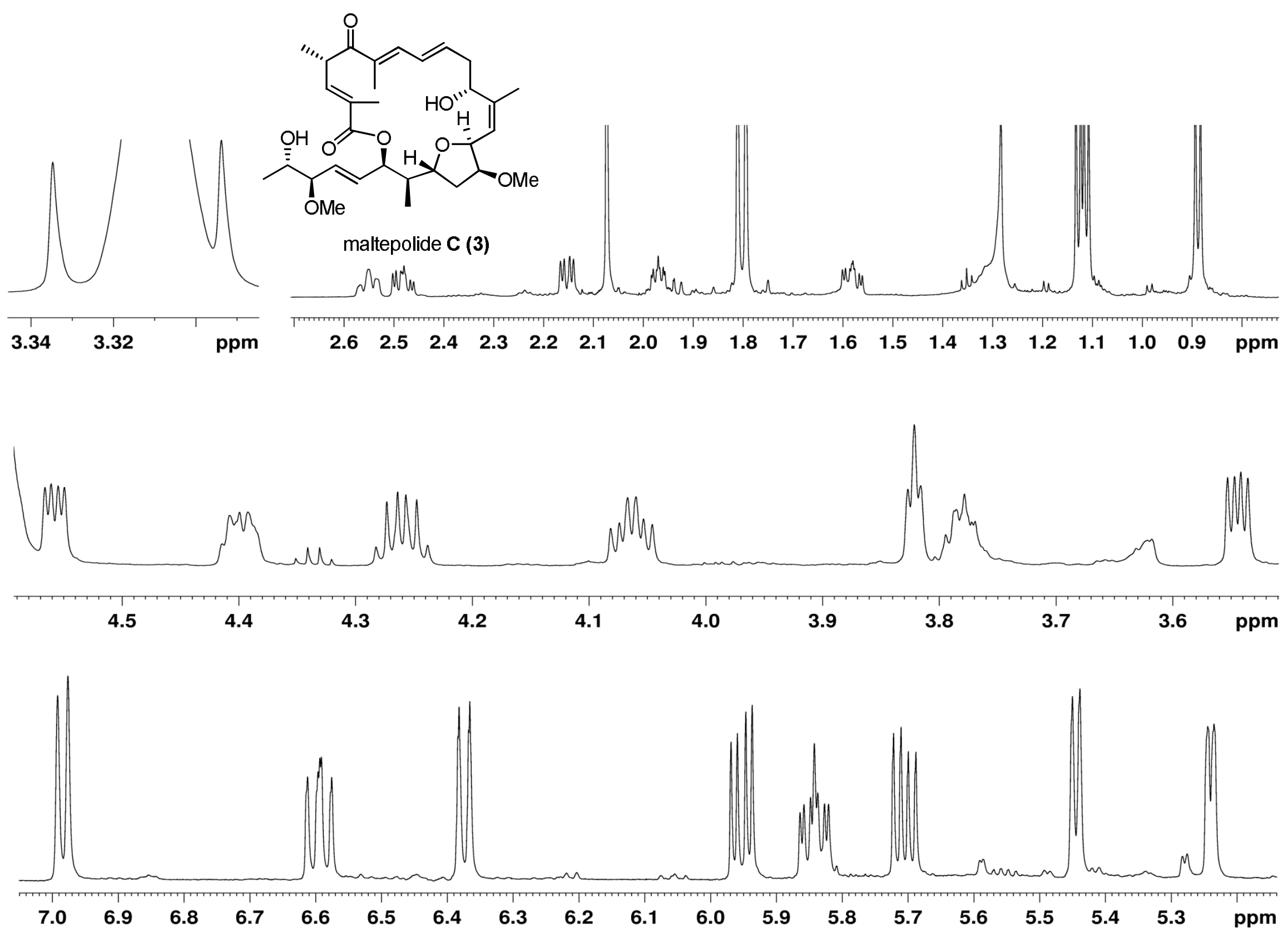

Expantion of ${ }^{1} \mathrm{H}$ NMR spectrum of maltepolide C (Synthetic) (MeOH-d 4 , $700 \mathrm{MHz}$ ) 
Maltepolid C, 3

$\mathrm{MeOH}-\mathrm{d} 4,125 \mathrm{MHz}$
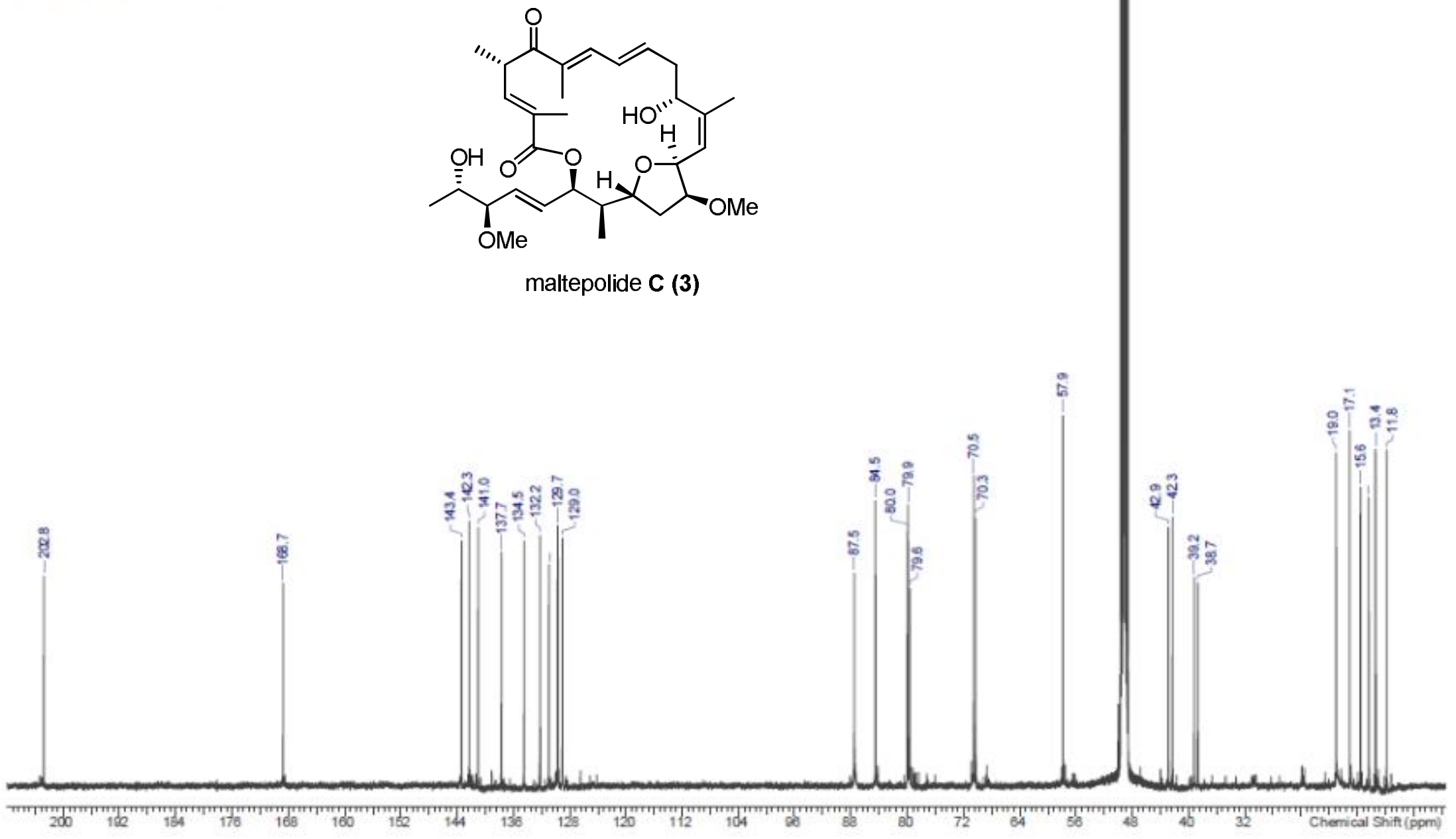

${ }^{13} \mathrm{C}$ NMR spectrum of maltepolide C (Isolation) (MeOH-d $4,125 \mathrm{MHz}$ ) 


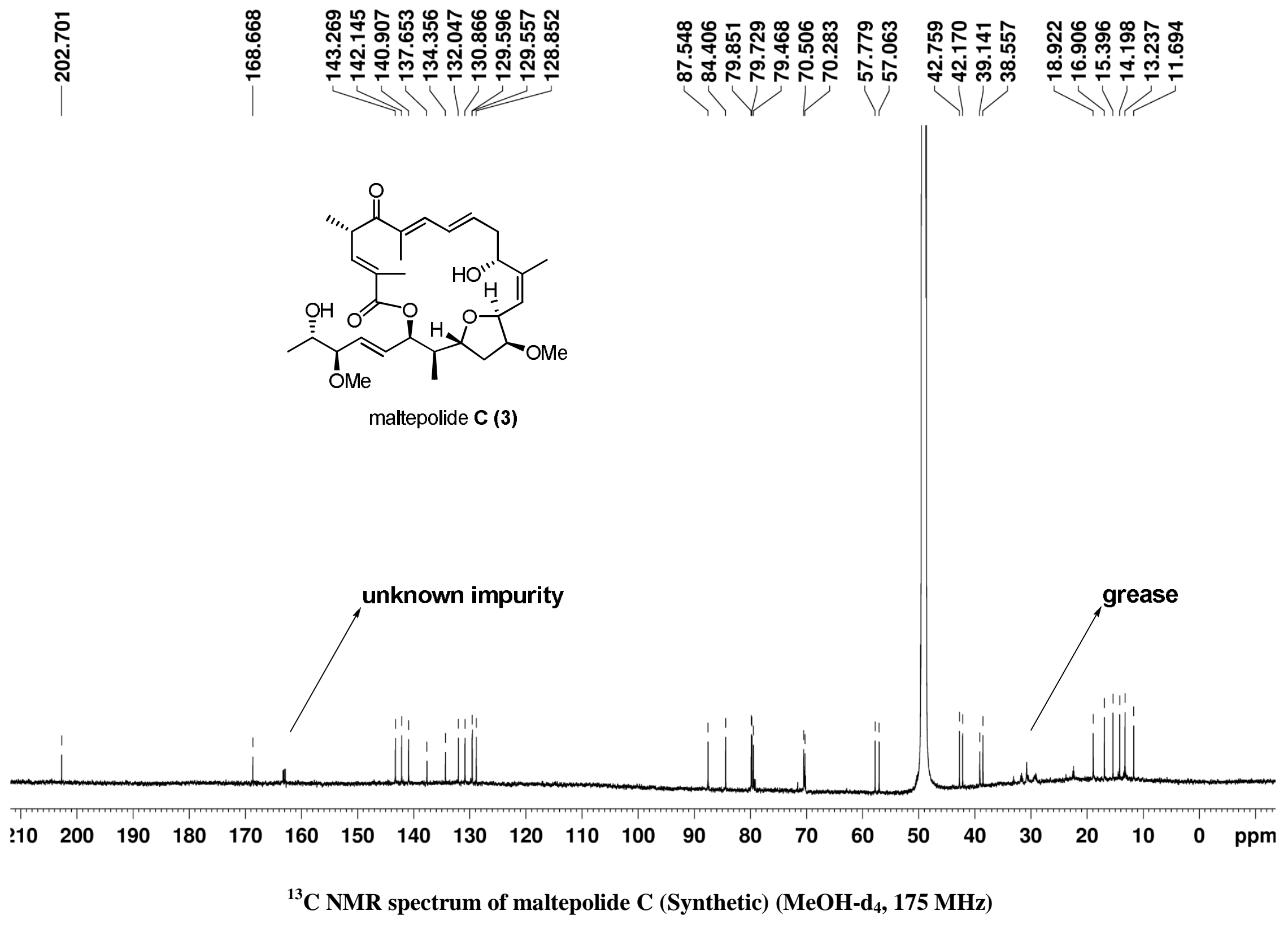




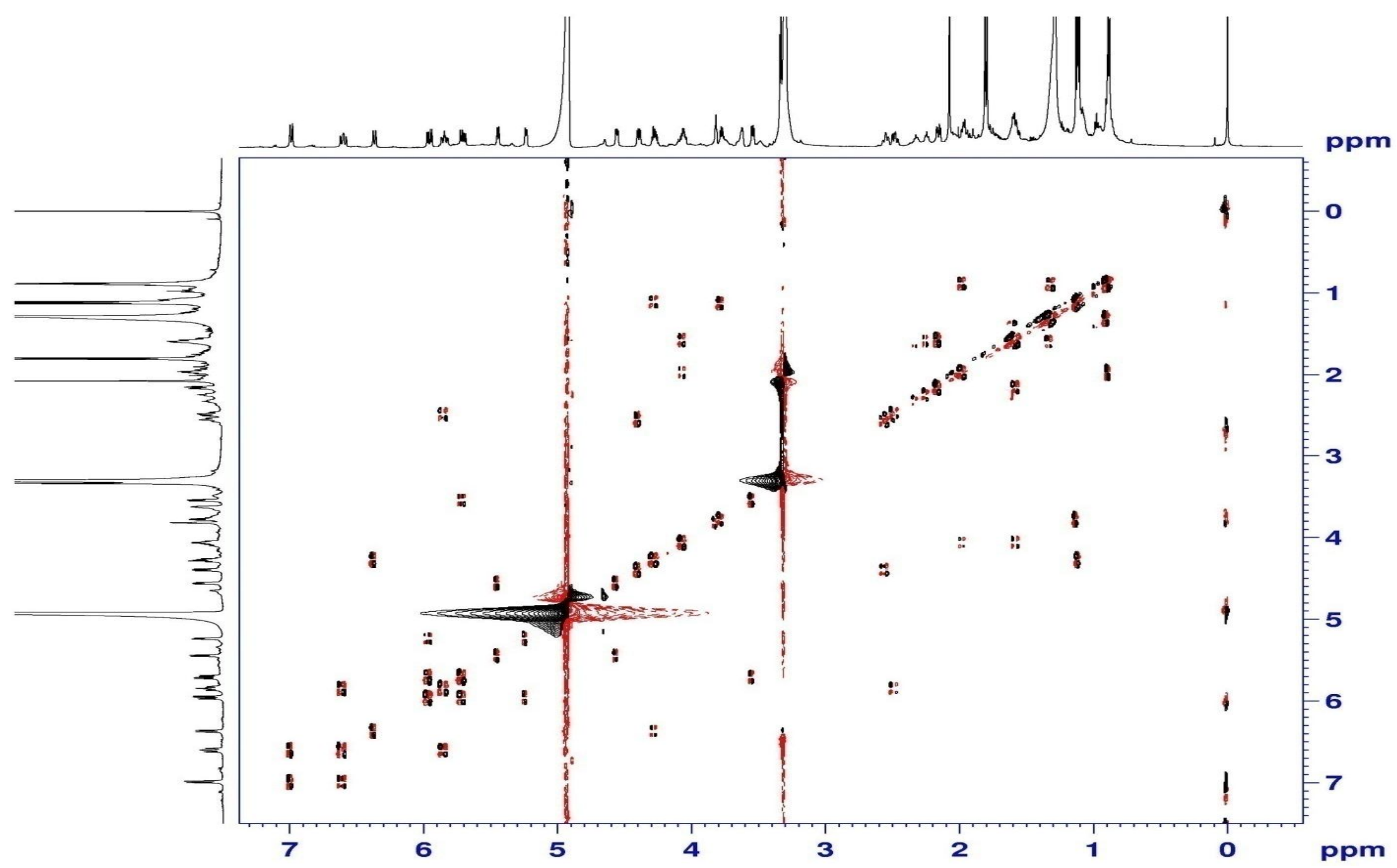

2D DQF-COSY (2D Double Quantum Filtered Correlation Spectroscopy) spectrum of compound 3 recorded on $600 \mathrm{MHz}$ at $25{ }^{\circ} \mathrm{C}$ in $\mathrm{MeOH}-\mathrm{d}_{4}$ 


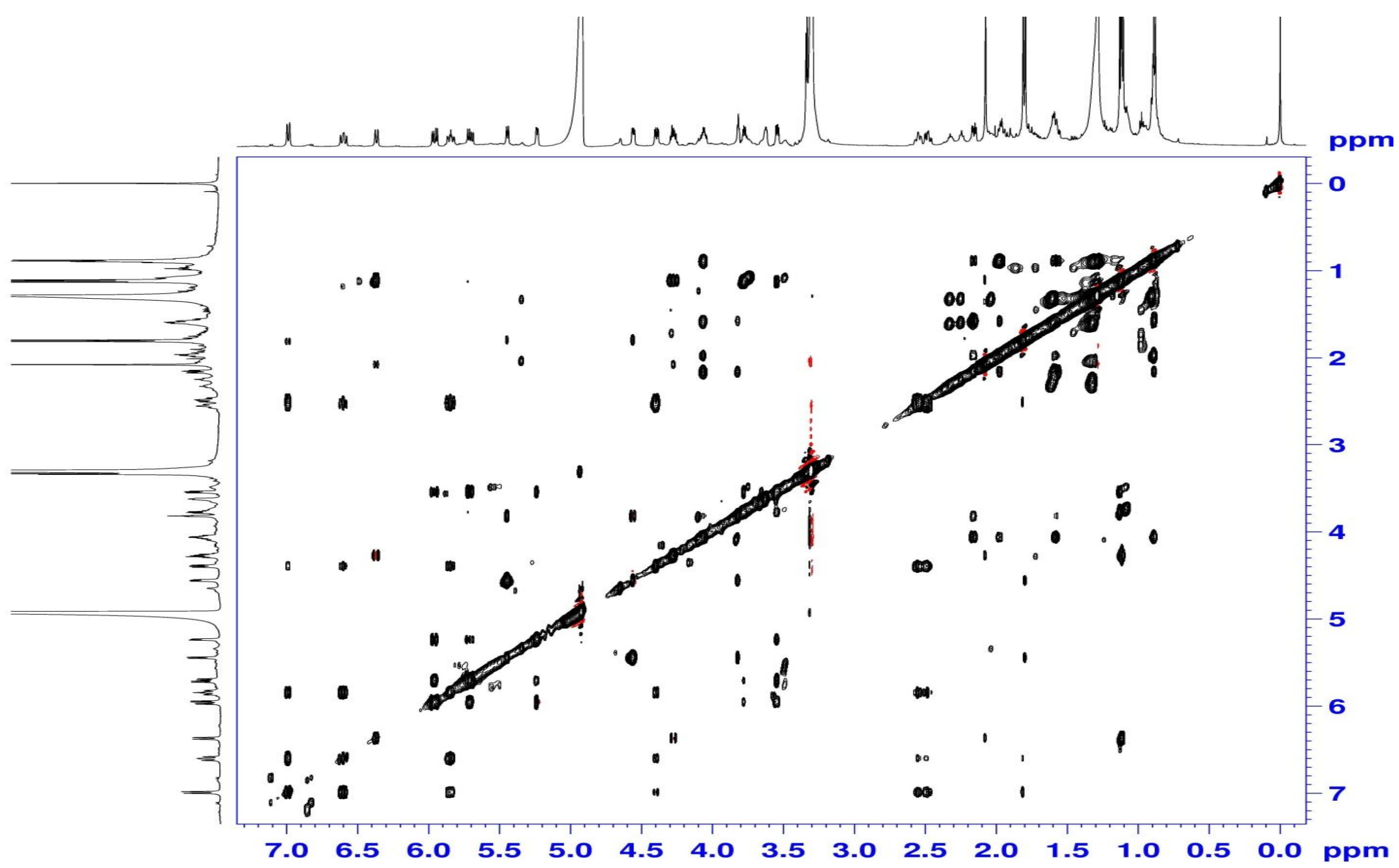

TOCSY (Total Correlation Spectroscopy) spectrum of compound 3 recorded on $600 \mathrm{MHz}$ at $25{ }^{\circ} \mathrm{C}$ in $\mathrm{MeOH}-\mathrm{d}_{4}$ 


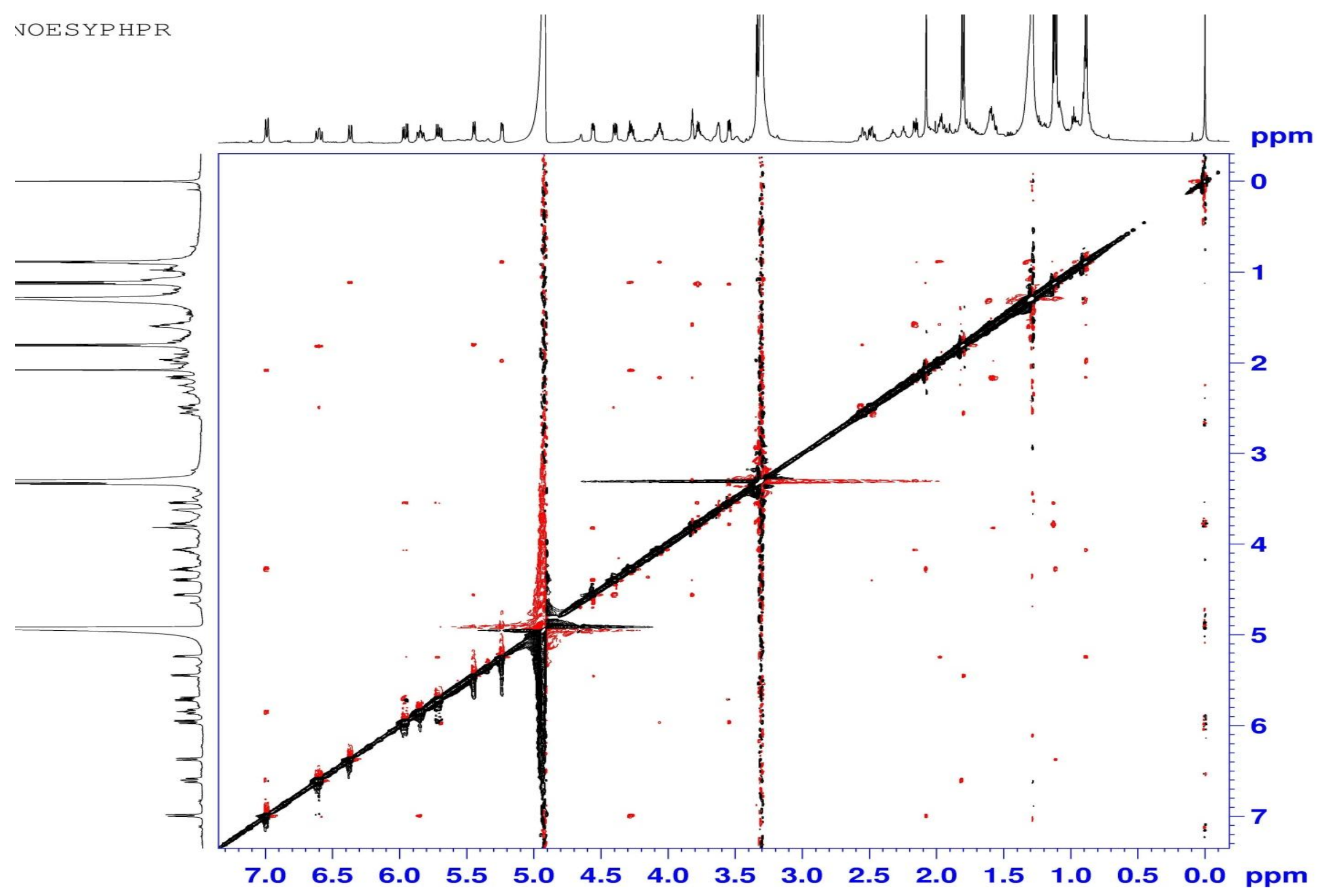

2D NOESY (Nuclear Overhauser Effect Spectroscopy) spectrum of compound 3 recorded on $600 \mathrm{MHz}^{\mathrm{at}} 25{ }^{\circ} \mathrm{C}$ in $\mathrm{MeOH}^{-\mathrm{d}_{4}}$ 


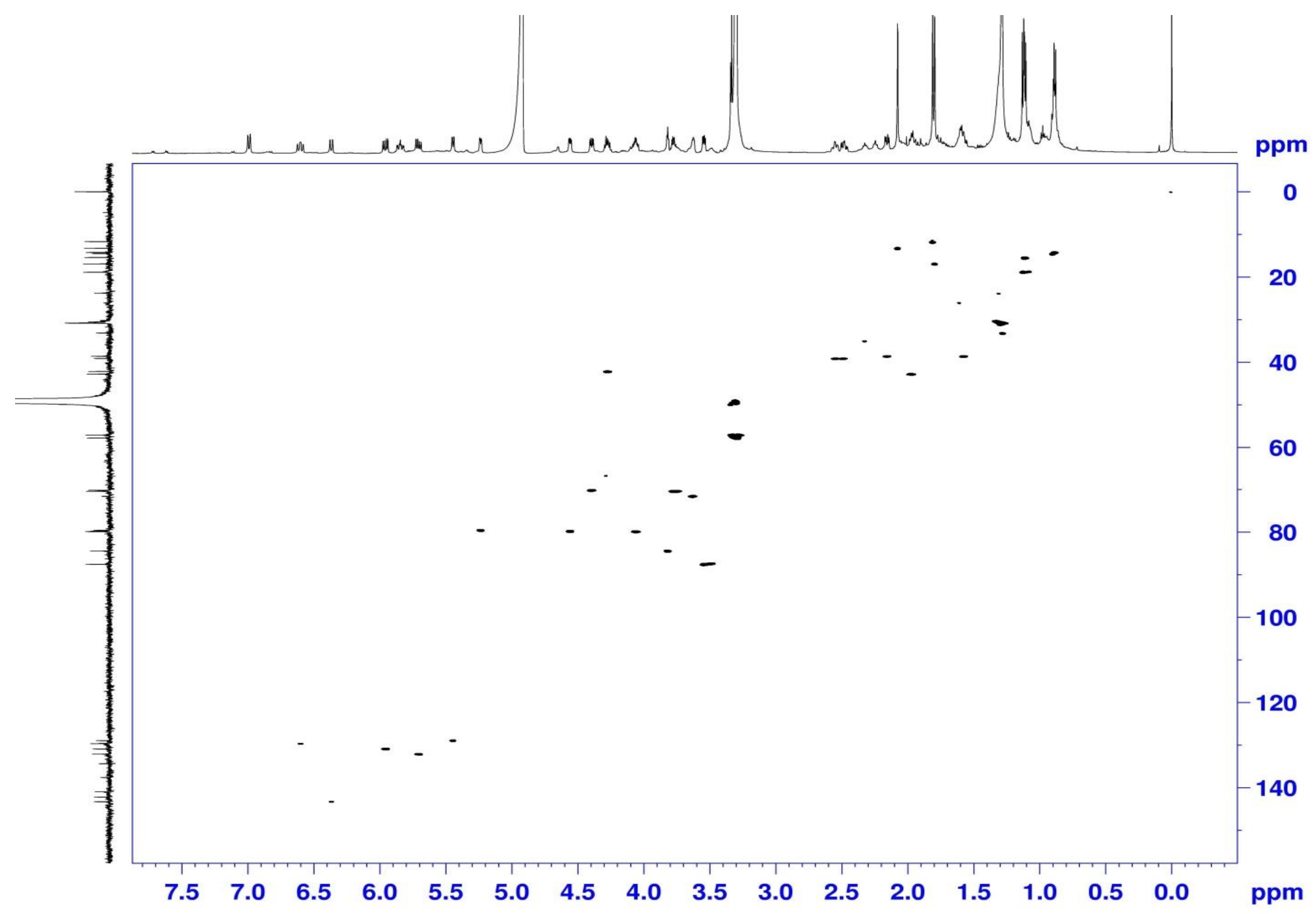

2D HSQC (Hetero-nuclear Single Quantum Correlation) spectrum of compound 3 recorded on $600 \mathrm{MHz}$ at $25{ }^{\circ} \mathrm{C}$ in $\mathrm{MeOH}-\mathrm{d}_{4}$ 


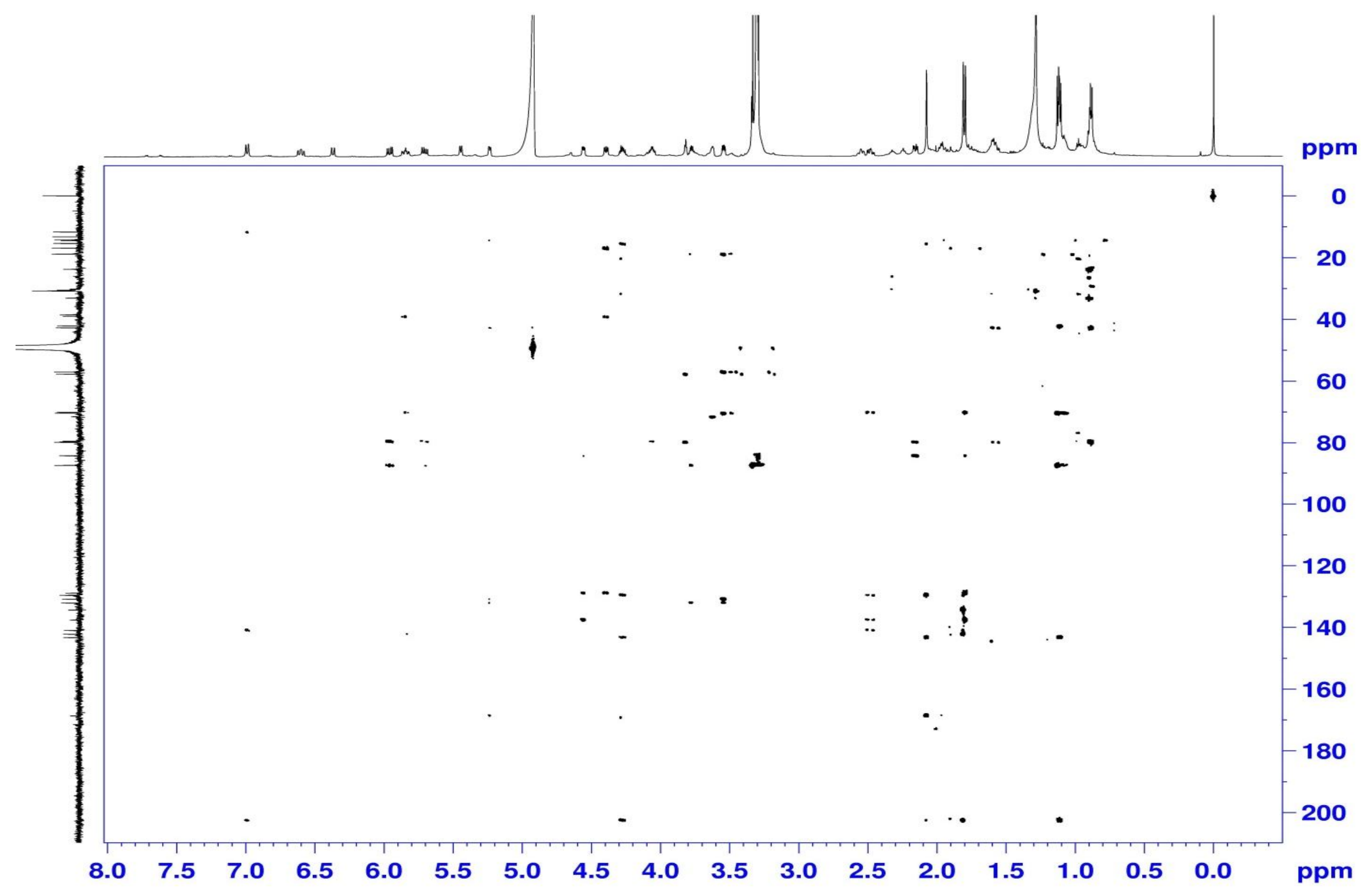

2D HMBC (Hetero-nuclear Multiple Bond Correlation) spectrum of compound 3 recorded on $600 \mathrm{MHz}^{\text {at }} 25{ }^{\circ} \mathrm{C}$ in $\mathrm{MeOH}-\mathrm{d}_{4}$ 